\title{
Projection of Needs for Gamma Radiation Sources and Other Radioisotopes and Assessment of Alternative for Providing Radiation Sources
}

June 1989

Prepared for the U.S. Department of Energy under Contract DE-AC06-76RLO 1830

Pacific Northwest Laboratory Operated for the U.S. Department of Energy by Battelle Memorial Institute 


\section{DISCLAIMER}

This program was prepared as an account of work sponsored by an agency of the United States Government. Neither the United States Government nor any agency thereof, nor Battelle Memorial Institute, nor any of their employees, makes any warranty, express or implied, or assumes any legal liability of responsibility for the accuracy, completeness, or usefulness of any information, apparatus, product, or process disclosed, or represents that its use would not intringe privateły owned rights. Reference herein to any specific commerical product, process, or service by trade name, trademark, manufacturer, or otherwise, does not necessarily constitute or imply its endorsement, recommendation, or favoring by the United States Government or any agency thereof, or Battelle Memorial Institute. The views and opinions of authors expressed herein do not necessarily state or reflect those of the United States Government or any agency thereof.

\section{PACIFIC NORTHWEST LABORATORY operated by \\ BATTELLE MEMORIAL INSTITUTE for the \\ UNITED STATES DEPARTMENT OF ENERGY under Contract DE-ACO6-76RLO 1830}

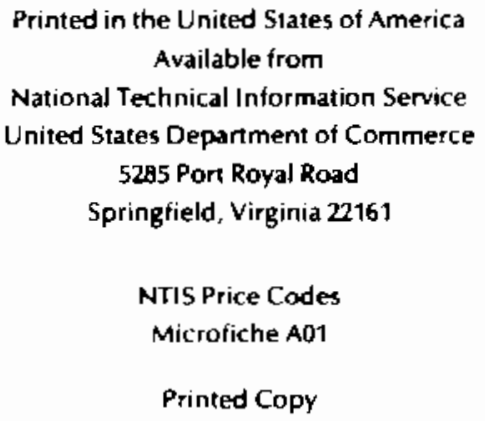

$\begin{array}{cc}\text { Pages } & \begin{array}{c}\text { Price } \\ \text { Codes } \\ 001-025\end{array} \\ 026-050 & \text { A02 } \\ 051-075 & \text { A03 } \\ 076-100 & \text { A04 } \\ 101-125 & \text { A05 } \\ 126-150 & \text { A06 } \\ 151-175 & \text { A07 } \\ 176-200 & \text { A08 } \\ 201-225 & \text { A09 } \\ 226-250 & \text { A10 } \\ 251-275 & \text { A11 } \\ 276-300 & \text { A12 } \\ & \text { A13 }\end{array}$


PROJECTION OF NEEDS FOR GAMMA RADIATION SOURCES AND OTHER RADIOISOTOPES AND ASSESSMENT OF ALTERNATIVES FOR PROVIDING RADIATION SOURCES
W. A. Ross
R. W. McKee
G. A. Jensen
L. G. Morgan
L. L. Clark
D. E. Eakin
S. M. Nealey
J. H. Jarrett
A. M. Platt
Y. B. Katayama
G. L. Tingey

June 1989

Prepared for the U.S. Department of Energy under Contract DE-AC06-76RLO 1830

Pacific Northwest Laboratory

Richland, Washington 99352 


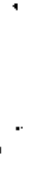

. 


\section{SUMMARY}

Pacific Northwest Laboratory reviewed the projected uses and demands for a variety of nuclear byproducts. Because the major large-scale near-term demand is for gamma irradiation sources, this report concentrates on the needs for gamma sources and evaluates the options for providing the needed material.

Projections of possible growth in the irradiation treatment industry indicate that there will be a need for 180 to $320 \mathrm{MCi}$ of ${ }^{60} \mathrm{Co}_{0}$ (including 137 Cs equivalent) in service in the year 2000 . The largest current and projected use of gamma irradiation is for the sterilization of medical devices and disposable medical supplies. Current1y, $40 \%$ of U.S. disposable medical products are treated by irradiation, and within 10 years it is expected that 90\% will be treated in this manner. Irradiation treatment of food for destruction of pathogens or parasites, disinfestation, or extension of allowable storage periods is estimated to require an active inventory of $75 \mathrm{MCi}$ of ${ }^{60}$ Co-equivalent gamma source in about a decade.

Currently, the primary supplier of gamma irradiation sources is Nordion International lnc. (formerly Atomic Energy Canada, Ltd.), which markets ${ }^{60} \mathrm{Co}_{0}$ produced in the operation of Canada's heavy-water-moderated (CANDU) commercial power reactors. Alternative sources evaluated include 1$){ }^{137}$ Cs from commercial spent fuel and defense wastes, 2) ${ }^{60} \mathrm{Co}$ from U.S. reactors, 3) direct use of spent fuel, and 4) radiation-generating equipment. Recovery of ${ }^{137} \mathrm{Cs}$ and other radioisotopes through reprocessing of spent fuel offers an adequate supply of gamma source material and also makes other byproducts available. The production of ${ }^{60} \mathrm{Co}$ in U.S. commercial reactors may become more likely should the economics of production become more attractive and the impact on the operating licenses of the facilities be manageable. Direct use of spent fuel provides a large potential supply but has the disadvantages of economic difficulties, safeguards problems, and potential public concern. The advantages of radiation-generating equipment are that machines are not dependent on byproduct availability, the radiation source stops when the machines are turned off, and the rate of application and penetration depth of 
the radiation dose is more flexible. Additional information and experience on machine reliability when operating for commercial irradiation sterilization or food treatment would be desirable.

The economics of utilizing byproducts are tied to the nuclear fuel cycle costs, particularly disposal costs. A preliminary cost comparison of waste treatment and disposal costs was prepared for four alternative systems. The systems evaluated are 1) direct disposal of consolidated spent fuel with no fuel recycle components/byproducts separation, 2) thermal outgassing of the spent fuel to remove volatile products before disposal, 3) reprocessing with low-cost financing and fuel recycle components/byproducts removal and utilization, and 4) reprocessing with high-cost financing and fuel recycle components/byproducts removal and utilization. Reprocessing with low-cost financing provides a potential saving of $\$ 315 / \mathrm{kg} U$ if all of the fuel recycle components/byproducts can be sold at their highest estimated value. However, if only the lowest value can be obtained, then low-cost financed reprocessing would increase the costs by $\$ 70 / \mathrm{kg} U$ when compared with direct spent-fuel disposal which is estimated to cost $\$ 260 / \mathbf{k g ~ U}$. The thermal outgassing alternative and the high-cost financed reprocessing alternative do not currently look economically attractive.

The potential demand for byproducts may exceed the expected supply of ${ }^{60} \mathrm{Co}$ from $\mathrm{AECL}$. Therefore, it is recommended that several alternative sources of garma radiation be considered. Alternatives that should be evaluated further include 1) reprocessing of commercial spent fuel with byproduct separation (if low-cost financing can be obtained), 2) radiationgenerating equipment, and 3 ) economic production of ${ }^{60} \mathrm{Co}$ in U.S. reactors. The direct use of spent fuel as the gamma source in an irradiator should also be evaluated further, but economic and institutional problems must be overcome.

Because of uncertainties with respect to economic and long-term-demand forecasts, it is recommended that additional economic and demand studies be periodically undertaken as the industry continues to grow. 


\section{CONTENTS}

SUMMARY

1.0 INTRODUCTION $\ldots \ldots \ldots \ldots \ldots \ldots \ldots$

2.0 CONCLUSIONS ...................... 2.1

3.0 CURRENT AND FUTURE NEEDS FOR GAMMA IRRADIATION SOURCES . . . . . 3.1

3.1 CURRENT USAGE AND NEAR-TERM GROWTH . . . . . . . . 3.1

3.2 POTEnTIAL MaRKETS . . . . . . . . . . . . . 3.2

3.2.1 Sterilization of Medical Products ........ 3.3

3.2.2 Treatment of Commercial Products . . . . . . 3.4

3.2.3 Treatment of Agricultural, Meat, and Fish Products ............... 3.4

3.2.4 0ther Potential Uses ........... . . . 3.10

3.3 DISPLACED PROOUCTS . . . . . . . . . . . . 3.12

3.3.1 Food Processing and Agriculture ......... 3.12

3.3.2 Medical Products Applications . . . . . . . . 3.12

4.0 PUBLIC ACCEPTANCE AND REgUlatoRY FACTORS . . . . . . . . 4.1

4.1 PUBliC ACCEPTANCE . . . . . . . . . . . . 4.1

4.1 .1 Perceived Benefits ............ 4.2

4.1.2 Risk of Disaster ........... 4.2

4.1 .3 Technology Control ........... 4.3

4.1.4 Basis of Opposition................ 4.4

4.2 REGULATORY FACTORS . . . . . . . . . . . . . . . 4.6

5.0 ALTERNATIVE SOURCES OF GAMMA RADIATION .......... 5.1

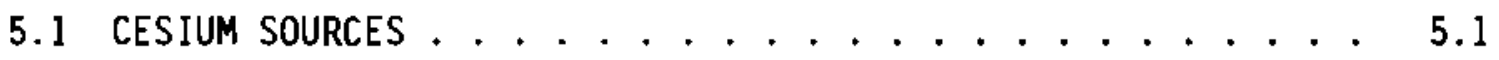

5.1.1 Recovery of Cesium and Other Radioisotopes

from Spent Fuel by Thermal Outgassing . . . . . . 5.5 


\subsubsection{Recovery of Cesium and Other Radioisotopes}

from Spent Fuel by Chemical Reprocessing . . . . 5.8

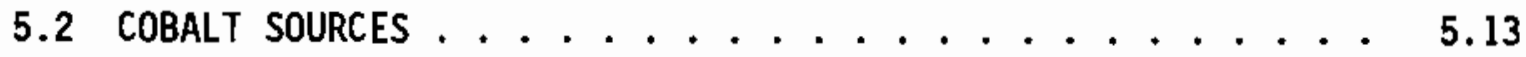

5.3 SPENT FUEL . . . . . . . . . . . . . . 5.14

5.4 RADIATION-GENERATING EqUIPMENT . . . . . . . . . . . 5.16

6.0 APPLICATIONS FOR BYPRODUCTS OTHER THAN GAMMA EMITTERS . . . . . 6.1

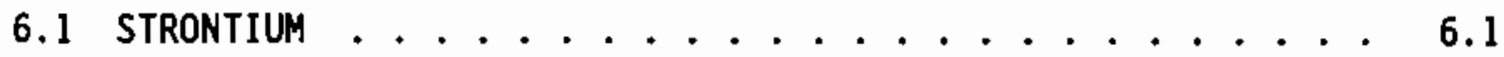

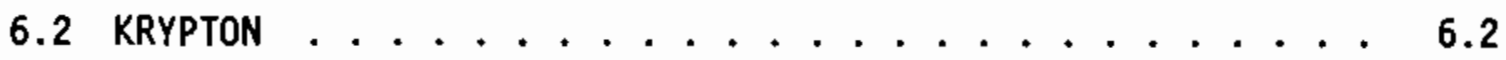

6.3 NOBLE METALS . . . . . . . . . . . . 6.3

6.4 OTHER ISOTOPES . . . . . . . . . . . . . 6.3

6.5 ESTIMATED USE OF BYPRODUCTS . . . . . . . . . 6.4

7.0 COST ANALYSIS AND ASSESSMENT OF ALTERNATIVES . . . . . . . 7.1

7.1 PROJECTION OF GAMMA SOURCES AND DEMANDS ......... 7.1

7.2 VALUE OF CESIUM FROM SPENT FUEL ............ 7.3

7.3 ECONOMIC COMPARISON OF BYPRODUCT SOURCES . . . . . . 7.3

7.4 COMPARISON OF THE MAJOR ALTERNATIVES . . . . . . . 7.9 REFERENCES . . . . . . . . . . . . . . . R. 1 APPENDIX A - AGRICULTURAL USES FOR IRRADIATION . . . . . . . A.I APPENDIX B - DEMONSTRATED APPLICATIONS OF RECOVERED SPENT FUEL ISOTOPES OTHER THAN CESIUM ................. B.I

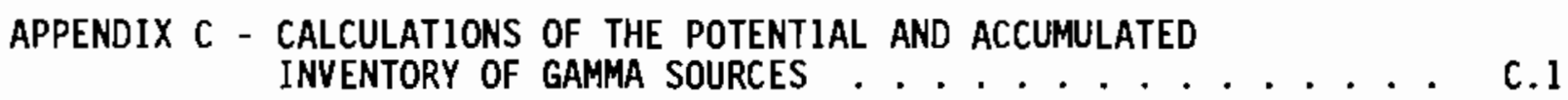




\section{FIGURES}

3.1 Comparison of Projected Gamma Needs for Food Irradiation . . . . 3.10

5.1 Flowsheet for Thermal Outgassing . . . . . . . . . . 5.6

5.2 Flowsheet for Chemical Processing . . . . . . . . . . 5.9

7.1 Comparison of Gamma Source Supply and Demand . . . . . . 7.2

A.l Algae for Feedstuff Production . . . . . . . . A.4

A.2 Transportable Irradiator . . . . . . . . . . A.7

B.1 Plutonium-Powered RTG . . . . . . . . . . . . B.21 


\section{IABLES}

3.1 Current Commercial Gamma Irradiators and Gamma Sources in the United States.................. 3.2

3.2 Possible Applications of Ionizing Radiation for the Treatment of Food .................... . . 3.5

3.3 Worldwide Food Products Currently Being Treated by Radiation . . 3.6

3.4 Gamma Use for Food Irradiation . . . . . . . . . . . 3.9

5.1 Comparison of Cobalt, Cesium, and Spent Fuel as Irradiation Sources . . . . . . . . . . . . . . . 5.2

5.2 Cesium Inventory in One Metric Ton of Commercial Spent Fue? With 32,700 Megawatt-Day Burnup 5 Years After Discharge . . . . 5.4

5.3 Estimated Inventories of Cesium-137 from Various Sources . . . 5.4

5.4 Flowsheet for Thermal Outgassing of 10-Year-01d Spent Fuel With 30,000 MWO/MTU Burnup ... . . . . . . . . . . . 5.7

5.5 Flowsheet for Chemical Processing of 10-Year-01d Spent Fue1 With 30,000 MWD/MTU Burnup ............. 5.10

5.6 Physical Characteristics of Typical Light Water Reactor Fuel Assemblies ..................... 5.16

6.1 Current and Potential Usage of Byproducts from Spent Fuel . . . 6.4

7.1 Cost Comparison of Spent Fuel Outgassing or Reprocessing Versus Spent Fuel Disposal in the United States . . . . . . 7.5

7.2 Costs for Byproduct Extraction . . . . . . . . . 7.6

7.3 Value of Uranium, Plutonium, and Fission Products in Spent Fuel ........................ 7.8

7.4 Assessment of Alternatives for Providing Gamma Irradiation . . 7.11

A.1 Selected Products Irradiated with Cobalt-60 Which Have Been Approved for Human Consumption . . . . . . . . . A.2

A.2 Trichina Survival Data at Varying Radiation Dosage . . . . . A.5

B.1 Recovery Criteria as Applied to Recoverable Isotopes or Elements 
B.2 Comparison of the Isotopic Concentration of Fission-Product and Atmospheric Krypton . . . . . . . . . . . . B.3

B.3 Isotopic Comparison of Fission-Product and Atmospheric

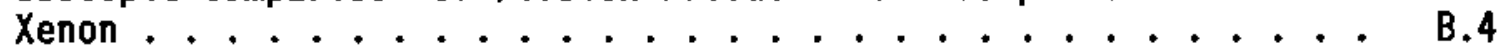

B.4 Possible Isotopes for Self-Powered Illuminators and Their Relevant Properties............... B.6

C.1 Predicted Gamma Source Inventory with Minimum Production . . . C.2

C.2 Predicted Gamma Source Inventory in the United States with Maximum Production ............. c.3

C.3 Predicted Gamma Source Inventory with Maximum Development of Resources and no Imports after $1999 \ldots \ldots . . \ldots$. . . . .

C.4 Predicted ${ }^{60}$ Co Gamma Source Required for Medical and Food Treatment . . . . . . . . . . . . . . . 0.5 


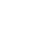




\subsection{INTRODUCTION}

Nuclear byproducts have a variety of current and potential uses. The primary objectives of this study are to identify potential needs for byproduct materials, with a focus on irradiation sources, and to determine the technical feasibility and costs of various alternative methods of supplying gamma source materiais and other products.

This work was sponsored by the Department of Energy, Office of Nuciear Energy, and this report has been prepared by Pacific Northwest Laboratory as part of the Advanced Radiation Technology Program.

The report discusses current and potential applications for gamma sources in treatment of agricultural and commercial products in Section 3.0. Section 4.0 describes the public acceptance and regulatory factors which may impact application of the technology. Section 5.0 provides information on the alternative sources of gamma radiation, including sources that are competitors to spent fuel byproducts. Current and potential applications for byproducts other than cesium are described in Section 6.0. An assessment that includes cost factors is presented in Section 7.0. Detajls of specific topics are described in the appendices.

This study is intended to give a broad overview and should be followed by specific detailed studies on the most attractive options identified by this review and analysis. 



\subsection{CONCLUSIONS}

As a result of this study, several conclusions were reached:

- The near-term demand for irradiation sources will continue to increase. Utilization of gamma sources could reach $110 \mathrm{MCi}$ of cobalt equivalent by 1990 , based on information supplied by commercial irradiators. Demand for gamma sources should continue to grow throughout the 1990s.

- Five major U.S. sources of gamma radiation were evaluated (thermal outgassing of spent fuel, chemical processing of spent fuel, direct use of spent fuel, production of cobalt in comnercial and DOE reactors, and machine-generated radiation). The last two are the most promising for the near term. Chemical processing of spent fuel is also a possibility but will require major new facilities before it could be utilized.

- The importing of cobalt from Canada will likely continue and grow in magnitude.

- Existing and future commercial spent nuclear fuel will contain sufficient cesium to meet the estimated needs.

- Chemical reprocessing of spent fuel appears to be significantly more economical than thermal outgassing of spent fue1.

- Depending on fuel recycle components/byproducts values and assuming a market, a low-return financing of reprocessing of commercial spent fuel could result in cost savings of up to $\$ 315 / \mathrm{kg} U$ when compared to direct spent fuel disposal. Reprocessing is less favorable for high-return financing and could result in an additional cost of $\$ 190$ to $\$ 575 / \mathrm{kg} \mathrm{U}$. (These ranges are due to the uncertainty in value and marketability of the recovered fuel recycle components/byproducts.)

- Annual production of 1 to $8 \mathrm{MCi}$ of ${ }^{60} \mathrm{Co}$ may be possible in the presentTy shut-down Hanford $\mathrm{N}$-Reactor and may be advantageous to reactor operation should the reactor be restarted. Cobalt production in the Fast Flux Test Facility (FFTF) is also possible at the severat MCi per year level. 


\subsection{CURRENT AND FUTURE NEEDS FOR GAMMA IRRADIATION SOURCES}

This chapter discusses the current and potential markets for irradiation sources and the potential replacement of other products by irradiation treatment.

The market for irradiation treatment has been anticipated for many years (Overbeek 1966) and may now finally be realizing some of its potential. The major potential growth areas appear to be those where the chemicals that have been used are coming under closer regulatory control because of toxicity problems that were not previously known. Gamma irradiation of materials leaves no residue. Minor chemical changes occur from radiolysis, but these changes have been thoroughly examined by the Food and Drug Administration and no detrimental health effects have been observed (U.S. Department of Health and human Services 1986, 1988).

\subsection{CURRENT USAGE AND NEAR-TERM GROWTH}

During November 1986, a survey was conducted on the current U.S. commercial use of irradiation sources to obtain current estimates of near-term U.S. needs for irradiation sources. Sixteen companies with a total of 42 commercial-scale irradiators were identified and contacted. All companies provided the requested information. Additional details on the companies are available in the current literature (Gidwani 1986; AECL 1986a,b). Table 3.1 shows that the current commerciat use inventory of ${ }^{60} \mathrm{CO}_{0}$ is near $62 \mathrm{MC} i$ and the ${ }^{137} \mathrm{Cs}$ inventory is $16 \mathrm{MCi}$. Only one irradiator is totally based on ${ }^{137} \mathrm{Cs}$, but up to four additional irradiators have mixed sources. For the Hanford Waste Encapsulation and Storage Facility Capsules, (a) 7 cesium curies are equal to 1 cobalt curie, and the total commercial cesium inventory is equivalent to about $2 \mathrm{MC} i$ of cobalt. This gives a total commercial use inventory equivalent to about $64 \mathrm{MCi}$ of cobalt. An additional $67 \mathrm{MC} i$ of ${ }^{60} \mathrm{Co}$ is projected to be needed by commercial irradiators by the end of 1990 for growth and replacement.

(a) The majority of the cesium from the underground storage tanks of defense high-level waste at Hanford has been removed, processed into cesium chloride, and placed in doubly-sealed capsules in the Waste Encapsulation and Storage Facility (WESF) at Hanford, Washington (Jackson 1976). 
IABLE 3.1. Current Commercial Gamma Irradiators and Gasma Sources in the United States

Number of Total ${ }^{60} \mathrm{Co}$ Total ${ }^{137} \mathrm{Cs}$ Estimated Additional Total Demand lrradiators Inventory. $M C i$ Inventory, $M C i$ for ${ }^{60} C_{0}$ Through End of 1990, MCi

42

62

16

67

The results of this survey indicate that the U.S. irradiation industry has more than doubled in the past 5 years, based on a previous study (NUS 1981) that indicated a total commercial and research use inventory of $32 \mathrm{MCi}$ of ${ }^{60} \mathrm{Co}$ and $2 \mathrm{MCi}$ of ${ }^{137} \mathrm{Cs}$, giving a growth rate of over $16 \% / \mathrm{yr}$. The survey taken in November 1986 for this report indicates that the industry will continue to grow at a compound rate of about 13\% annually, resulting in a 1990 inventory of about $110 \mathrm{MCi}$ of cobalt (including cesium equivalent) in commercial service. This amount implies a need for about $17 \mathrm{MCi}$ of cobalt each year to account for decay and to supply the growth.

There are a large number of research and development irradiators throughout the country. No growth in the number of these facilities was considered. Neither was growth in ${ }^{60} \mathrm{Co}$ use in cancer radiation treatment considered, because most of the demand for cancer therapy is now for machine-generated radiation.

\subsection{POTENT1AL MARKETS}

Existing and potential applications of gamma irradiation include sterilization of medical products, commercial products, treatment of foods, clinical treatment, and chemical synthesis. Although several isotopes and radiationgenerating equipment have been used in special applications, most existing commercial installations use ${ }^{60} \mathrm{Co}_{0}$ as the gamma source. Cesium-137, a byproduct from the nuclear fuel cycle, has also been shown to meet the requirements as a radiation source.

The following subsections describe the major existing and potential applications and markets for irradiation sources. 


\subsubsection{Sterilization of Medical Products}

By far the largest single industrial use of irradiation is the sterilization of medical devices and disposable medical supplies. Today about $40 \%$ of the disposable medical supplies used in the U.S. are sterilized by this process. The growth of irradiation sterilization has been rapid during the past 7 years. Previously, medical products were sterilized by fumigation using ethylene oxide (ETO). However, in 1977 the Environmental Protection Agency (EPA) published the results of toxicity tests that indicated that ETO

was mutagenic. Tests by industry and regulatory agencies also suggested that it was a carcinogen. The Occupational Safety and Health Administration (OSHA) has subsequently changed their regulations decreasing the allowable integrated daily exposure level from $50 \mathrm{ppm}$ of ETO to $0.5 \mathrm{pm}$ in air. This major reduction in allowable exposure is very expensive to implement. Therefore, the medical supply industry has conducted studies of alternatives and has determined that radiation is an attractive option.

Sterilization of products by radiation is an aimost ideal process. Products can be manufactured and packaged first and then sterilized while inside sealed packages, which prevents recontamination following sterilization. Although a similar process is used for fumigation, radiation sterilization offers much greater selection of packaging materials.

In the medical supply industry, ionizing energy for sterilization has been supplied by both electron-beam-generating machinery and by gamma radiation. Electron beam processing, with its lower penetration and high dose rate, can (depending on the energy of the beam and the product density) irradiate two sides of products that have typical thicknesses of 10 to $40 \mathrm{~cm}$. In contrast, gamma radiation has much greater penetration, which allows the treatment of whole pallets and boxes of medical supplies. The gamma irradiation process is less subject to dose variations.

Irradiation sterilization of medical products is expected to increase, with about $90 \%$ of the potential medical products market treated by radiation within a decade. With continued $5 \%$ per year growth of the medical products industry and treatment of $90 \%$ of the products by about 1997, an inventory of $195 \mathrm{MCi}$ of ${ }^{60} \mathrm{Co}$ will be needed for the treatment of medical products. 


\subsubsection{Ireatment of Commercia] Products}

The demands for sterile products for end use and for product packaging are creating a need for treatment of commercial products. Some items that are currently sterilized for the commercial market include cotton balls, feminine hygiene products, milk and ice cream cartons, baby bottle nipples, and teething rings. Obviously, other products also require sterilization. These types of products are currently producing about 7 to $8 \%$ of the sterilization revenue for commercial irradiation service companies (Gidwani 1986). This market can also grow as it becomes more difficult to use chemical sterilizers and as people become more aware of the advantages and services of irradiation companies. The growth of commercial product treatment was not evaluated separately from that of medical products because such products are treated in similar facilities and because survey data for the two were mixed. Therefore, a separate estimate of future need was not obtained.

\subsubsection{Treatment of Agricultural, Meat, and Fish Products}

A wide variety of agricultural, meat and fish products can be treated beneficially by radiation (Josephson 1982, Moy 1983, Molton 1987). A summary of some potential applications is shown in Table 3.2. The types of treatment are classified by the average dose required.

Major objectives in irradiating agricultural, meat and fish products are destruction or reduction of particular organisms, parasites, insects, mold, yeast, and microbes, which are all affected differently by radiation doses.

Table 3.3 lists many of the products that are currently being treated by radiation in various countries. Details of the treatment methods are discussed in Appendix A. Many of these products are not currently treated by radiation in the U.S., but with the FDA approval of 21 CFR 179, "Irradiation in the Production, Processing, and Handling of Food" (U.S. Department of Health and Human Services 1986, 1988) increasing quantities and types of products will likely be treated. Treatment of pork, fresh fruits and vegetables, and spices is now permitted.

Radiation treatment is becoming more attractive as concerns increase about the use of certain chemicals (e.g., ethylene dibromide, methyl bromide, and ethylene oxide) for fumigation of food. Irradiation may become the 


\section{IABLE 3.2. Possible Applications of Ionizing Radiation for the Treatment of Food $(a)$}

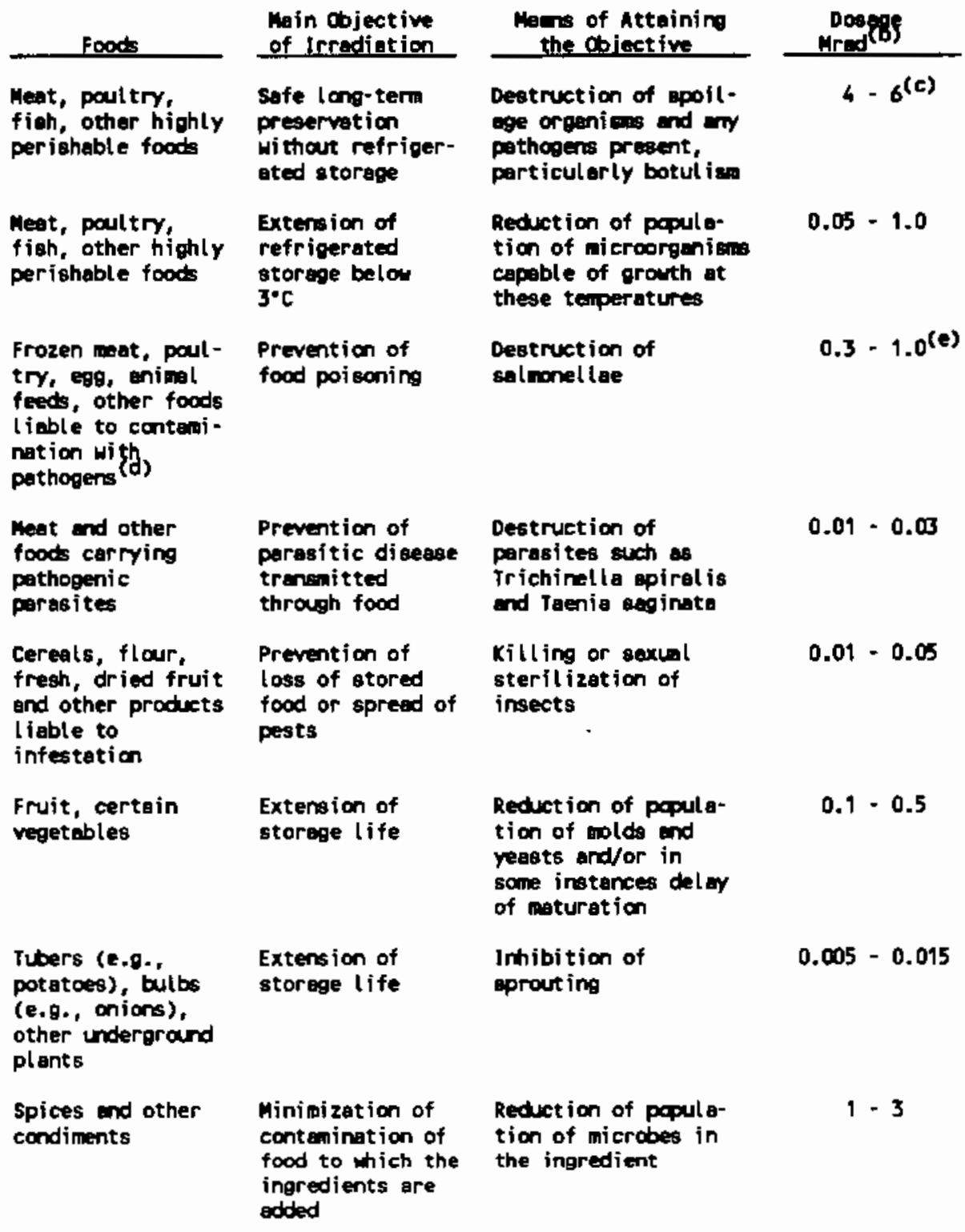

(a) This teble was originally publ ished as pert of World Health Organization Technical Report Series No. 315(3).

(b) $1 \mathrm{Mrad}=10 \mathrm{kGy}$ (Gray) $=10$ Joule $/ \mathrm{kg}$.

(c) A lower dose might suffice for certain cured products.

(d) Including animal feeds.

(e) A higher dose may be needed if pathogens with greater resistence to radiation are present. 
IABLE 3.3. Horldwide Food Products Currently Being Treated by Radiation(a)

\begin{tabular}{|c|c|c|c|c|}
\hline Disinfestation & $\begin{array}{c}\text { Sprout } \\
\text { Inhibition }\end{array}$ & $\begin{array}{l}\text { Delay of } \\
\text { Spoilage }\end{array}$ & $\begin{array}{l}\text { Elimination } \\
\text { of Pathogens }\end{array}$ & Sterilization \\
\hline $\begin{array}{l}\text { Wheat } \\
\text { Flour } \\
\text { Rice } \\
\text { Other grains } \\
\text { Cherries } \\
\text { Apples } \\
\text { Cocoa beans } \\
\text { Spices } \\
\text { Dried fruits }\end{array}$ & $\begin{array}{l}\text { Onions } \\
\text { Garlic } \\
\text { Shallots } \\
\text { Potatoes } \\
\text { Mushrooms }\end{array}$ & $\begin{array}{l}\text { Strawberries } \\
\text { Tomatoes } \\
\text { Peaches } \\
\text { Apricots } \\
\text { Cherries } \\
\text { Raspberries } \\
\text { Asparagus } \\
\text { Papayas } \\
\text { Mangos } \\
\text { Avocados } \\
\text { Shrimp } \\
\text { Rabbit } \\
\text { Cod } \\
\text { Haddock } \\
\text { Whiting }\end{array}$ & $\begin{array}{l}\text { Shrimp } \\
\text { Chicken } \\
\text { Pork } \\
\text { Frog legs }\end{array}$ & $\begin{array}{l}\text { Frozen meats } \\
\text { Food for special } \\
\text { medical diets }\end{array}$ \\
\hline
\end{tabular}

(a) Source: Josephson and Peterson 1982 pp. 8-13.

preferred treatment for disinfestation, and in many applications, for preservation. Research has shown that doses of less than $30 \mathrm{krad}$ will effectively disinfest citrus fruit of Caribbean fruit fly, apples of codling moth, pork of parasitic nematode (trichina spiralis), and cherries of cherry fruit fly. It appears that irradiation may be useful in the treatment of many other agricultural products, field crops and foods as we11. For some of these products, the dose required and the possible secondary effects need further evaluation and, in some cases, need to be tested at harvest, packing, or processing sites. A transportable demonstration ${ }^{137} \mathrm{Cs}$ irradiator has been built, and work is proceeding to evaluate irradiation of fruits, nuts, pork (U.S. DOE 1986), cattle hides and other agricultural commodities ("Food lrradiation Technology in the United States" 1982).

The use of food irradiation as a conservation measure is particularly applicable to the problem of world hunger. The U.S. Agency for International Development (A1D), in conjunction with DOE and the World Health Organization (WHO), is investigating this technology to reduce food loss and improve its nutritive value, issues that are potentially significant in developing countries. 
Actions by the joint FAO/IAEA/WHO(a) Expert Committee on Wholesomeness of Irradiated Food concluded (WhO 1981) that sufficient data exist to show that irradiation could be used safely at doses less than 1 Mrad for treatment of food. The Council for Agricultural Science and Technology concluded that irradiated foods compare favorably with fresh foods or with foods processed by well-established conventional methods, and that they are safe to eat (CAST 1986). A review of food irradiation by the Advisory Comnittee on Irradiated and Novel Foods for the Department of Health and Social Security in the UK reviewed the literature and stated "that the irradiation of food up to an overall average dose of $10 \mathrm{kGy}$ presents no toxicological hazard and introduces no special nutritional or microbiological problems" (Ministry of Agriculture, Fisheries, and Food 1986). The report recommended that food irradiation be allowed in the United Kingdom. Thus, increased use of irradiation as a means of disinfesting, preserving, and improving quality of food in the U.S, and other countries can be expected.

The projection of gamma source material requirements for the treatment of food is very tenuous because the commercial industry is so new and the acceptance of irradiated food by the public is still uncertain. However, a review of the literature, interviews with industrial contacts, and engineering judgment have been used in estimating future requirements. The estimation process uses five major factors to estimate the gamma requirement. First, the products that could likely benefit from radiation treatment were selected from Table 3.3 and other sources. Second, the quantities of products recently produced in the U.S. were obtained from U.S. agricultural statistics for 1984, when available, and for other recent years when they were not avajlable for 1984 . The third factor is the dose required to treat the individual products. This information was obtained from knowledgeable experts and from the literature (Josephson and Peterson 1982). The fourth factor, the largest uncertainty in the calculation, is the fraction of production that will likely benefit from radiation treatment. The estimated values are engineering judgments from the authors. The final factor used in the calculations is the efficiency of the irradiation process. A set of

(a) $\quad F A O=$ Food and Agriculture Organization; IAEA = International Atomic Energy Agency; WHO = World Health Organization. 
recent designs of irradiators with three base efficiencies (Bloonster et al. 1985) has been prepared for agricultural products. The lowest efficiency design was used for whole pork carcasses with an efficiency of $9.5 \%$, an intermediate value of $29 \%$ was used for packaged beef, poultry, and fish, and the highest value of $48 \%$ was used for all other boxed products. The efficiency of the process is concerned with the fraction of the radiation adsorbed by the material, the fraction of time each day that the plant is irradiating material, and the number of days per year that the plant is processing various materials. The high values for source efficiency assumed for packed produce may significantly underestimate the need because of the seasonal nature of treatment needs of foods versus the annual average assumed.

With this information, Table 3.4 was prepared. As indicated in the table, the eventual need for gamma source inventory for agriculture is estimated to be $75 \mathrm{MCj}$ of ${ }^{60} \mathrm{Co}$. It can be noted that the most significant requirements are for the meat and spice markets. Most of the other products do not require 1 arge doses. In making this estimate, no effort has been made to adjust the capacity for seasonal production. This seems reasonable because the major use is for meats, which would have a relatively constant usage and availability year-round. Most other agriculture products would have definite seasons of need and Timited use out of season. It is expected that not all of the products identified in Table 3.4 wi1l be treated by radiation. However, it is also expected that a higher percentage of some of the products will be treated than is indicated in the table. Therefore, the overall estimate should be appropriate.

When the installed capacity of $75 \mathrm{MC} i$ of ${ }^{60} \mathrm{Co}$ will be needed is highly uncertain. With the projection of rapid initial growth rates of $60 \%$, decreasing to $5 \%$ in 1996, it was finally estimated that about 10 years would be required for the $75-\mathrm{MCi}\left({ }^{60} \mathrm{Co}\right)$ market to be established. High rates of early growth are expected because of the small $\left(-2 \mathrm{MCi}{ }^{60} \mathrm{Co}_{0}\right)$ current use rate.

Similar calculations have been based on various assumptions and have resulted in a range of values. Figure 3.1 shows a comparison of several recent studies on the potential growth of the irradiation industry. The 
TABLE 3.4. Gamma Use for Food Irradiation

\begin{tabular}{|c|c|c|c|c|}
\hline Product & $\begin{array}{c}\text { Current } \\
\text { Production, } \\
\text { Metric Tons/yr } \\
\end{array}$ & $\begin{array}{l}\text { Assumed } \\
\text { Dose, } \\
\text { krad } \\
\end{array}$ & $\begin{array}{l}\text { Potential } \\
\text { Fraction } \\
\text { Treated, \% } \\
\end{array}$ & $\begin{array}{l}{ }^{60} \mathrm{Co} \text { Inventory } \\
\text { Required. } \mathrm{MCi}\end{array}$ \\
\hline Beef & $10,714,400$ & 200 & 10 & 18.98 \\
\hline Pork & $6,719,200$ & 30 & 30 & 16.04 \\
\hline Poultry (cut up) & $2,974,189$ & 200 & 30 & 15.81 \\
\hline Spices & 275,000 & 1,000 & 60 & 8.63 \\
\hline Fish & $1,906,074$ & 100 & 30 & 5.07 \\
\hline Potatoes & $164,348,000$ & 10 & 5 & 4.30 \\
\hline Strawberries & 449,460 & 200 & 50 & 2.35 \\
\hline Oranges & $8,902,713$ & 25 & 20 & 2.33 \\
\hline Grapefruit & $2,338,554$ & 25 & 20 & 0.61 \\
\hline Apples & $3,792,262$ & 30 & 10 & 0.59 \\
\hline Other Citrus & $1,659,370$ & 25 & 20 & 0.43 \\
\hline Mushrooms & 234,784 & 30 & 50 & 0.18 \\
\hline Pears & 702,792 & 30 & 10 & 0.11 \\
\hline Onions & $1,982,164$ & 10 & 10 & 0.10 \\
\hline Nuts & 232,448 & 25 & 20 & 0.06 \\
\hline Avocados & 123,942 & 30 & 20 & 0.04 \\
\hline Papayas & 26,409 & 25 & 80 & 0.03 \\
\hline Cherries (sweet) & 153,452 & 30 & 10 & 0.02 \\
\hline Asparagus & 31,644 & 10 & 10 & $\frac{<0.01}{75.0}$ \\
\hline
\end{tabular}

basic differences between the studies are: 1) the types of products considered, 2) the fraction of the product that will be treated, 3) the type of treatments considered, and 4) the timing of acceptance of irradiation treatment. The Omega Research predictions are based on pork and poultry and peak because of their assumption that much of the treatment beyond 1990 will be performed by machine-generated irradiation rather than gamma source materials. The Kidder-Peabody results include the major increases in capacity for shelf-life extension of products, which was not included in this and other lower-usage studies (Gidwani 1986). If the irradiation market develops as projected by Kidder-Peabody, then much larger quantities of gamma source material will be needed than projected by this study, and development 


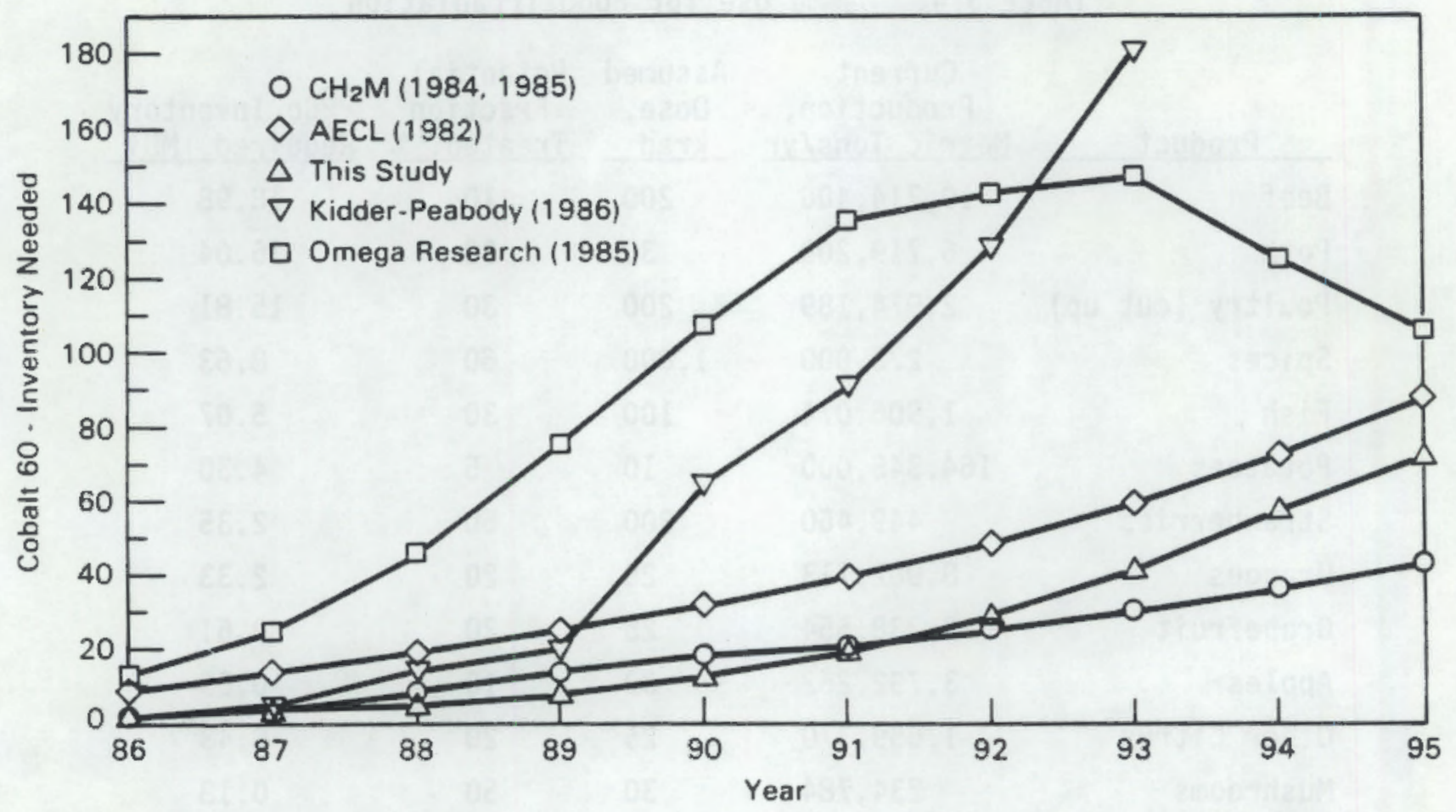

FIGURE 3.1. Comparison of Projected Gamma Needs for Food Irradiation

of machine irradiators will be needed as projected by Omega Research. The AECL results (Ouwerkerk 1982) are for all of the world, whereas the other studies are confined to the U.S. only. With this consideration, the AECL and $\mathrm{CH}_{2} \mathrm{M} \mathrm{Hill} \mathrm{results} \mathrm{are} \mathrm{quite} \mathrm{consistent} \mathrm{with} \mathrm{the} \mathrm{projection} \mathrm{of} \mathrm{this} \mathrm{study} \mathrm{in}$ the near term, but the results of this study and the AECL study are higher for years beyond the early 1990s.

\subsubsection{0ther Potential Uses}

Gamma radiation has many other uses, a significant one of which is cancer treatment. Currently, approximately $13 \mathrm{MCi}$ of cobalt and a limited amount of ${ }^{137} \mathrm{Cs}$ are used for cancer therapy in the United States. Linear accelerators are increasing in this use. Cobalt sources continue to be used, but less frequently. No growth in these markets was considered in this study. Cesium-137 is also used in blood irradiators to eliminate graftversus-host (GVH) causing lymphocytes in blood, thereby controlling GVH disease in immunosuppressed patients (CRA 1987). Other isotopes such as thulium-170 can also be used for blood irradiation (Hungate 1974). 
Irradiation can be used for polymerization and treatment of plastics. Typical products and applications include: wiring insulation, heat-shrinkable plastics, impregnated wood flooring and other porous materials, bonding of paper coatings, production of clear plastic wrapping for food, and setting of green rubber ("Food Irradiation Technology in the United States" 1982; DOE 1983; Kirk-0thmer 1980). Most of these uses are ongoing in the United States and worldwide. Machine-generated electron beam radiation is principally used to process many of these products, but when the density of the material or contained product is high, ganma radiation from ${ }^{60} \mathrm{Co}_{0}$ is preferred. For example, a low-maintenance flooring, highly resistant to abrasion and indentation, is produced by impregnating flooring sections with acrylic resins and then irradiating them with gamma radiation to polymerize the resin and produce parquet sections. These sections meet or exceed National Bureau of Standards requirements and are used in commercial floors and other floors where minimum maintenance is required. As a point of interest, this type of flooring is used in the lobby at DOE's office in Germantown, Maryland.

The treatment of sewage solids has been studied by Sandia for many years and shown to be effective (Sandia 1978).

A major fraction of current U.S. oil production is acquired by water injection into existing oil wells when they cease flowing by natural processes. Both fresh water and sea water are used; however, both contain organisms which, under the anaerobic conditions in the well, can produce hydrogen sulfide. This chemical can sour the whole oil field, causing safety and processing problems. One of several methods proposed for preventing the organisms from souring oil wells is to sterilize the water before it is pumped into the well. Irradiating the total volume of water pumped into the well does not appear to be feasible because of the quantities of isotope required, but experience has shown that large filters can be used, with a high degree of efficiency, to trap algae and other marine biota. Continuously irradiating the filter beds where these organisms are held up, concentrated, or trapped may be an effective option for destroying the biota. Process methods have not been studied in detail, and further evaluations are 
required although some proprietary work has been done by industry. The use of gamma source materials for such new applications has not been considered in our estimates of source material needs.

\subsection{DISPLACED PRODUCTS}

The expanded use of irradiation in food processing and other industrial areas should have little impact on alternative methods of treatment for two reasons: radiation treatment will largely supplement other methods rather than displace them, or it will fill needs not adequately handred now. Where displacement occurs (e.g. for disinfestation), regulatory and institutional barriers are driving the changes rather than the economics and technological factors.

\subsubsection{Food Processing and Agriculture}

Radiation is proposed as the alternative treatment for fumigating fruits and other farm products to replace EDB and ethylene oxide which have been Timited by EPA orders. Both chemicals have been found to be carcinogenic and have been identified in residual quantities in treated produce or in exposed farm workers. Thus, the displacement of fumigation by radiation may occur because regulatory barriers have been raised against one form of processing (chemical) and lowered for an alternative treatment (irradiation).

Long-term preservation of the food would still require refrigeration to minimize regrowth of the bacteria and to 1 imit action of enzymes that cause spoilage of the particular food product; however, the overall refrigeration energy requirements would be reduced at a net cost savings because of the radiation treatment. Treatment would serve as a supplement to other preservation methods and provide a conservation measure that is otherwise not available ("Food Irradiation Technology in the United States" 1982).

\subsubsection{Medica1 Products Applications}

Sterilization of medical products is a prime example of regulatory actions causing a displacement as well as an example of industry recognizing a beneficial use for radiation treatment that is superior to other a) ternatives. 
Most of the medical industry was sterilizing products with ethylene oxide gas because it was cheap, functional, and apparently safe. In 1977, the EPA released the results of toxicity tests that showed that ethylene oxide was mutagenic. Additional tests performed both by industry and regulatory agencies provided strong evidence that ethylene oxide was also a carcinogen. After the EPA required phasing out ethylene dibromide and ethylene oxide in 1977 and the Occupational Safety and Health Association (OSHA) reduced permissible occupational exposures, many large medical product manufacturers and companies began to evaluate alternative processes. Radiation emerged as the most viable solution. 



\subsection{PUBLIC ACCEPTANCE AND REGULATORY FACTORS}

Public acceptance of a new technology depends on public opinions, industry activities, regulatory climate, and political factors that enable a new technology to develop to meet a recognized need. Acceptance of a new technology does not require universal popularity or absence of public or political opposition.

\subsection{PUBLIC ACCEPTANCE}

The final test of the acceptance of irradiated food will be by consumers. Limited tests have been conducted and have been generally positive. Marketing surveys have been conducted by several groups and summarized by Brand (1986). These surveys indicate a general willingness to use irradiated food. In the different studies, $20 \%$ to $30 \%$ of those polled indicated a negative view and $23 \%$ to $77 \%$ indicated a positive view. The balance of people were undecided.

The typical process of public acceptance of a new technology involves several factors: 1) benefits, 2) risk of major disaster, 3) technology control or safeguards, and 4) assessment of the bases of support and opposition.

1. To win eventual acceptance, a technology must deliver genuine benefits to society. For example, tail fins on automobiles temporarily caught the pubiic fancy, but aerodynamics eventually prevailed based on performance benefits.

2. During the early period of technology introduction, it is important that there be no real or apparent disasters connected with the technology. An event such as the Hindenberg crash or a nuclear accident with significant loss of 1 ife can kill or greatly delay acceptance of the related technology.

3. People must have confidence in the new technology's control mechanisms. To a society familiar with horses, reliable brakes were necessary before the automobile was accepted.

4. Finally, the scope of those who benefit and those who bear the risk or impacts from the new technology is important. If benefits are widely experienced, as with microwave ovens, and risks minimized by effective technology controls, acceptance is rapid and widespread. If benefits are narrowly enjoyed, but risks and impacts are widely experienced, acceptance is in jeopardy. The Supersonic transport is 
an example. Only a few would benefit, but all public would be exposed to the potential loss of the ozone layer in the atmosphere.

The dynamic social process that causes the formation of public opinion about who gains and who loses is often shaped by special interest groups. Opposition to a new technology can be particularly effective if major value issues can be linked to the technology. For example, personal freedom: fluoridation of water faced determined opposition because it applied to everyone served by the water system and thwarted freedom of choice. By contrast, regulatory blockage of saccharin was reversed because freedom of choice is possible by the use of product labeling.

The following discussion of public acceptance addresses each of these factors and will be based almost entirely on food irradiation because other uses of irradiation are so little known to the public. One exception to this is sterilization of medical devices and disposable medical supplies. Public opposition to this use has been limited to individual facilities without national attention.

\subsubsection{Perceived Benefits}

Media accounts, testimony in hearings, and industry position statements stress three major benefits of food irradiation. These are:

- equal or improved effectiveness as compared to current methods of treating foods

- greater protection from health risks either from chemical treatment or from no current treatment

- access to foreign markets now closed because of concern for insect infestation.

These benefits seem to be accepted by most interested parties, but they are being challenged by some consumer groups (U.S. Department of Health and Human Services 1986, 1988).

\subsubsection{Risk of Disaster}

The nature of food irradiation technology limits the opportunity for major disaster. While there have been fears expressed about health effects of radiolytic products resulting from the irradiation process, the radiolytic 
products are in very low concentrations and are often produced during the cooking of food and do not represent a new or serious hazard.

Nor do transportation of irradiation sources or operation of irradiation facilities appear to pose much risk of dramatic consequences. The existing transportation record is excellent. However, as the size of shipments increases, opponents could conceive more disastrous scenarios. Experience with the 42 commercial irradiators currently licensed by the NRC shows only two serious exposures, both occupational.

Concern about the possibility of induced radioactivity has been laid to rest by careful analysis, including studies by the National Bureau of Standards and the National Academy of Sciences. However, public misconceptions and lack of information may continue to keep this issue in the public consciousness.

The Chernobyl power reactor accident has increased public concern with nuclear reactors and radiation. The impact on radiation processing activities is not known, but the accident will increase awareness of radiation in the environment.

\subsubsection{Technology Control}

In our society, anything associated with radiation is of concern to the public. Fears associated with nuclear technology are quite persistent, and there is evidence that perhaps $20 \%$ of the public is strongly negative about anything associated with nuclear technology. Somehow the use of radiation in medicine has largely escaped this public scrutiny, but it seems unlikely that food irradiation will be as easily accepted.

The FDA received over 5000 comments in response to proposed standards (21 CFR 179) of $100 \mathrm{krad}$ for sprout inhibition, shelf-life extension of fresh fruit and vegetables, and insect disinfestation and 3 Mrad for sterilization of spices. Over $90 \%$ of these comments were negative. Systematic analys is of the comments was completed and reported with the final regulation (U.S. Department of Health and Human Services 1986, 1988). The reported concerns included safety of radiolytic products, need for reliable long-term feeding studies, nutrition, growth of microorganisms or toxin production by micro- 
organisms not kilied by the process, retail labeling, enforcement of dose limits, training of operators, and the transport, storage, and disposal of nuclear materials.

While all of these issues address safety in one way or another, it is difficult to determine how important or persistent such public doubts will be. Analysis of the comments helped, but it is also important to evaluate the confidence and ease with which public concerns can be answered. The FDA expressed "reasonable certainty of no harm" (the finding required under their statutory authority) that the proposed standards will be safe. Though the FDA took a conservative stand on the safety of higher doses than those proposed (100 krad for fruit and vegetables and 3 Mrad for spices, dried onions, and garlic), it reported no negative data on health effects from food irradiation. It is also significant that the World Health Organization has set much higher dose standards that are being used in many parts of the world with no reported negative health effects.

The NRC position presented by Richard E. Cunningham at the July 26, 1984, FDA committee hearings was unequivocal. The experience with ${ }^{60} \mathrm{Co}$ irradiators had been good and "... the NRC is not conducting, nor do we presently foresee a need to conduct, safety-related research to enhance the regulatory base."

The very confidence with which the proponents of food irradiation deal with public concerns leads to the conclusion that eventually these concerns will be adequately addressed.

\subsubsection{8asis of Opposition}

Several groups have organized to oppose food irradiation (Webb 1987). The Coalition to Stop Food Irradiation is concerned about the use of the radioactive sources to treat the food. They say the use of such sources will increase risk of nuclear accidents to workers and to society in general. They also oppose use of a cesium source from the production of plutonium for weapons. The Environmental Policy lnstitute, a Washington D.C. based group, has expressed concern about radiolytic byproducts, vitamins, the safety of processors, the transportation of sources, and the use of food irradiation as 
an issue to justify the reprocessing of spent fuel (Zurer 1986). A spokesperson for Critical Mass, a coalition of opponents of nuclear weapons and nuclear power, has expressed concern that food irradiation may contribute to the legitimization of the weapons business and the spread of nuclear materials that could contaminate the environment. Such concerns are essentially ideological and cannot be responded to easily. Most organized consumer groups are vocally opposed or at least skeptical of food irradiation (Semling 1984).

In general, the food industry seems to be cautiously positive about food irradiation (Semling 1984; Packaging Digest 1986). The National Marine Fisheries Service sponsored marketing research in radiation treatment of fish and its subsequent acceptance by the public (Brand 1986). The report was generally positive, and other food processors are running product tests. Experience with acceptance of irradiated food at special food industry events is overwhelmingly positive but obviously is not a reflection of the attitude of the entire general public. There is serious concern from processors about negative reactions to their major brands. Early marketing will therefore likely involve new brands and slow introduction of the technology.

These indicators suggest two value issues associated in a negative way with food irradiation: the general association with nuclear technology and the concern for nuclear safety. Cesium-137 may present a special case if its use becomes more common and its origin as a nuclear waste byproduct is widely reported. Survey data show that the majority of the public feels nuclear waste is a very dangerous substance. Many feel there is no suitable way to dispose of it, and some think no suitable way will ever be found. In the face of these beliefs, the association of nuclear waste with food irradiation would clearly concern some members of the public. In contrast, cobalt use would not be expected to face the same opposition.

If irradiation technology expands, organized opposition that has or may develop may be countered by organized support from the medical and food industries. In addition to the economic factors associated with building and operating irradiation facilities (and disposing of the facilities they displace), attention should be given to what some call the "hassle factor" associated with any nuclear technology other than nuclear medicine. It consists 
of regulatory burdens, political liabilities, and negative media attention. The difficulties electric utilities have in gaining approvals for nuclear plants illustrate this factor. There is no firm basis for thinking this hassle factor will become an important element in the approach the food industry takes to food irradiation, but it deserves attention. Without industry enthusiasm, food irradiation will not flourish.

\subsection{REGULATORY FACTORS}

On the whole, regulatory treatment has been quite cautious in the U.S. The early definition of irradiation as a food additive rather than a process under the Food Additives Amendment of 1958 has impeded the application of this technology by subjecting it to regulatory standards which had been formulated for chemical additives. The FDA approval of gamma irradiation of canned bacon in 1963 was rescinded in 1968 on the grounds that the design of feeding experiments used to certify its safety was questionable. The past few years have brought greater regulatory movement (U.S. Department of Health and Human Services 1985, 1986, 1988, U.S. Department of Agriculture 1989), and attention by regulatory agencies to public concerns. There were many concerns expressed in response to requests for comments on 21 CFR 179, and they appear to have been thoroughly addressed in the final rule (U.S. Depart-

ment of Heaith and Human Services 1986, 1988). 


\subsection{ALTERNATIVE SOURCES OF GAMMA RADIATION}

There are four major alternatives for providing gamma radiation for applications discussed in Section 3. These include:

- ${ }^{137}$ Cs separated as a byproduct from spent reactor fuel

- ${ }^{60} \mathrm{Co}$ generated from neutron activation of ${ }^{59} \mathrm{Co}$ in a reactor

- spent nuclear fuel itself with appropriate neutron shielding

- machine-generated radiation.

A brief comparison of cobalt, cesium, and spent fuel is presented in Table 5.1. The two values for cesium reflect a pure ${ }^{137} \mathrm{Cs}$ and the ${ }^{137} \mathrm{Cs}$ which would be produced by separation from nuclear fuel. The two values for cobalt also reflect a "pure" product and a commercial product produced during typical irradiation cycles. The two spent fuel characteristics are based on total activity within the fuel from all isotopes and from just the ${ }^{137} \mathrm{Cs}$ and ${ }^{60} \mathrm{Co}$ which are present within the fuel. A comparison is often made between cobalt and cesium. The comparisons are based on the effective dose provided in an irradiator. The comparative value as a source is a ratio of the gamma/ decay times the energy/gamma, which gives cobalt a value of 4.44 times that of cesium. The efficiency of the capsule design usually favors cobalt and often makes the comparative value greater than five in favor of cobalt. For this study, comparisons of source strength are based on a factor of five, except for WESF capsules, where a value of seven is used. Cesium has the advantage of longer half-life; the importance of this is explained in Section 7.2 .

Additional details on the use and availability of each of the alternative gamma sources are given in the following sections.

\subsection{CESIUM SOURCES}

Fission-product cesium in spent fuel freshly discharged from the reactor consists of the stable isotope ${ }^{133} \mathrm{Cs}$ and the radioactive isotopes ${ }^{134} \mathrm{Cs}$, ${ }^{135} \mathrm{Cs},{ }^{136} \mathrm{Cs}$, and ${ }^{137} \mathrm{Cs}$. Small quantities of cesium are potentially recoverable from current and future high-level defense wastes at a presentiy 
TABLE 5.1. Comparison of Cobalt, Cesium, and Spent Fuel as Irradiation Sources

\begin{tabular}{|c|c|c|c|c|c|}
\hline Radioisotope & $\begin{array}{l}\text { Half-Life, } \\
\frac{y r}{2}\end{array}$ & $\begin{array}{c}\text { Specific } \\
\text { Activity, } \\
\text { Ci/g }\end{array}$ & $\begin{array}{c}\text { Energy } \\
\text { Per Gamma, } \\
\text { MeV } \\
\end{array}$ & $\begin{array}{l}\text { Ganmas } \\
\text { Per Decay }\end{array}$ & $\begin{array}{c}\text { Assumed Use } \\
\text { Efficiency, } \\
\% \text { \%a) }\end{array}$ \\
\hline${ }^{137} \mathrm{Cs}$ (pure) & 30 & 87 & 0.662 & 0.85 & 95 \\
\hline${ }^{137} \mathrm{Cs}$ & 30 & $15-20$ & 0.662 & 0.85 & $60(b)$ \\
\hline${ }^{60} \mathrm{Co}$ (pure) & 5.3 & 1141 & $1.33 \& 1.17$ & 2.0 & 95 \\
\hline $\begin{array}{l}{ }^{60} \mathrm{Co} \\
\text { (commercial) }\end{array}$ & 5.3 & $40-100$ & $1.33 \& 1.17$ & 2.0 & 95 \\
\hline Spent Fue $(\mathrm{c})$ & $3(e)$ & 0.4 & Various & Various & 60 \\
\hline Spent Fuel (d) & $27(\mathrm{e})$ & 0.08 & 0.70 & 0.92 & 60 \\
\hline
\end{tabular}

(a) $100 \%$ efficiency would mean that all the gamma energy in the source was emitted for use. Instead, some of the gamma is stopped by the walls of the source.

(b) Based on efficiency of WESF capsules produced at Hanford (Jackson 1976).

(c) Based on 5-year-old fuel. Data based on total activity.

(d) Based on 5-year-0ld fuel. Data based on a weighted composite of cesium and cobalt isotopes in spent fuel (e.g., specific activity = $S$ weight fraction of $i x$ specific activity of $i)$.

(e) Half-iife is a composite of several isotopes and is not constant with time.

projected cost that is significantly greater than the cesium value (as compared to ${ }^{60}(0)$. Substantial quantities are potentially recoverable from commercial spent fuel (see Section 7 for a discussion of costs). The quality of the cesium will depend primarily on the time since the fuel was discharged because isotope concentrations decrease with time through decay. Because of their much shorter half-Tives, ${ }^{134} \mathrm{Cs}$ and ${ }^{136} \mathrm{Cs}$, though present at high activity levels initially, decay at much faster rates. The activity ratio of the ${ }^{134} \mathrm{Cs}$ to ${ }^{137} \mathrm{Cs}$ in the cesium decreases by a factor of about two every 2 years. The activity ratio of the ${ }^{136} \mathrm{Cs}$ to ${ }^{137} \mathrm{Cs}$ decreases by a factor of two about every 13 days. Cesium-135, which emits a low-energy beta, has a half-life of 2.3 million years. The ${ }^{135} \mathrm{Cs}$ activity has no significant effect on potential uses of ${ }^{137} \mathrm{Cs}$, but the mass of the ${ }^{135} \mathrm{Cs}$ does dilute the ${ }^{137} \mathrm{Cs}$ recovered. The distribution of cesium isotopes in the current spent fuel 
inventory is shown in Table 5.2. Depending on the effectiveness of the recovery and purification schemes, the cesium could also contain some chemical impurities.

The estimated inventories of ${ }^{137} \mathrm{Cs}$ available from various sources are presented in Table 5.3. Commercial spent fuel is the predominant potential source.

\section{Hanford}

At Hanford, cesium has been recovered from stored defense high-level wastes (HLW) to reduce heat loading in waste storage tanks. The recovered cesium was purified, converted to cesium chloride, and doubly encapsulated in capsules of about 2-5/8 in. diameter and 20-3/4 in. long. The encapsulated cesium chloride has been stored in water basins at the Waste Encapsulation and Storage Facility (WESF) (Jackson 1976). From 1985 through 1987 over half of the inventory was shipped to facilities for demonstration and commercial irradiation under a DOE source leasing program. A portion of the remaining material has been used in DOE programs. The existing Hanford capsules are presently the only major U.S. source of ${ }^{137} \mathrm{Cs}$.

About $80 \%$ of the cesium in the high-level waste tanks has been recovered and converted to cesium chloride. The remaining $20 \%$ is contained in insoluble sludge layers in waste tanks, salt cake, and double-shell tank slurry (residual liquor), and is considered unavailable for recovery at the present time. Thus, it has not been included in the total listed in Table 5.3. It is estimated that up to about $95 \%$ of the cesium could be recovered from future PUREX wastes.

The ratio of ${ }^{137}$ Cs to total cesium is about 0.44 for newly discharged spent fuel. However, because of aging of stored waste and ${ }^{137} \mathrm{Cs}$ decay, the ratio has diminished to about 0.30 to 0.40 in cesium chloride. The chemical purity of the cesium chloride also varies, depending on several factors. The chlorides of sodium, potassium, rubidium, calcium and barium are the principal impurities. Other impurities result from corrosion of the processing equipment. Overall, impurities in the cesium chloride are less than $8 \%$. 
TABLE 5.2. Cesium Inventory in One Metric Ton of Commercial Spent Fue] With 32,700 Megawatt-Day Burnup 5 Years After Discharge (Slate 1981)

\begin{tabular}{|c|c|c|c|}
\hline Isotope & Half-Life & $q$ & $\mathrm{Ci}$ \\
\hline${ }^{133} \mathrm{cs}$ & Stable & 1,113 & -- \\
\hline${ }^{134} \mathrm{Cs}$ & $2 \mathrm{yr}$ & 22 & 2,800 \\
\hline${ }^{135} C_{S}$ & $2 \times 10^{6} \mathrm{yr}$ & 287 & 0.33 \\
\hline 137 Cs & $30 \mathrm{yr}$ & 1,050 & 9,100 \\
\hline ROUNDED TOTALS & & 2,470 & 11,900 \\
\hline
\end{tabular}

IABLE 5.3. Estimated Inventories of Cesium-137 from Various Sources

Source

Hanford

Encapsulated cesium chloride through 1/87

Future reprocessing through 1990

(Operation of N-Reactor through 1986)

Savannah River Plant

Current wastes through $1 / 87$

Future wastes through $1 / 2000$

West Valley

Current wastes

Commercial Spent Fuel

Through 1986

Through 1990

Through 2000

Through 2020
110

20

1,400

2,100

4,100

75

24

9,800

\section{Savannah River Plant}

The HLW currently stored at the Savannah River Plant (SRP) contains about $100 \mathrm{MC}$ i of ${ }^{137} \mathrm{Cs}$. Eighty percent of ${ }^{137} \mathrm{Cs}$ in the waste is contained in 11 storage tanks. The remaining $20 \%$ is not considered recoverable at this time, and is not inciuded in the inventory. The ${ }^{137} \mathrm{Cs}$ isotope content of the cesium in the tanks is estimated to range from 20 to $40 \%$. 
Future generation of ${ }^{137}{ }_{C S}$ at SRP is estimated to decrease significantly in the next decade, with future production through the year 2000 equalling about $20 \mathrm{MCi}$.

\section{West Valley, New York}

Approximately $7 \mathrm{MCi}$ of ${ }^{137} \mathrm{Cs}$ that is in the supernatant phase of the $\mathrm{HLW}$ stored at West Valley, New York, is currently planned to be vitrified along with other West Valley HLW.

\subsubsection{Recovery of Cesium and Other Radioisotopes from Spent Fuel by Thermal Qutgassing}

Availability of ${ }^{137} \mathrm{Cs}$ and other radioisotopes from commercial spent fuel will depend on the degree (if any) of spent fuel treatment for waste management or other purposes. One potential spent fuel treatment is thermal outgassing.

Thermal outgassing consists of heating the irradiated fuel with its associated cladding to a temperature of $1500^{\circ} \mathrm{C}$ in a controlled atmosphere sweep gas (helium or helium plus $6 \%$ hydrogen) for about $6 \mathrm{~h}$. This technique has been shown to be effective in the removal of various volatile and "semivolatile" fission products from commercial irradiated $\mathrm{UO}_{2}$ fuel (Bray et al. 1983). A summary flowsheet is shown in Figure 5.1. Table 5.4 shows the projected composition of different process streams.

The PNL studies (Bray et al. 1983) assumed fuel would be sheared into pieces prior to the thermal outgassing treatment. However, some evidence exists (Bray et al. 1983) that indicates exposure to the correct sweep gas composition at elevated temperature results in a brittle cladding that is easily fractured. Thus, mechanical fracturing of the cladding may be a viable alternative to fuel shearing.

Complete release of krypton and xenon from the fuel, and tritium from both the fuel and cladding, has been demonstrated (Bray et ai. 1983). About $86 \%$ of the ${ }^{129} \mathrm{I}$ and $95 \%$ of the cesium were released at $1500^{\circ} \mathrm{C}$ in a sweep gas of pure helium. A sweep gas composition of helium plus $6 \%$ hydrogen improves the kinetics of tritium release but hinders krypton and xenon release. Cesium remains in the fue 7 when the helium plus $6 \%$ hydrogen sweep gas is 


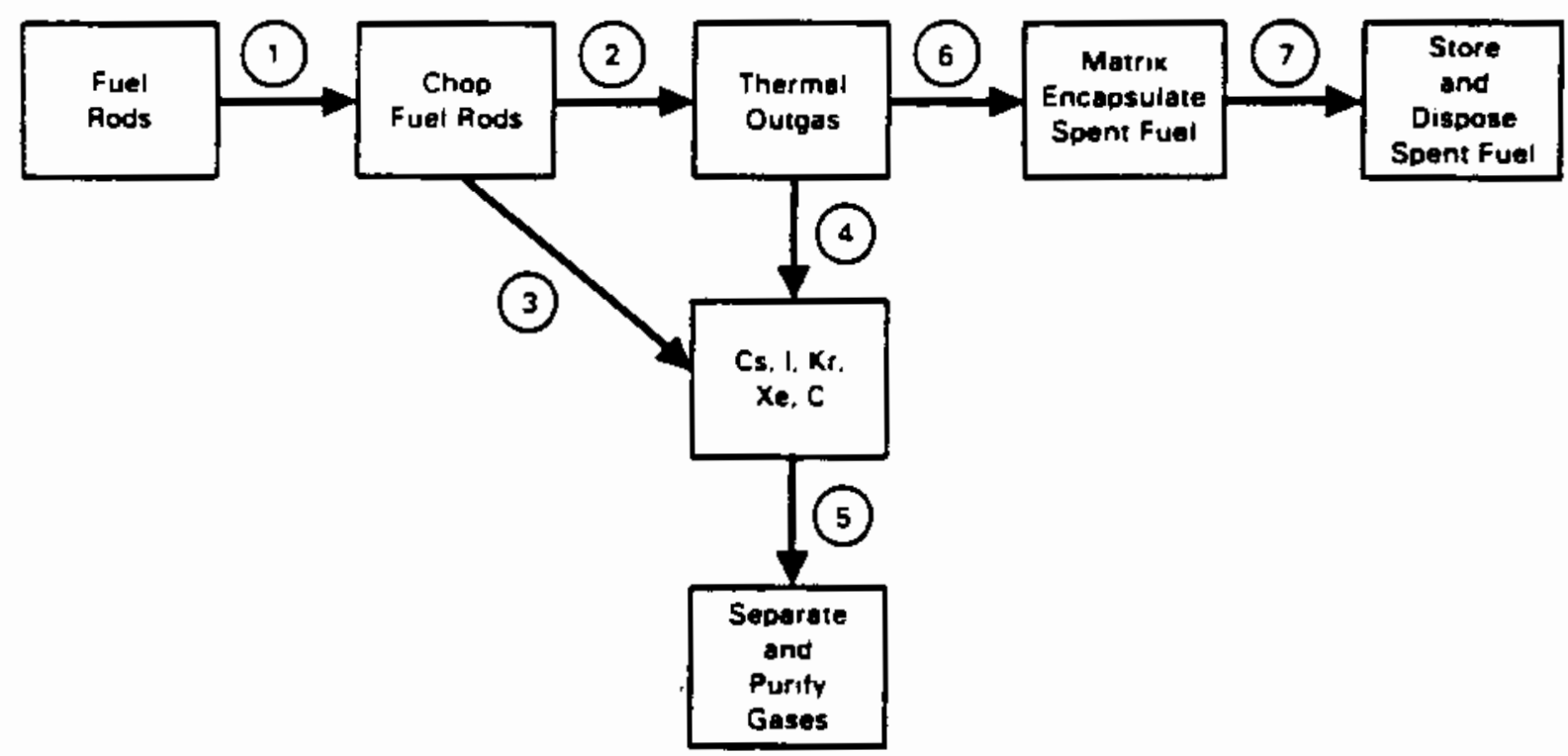

EIGURE 5.1. Flowsheet for Thermal Outgassing

used. Adjustment of the sweep gas composition can be used to perform an initial separation of the fission products tritium, krypton, xenon, and cesium.

The thermal outgassing flowsheet shown indicates the major steps in this process. These steps include:

- fuel rod shearing or chopping

- fue] rod heat treatment or thermal outgassing

- semivolatile removal (i.e., cesium etc.)

- iodine adsorption

- conversion of tritium to tritiated water

- tritiated water adsorption

- krypton and xenon adsorption.

In the process, the sweep gas is decontaminated and recycled. 
TABLE 5.4. Flowsheet for Thermal Outgassing for 10-Year-01d Spent Fue1 with 30,000 MWD/MTU Burnup (values/MT)

\begin{tabular}{|c|c|c|c|c|c|c|c|c|}
\hline \multirow[b]{2}{*}{ Element } & \multicolumn{2}{|c|}{ Stream \#1 } & \multicolumn{3}{|c|}{ Stream \#2 } & \multicolumn{3}{|c|}{ Stream $\# 3$} \\
\hline & Grams & Curies & Fraction & Grams & Curies & Fraction & Grams & Curies \\
\hline U & 960,000 & 6.3 & 1 & 960,000 & 6.3 & 0 & 0 & 0 \\
\hline $\mathrm{Pu}$ & 11,000 & 3,000 & 1 & 11,000 & 3,000 & 0 & 0 & 0 \\
\hline $\mathrm{Np}$ & 550 & 18 & 1 & 550 & 18 & 0 & 0 & 0 \\
\hline$C$ & 0.13 & 0.6 & 1 & 0.13 & 0.6 & 0 & 0 & 0 \\
\hline T & 0.016 & 160 & 1 & 0.016 & 160 & 0 & 0 & 0 \\
\hline I & 250 & 0.034 & 1 & 250 & 0.034 & 0 & 0 & 0 \\
\hline $\mathrm{Kr}$ & 300 & 4,400 & 0.9 & 270 & 3,960 & 0.1 & 30 & 440 \\
\hline$X e$ & 4,600 & & 0.9 & 4,140 & 0 & 0.1 & 460 & 0 \\
\hline Cs & 2,400 & 83,000 & 1 & 2,400 & 83,000 & 0 & 0 & 0 \\
\hline Sr & 690 & 53,000 & 1 & 690 & 53,000 & 0 & 0 & 0 \\
\hline Ru & 2,000 & 380 & 1 & 2,000 & 380 & 0 & 0 & 0 \\
\hline Pd & 1,200 & 0.093 & 1 & 1,200 & 0.093 & 0 & 0 & 0 \\
\hline Rh & 380 & 380 & 1 & 380 & 380 & 0 & 0 & 0 \\
\hline
\end{tabular}

Stream \#4 stream \#5

\begin{tabular}{|c|c|c|c|c|c|c|c|c|c|}
\hline & & & & & & & & & \\
\hline Element & \multicolumn{2}{|r|}{ Grams } & Curies & Fraction & Grams & Curies & Fraction & Grams & Curies \\
\hline $\mathrm{U}$ & 0 & 0 & 0 & 0 & 0 & 0 & 1 & 960,000 & 6.3 \\
\hline $\mathrm{Pu}$ & 0 & 0 & 0 & 0 & 0 & 0 & 1 & 11,000 & 3,000 \\
\hline Np & 0 & 0 & 0 & 0 & 0 & 0 & 1 & 550 & 18 \\
\hline C & 0.8 & 0.104 & 0.48 & 0.8 & 0.104 & 0.48 & 0.2 & 0.026 & 0.12 \\
\hline $\mathrm{T}$ & 0.8 & 0.0128 & 128 & 0.8 & 0.0128 & 128 & 0.2 & 0.0032 & \\
\hline 1 & 0.86 & 215 & 0.02924 & 0.86 & 215 & 0.02924 & 0.14 & 35 & 0.00476 \\
\hline $\mathrm{Kr}$ & 0.9 & 270 & 3,960 & 1 & 300 & 4,400 & 0 & 0 & \\
\hline $\mathrm{Xe}$ & 0.9 & 4,140 & 0 & 1 & 4,600 & 0 & 0 & 0 & \\
\hline Cs & 0.95 & 2,280 & 78,850 & 0.95 & 2,280 & 78,850 & 0.05 & 120 & 4,150 \\
\hline$S r$ & 0 & 0 & 0 & 0 & 0 & 0 & 1 & 690 & 53,000 \\
\hline Ru & 0 & 0 & 0 & 0 & 0 & 0 & 1 & 2,000 & 380 \\
\hline Pd & 0 & 0 & 0 & 0 & 0 & 0 & 1 & 1,200 & 0.093 \\
\hline Rh & 0 & 0 & 0 & 0 & 0 & 0 & 1 & 380 & 380 \\
\hline
\end{tabular}


Equipment requirements are reasonable, and all needed equipment consists of off-the-shelf items, including the $1500^{\circ} \mathrm{C}$ furnace. The thermal outgassing process has been demonstrated in hot-cell tests (Bray et al. 1983), and a conceptual design and cost estimate were prepared (01guin, Benedict, and Wilbourn 1982). The thermal outgassing process was determined to be a technically feasible process for the removal of volatile and semivolatile fission product elements from spent conmercial fuel.

\subsubsection{Recovery of Cesium and Other Radioisotopes from Spent Fuel by Chemical Reprocessing}

Recovery of selected fission products from commercial spent fuel by chemical processing is closely related to existing chemical processes for the recovery of uranium and plutonium from irradiated nuclear fuel, and the removal of selected fission products from various existing high-level wastes. The chemical processing flowsheet shown in Figure 5.2 indicates the major features of a proposed recovery process. Table $\mathbf{5 . 5}$ shows projected composition of different process streams.

During the process, the irradiated fuel is chopped into suitable lengths and fed to a dissolver where the oxide fuel is dissolved in nitric acid. The cladding and other fuel hardware are separated after dissolution of the oxide fuel is complete and these materials are disposed of as solid waste. The dissolver is normally sparged with air during the dissolution process, resulting in a dissolver offgas consisting of air, oxides of nitrogen, all the krypton, xenon, and carbon contained in the fuel, and portions of the iodine.

Tritium is not released to the dissolver offgas but remains as tritiated water in the aqueous dissolver solution. The total quantity of tritium is probably not sufficient to justify its recovery from this aqueous phase, but recovery methods exist which have been demonstrated.

Recovery of krypton and xenon from the dissoiver offgas has undergone numerous studies. A typical recovery process for krypton and xenon consists of removal of iodine from the offgas using silver-loaded adsorbents, $\mathrm{NO}_{\mathrm{x}}$ and $\mathrm{CO}_{2}$ removal, conversion of oxygen in the offgas to water by catalytic recombination with hydrogen, and removal of water. Final recovery of krypton 


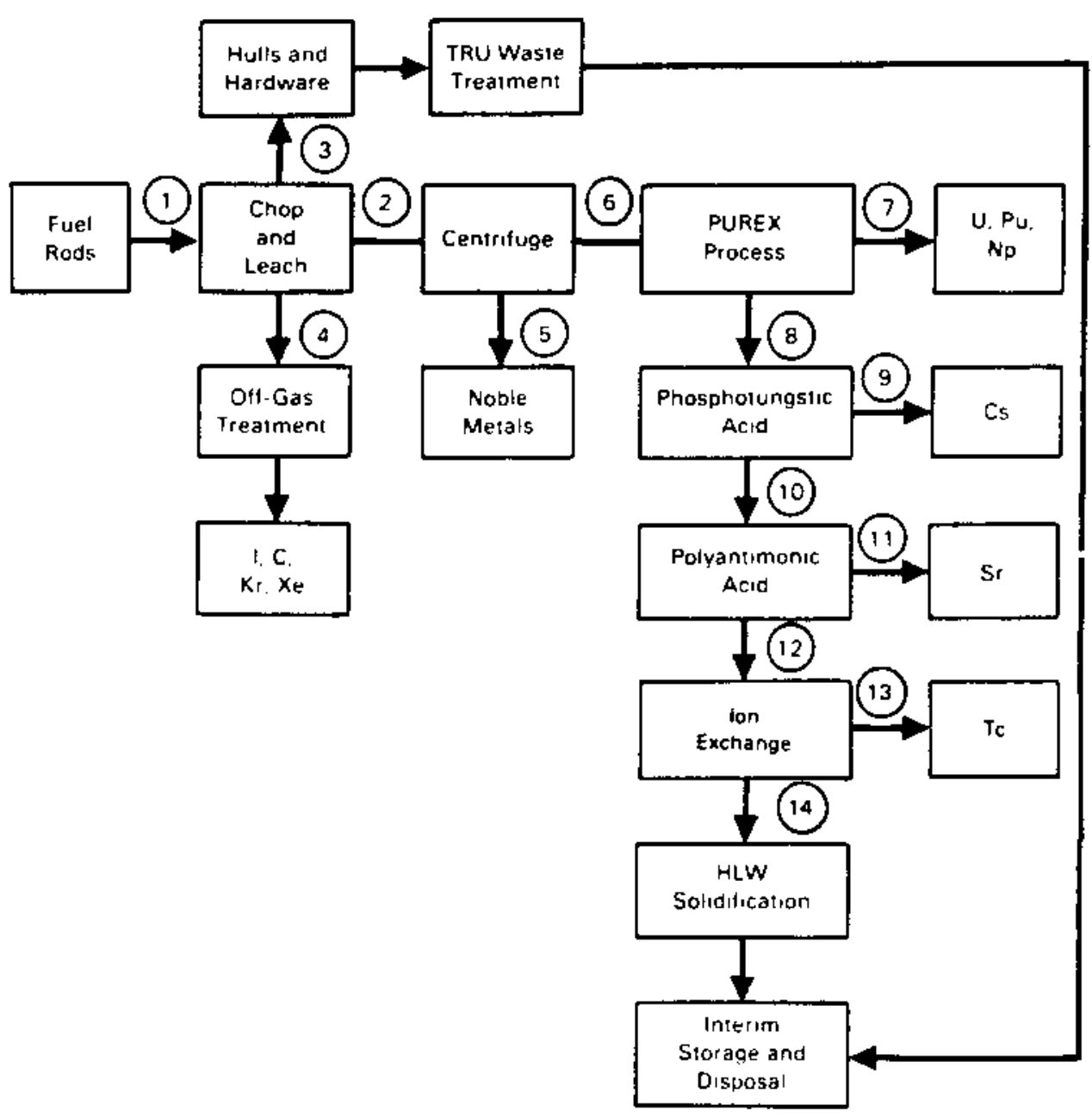

\section{FIGURE 5.2. Flowsheet for Chemical Processing}

and xenon from the remaining offgas (mainly nitrogen) is by cryogenic distillation. If the dissolver is sparged with pure oxygen rather than air, the nitrogen content in the offgas would be nearly eliminated.

The aqueous dissolver solution is normally centrifuged to remove cladding fines and undissolved fuel solids. About half of the fission product noble metals will be found in the undissolved solids and could be grossly separated from the hulls by particle size.

The clarified aqueous dissolver solution is then subjected to the PUREX process for recovery of the actinides, primarily uranium, plutonium, and neptunium. The remaining acidic solution contains the remainder of the fission products, including both cesium and strontium. 
TABLE 5.5. Flowsheet for Chemical Processing of 10-Year-01d Spent Fuel with 30,000 MWD/MTU Burnup

\begin{tabular}{|c|c|c|c|c|c|c|c|c|}
\hline \multirow[b]{2}{*}{ Elesuent } & \multicolumn{2}{|c|}{ streem } & \multicolumn{3}{|c|}{ Stres:in } & \multicolumn{3}{|c|}{ stregn $: 3$} \\
\hline & Grens & auriess & Erection & Grens & Curies & Fraction & Grens & Quries \\
\hline $\mathbf{U}$ & $\$ 60, \infty 00$ & 6.3 & 1 & $\$ 60,000$ & 6.3 & 0.005 & 4,800 & 0.0345 \\
\hline Pu & 11,000 & 3,000 & 1 & 11,000 & 3,000 & 0.005 & 550 & 15 \\
\hline Np & 550 & 18 & 1 & 550 & 18 & 0.005 & 2.75 & 0.09 \\
\hline C & 0.13 & 0.6 & 0 & 0 & 0 & 0 & 0 & 0 \\
\hline$T$ & 0.016 & 157 & 1 & 0.016 & 157 & 0 & 0 & 0 \\
\hline 1 & 246 & 0.034 & 0 & 0 & 0 & 0 & 0 & 0 \\
\hline $\mathrm{Kr}$ & 300 & 4,400 & 0 & 0 & 0 & 0 & 0 & 0 \\
\hline$x e$ & 4,600 & 0 & 0 & 0 & 0 & 0 & 0 & 0 \\
\hline Cs & 2,400 & 83,000 & 1 & 2,400 & 83,000 & 0 & 0 & 0 \\
\hline $\mathbf{S r}$ & 690 & 53,000 & 1 & 690 & 5,000 & 0 & 0 & 0 \\
\hline Ru & 2,000 & 376 & 1 & 2,000 & 376 & 0 & 0 & 0 \\
\hline Pd & 1,200 & 0.093 & 1 & 1,200 & 0.093 & 0 & 0 & 0 \\
\hline Rh & 380 & 376 & 1 & 380 & 376 & 0 & 0 & 0 \\
\hline TC & 760 & 13 & 1 & 760 & 13 & 0 & 0 & 0 \\
\hline $\begin{array}{l}\text { HULLS \& } \\
\text { HARDYARE }\end{array}$ & 300,000 & 11,000 & 1 & 300,000 & 11,000 & 1 & 300,000 & 11,000 \\
\hline
\end{tabular}

\begin{tabular}{|c|c|c|c|c|c|c|c|c|c|}
\hline \multirow[b]{2}{*}{ El ement } & \multicolumn{3}{|c|}{ Strean } & \multicolumn{3}{|c|}{ Strean 4} & \multicolumn{3}{|c|}{ Streen } \\
\hline & Eraction & Grens & curies & Frection & Grams & Quries & Fraction & Grems & Quries \\
\hline $\mathbf{u}$ & 0 & 0 & 0 & 0 & 0 & 0 & 0.995 & 955,200 & 6.26 \\
\hline Pu & 0 & 0 & 0 & 0 & 0 & 0 & 0.995 & 10,945 & 3,000 \\
\hline $\mathrm{Hp}$ & 0 & 0 & 0 & 0 & 0 & 0 & 0.995 & 547.25 & 97 \\
\hline C & 1 & 0.13 & 0.6 & 0 & 0 & 0 & 0 & 0 & \\
\hline $\mathbf{T}$ & 0 & 0 & 0 & 0 & 0 & 0 & 1 & 0.016 & \\
\hline 1 & 2 & 246 & 0.034 & 0 & 0 & 0 & 0 & 0 & \\
\hline $\mathbf{K r}$ & 1 & 300 & 4,400 & 0 & 0 & 0 & 0 & 0 & \\
\hline Xe & 1 & 4,600 & 0 & 0 & 0 & 0 & 0 & 0 & \\
\hline Cs & 0 & 0 & 0 & 0 & 0 & 0 & 1 & 2,400 & 830 \\
\hline $\mathrm{Sr}$ & 0 & 0 & 0 & 0 & 0 & 0 & 1 & 690 & 530 \\
\hline Ru & 0 & 0 & 0 & 0.5 & 1,000 & 188 & 0.5 & 1,000 & 1 \\
\hline Pd & 0 & 0 & 0 & 0.5 & 600 & 0.0465 & 0.5 & 600 & 0.04 \\
\hline Rh & 0 & 0 & 0 & 0.5 & 190 & 188 & 0.5 & 190 & 1 \\
\hline Tc & 0 & 0 & 0 & 0 & 0 & 0 & 1 & 760 & 13 \\
\hline $\begin{array}{l}\text { HULLS \& } \\
\text { HARDWARE }\end{array}$ & 0 & 0 & 0 & 0 & 0 & 0 & 0 & 0 & \\
\hline
\end{tabular}


TABLE 5.5. (contd)

\begin{tabular}{|c|c|c|c|c|c|c|c|c|c|}
\hline \multirow[b]{2}{*}{ Element } & \multicolumn{3}{|c|}{ Streen 77} & \multicolumn{3}{|c|}{ Strean 18} & \multicolumn{3}{|c|}{ strees } \\
\hline & Fraction & Grous & Curies & Frection & Grens & curies & Frection & frens & Quries \\
\hline$u$ & 0.99 & 950,400 & 6.237 & 0.005 & 4,800 & 0.0315 & 0 & 0 & 0 \\
\hline Pu & 0.99 & 10,890 & 3,000 & 0.005 & 55 & 15 & 0 & 0 & 0 \\
\hline Np & 0.99 & 544.5 & 17.82 & 0.005 & 2.75 & 0.09 & 0 & 0 & 0 \\
\hline c & 0 & 0 & 0 & 0 & 0 & 0 & 0 & 0 & 0 \\
\hline $\mathrm{T}$ & o & 0 & 0 & 1 & 0.016 & 157 & 0 & 0 & 0 \\
\hline 1 & 0 & 0 & 0 & o & 0 & o & 0 & 0 & o \\
\hline $\mathrm{Kr}$ & o & 0 & 0 & 0 & 0 & 0 & 0 & 0 & 0 \\
\hline$x e$ & 0 & 0 & 0 & 0 & 0 & 0 & 0 & 0 & 0 \\
\hline Cs & 0 & 0 & 0 & 1 & 2,400 & 83,000 & 0.9 & 2,160 & 74,700 \\
\hline $5 r$ & 0 & 0 & 0 & 1 & 690 & 53,000 & 0 & 0 & 0 \\
\hline Ru & 0 & 0 & 0 & 0.5 & 1,000 & 188 & 0 & 0 & 0 \\
\hline Pd & 0 & 0 & 0 & 0.5 & 600 & 0.0465 & 0 & 0 & 0 \\
\hline Rh & 0 & 0 & 0 & 0.5 & 190 & 188 & 0 & 0 & 0 \\
\hline Tc & 0 & 0 & 0 & 1 & 760 & 13 & 0 & 0 & 0 \\
\hline $\begin{array}{l}\text { HULLS \& } \\
\text { HARD WARE }\end{array}$ & 0 & 0 & 0 & 0 & 0 & 0 & 0 & 0 & 0 \\
\hline
\end{tabular}

\begin{tabular}{|c|c|c|c|c|c|c|c|c|c|}
\hline \multirow[b]{2}{*}{ Element } & \multicolumn{3}{|c|}{ streen $\# 10$} & \multicolumn{3}{|c|}{ Streen 141} & \multicolumn{3}{|c|}{ stresep 12} \\
\hline & Fraction & Grens & Curies & Frection & fresis & Curies & Frection & Grens & Curies \\
\hline $\mathbf{U}$ & 0.005 & 4,800 & 0.0315 & 0 & 0 & 0 & 0.005 & 4,800 & 0.0315 \\
\hline Pu & 0.005 & 55 & 15 & 0 & 0 & 0 & 0.005 & 55 & 15 \\
\hline Np & 0.005 & 2.75 & 0.09 & 0 & 0 & 0 & 0.005 & 2375 & 0.09 \\
\hline $\mathrm{c}$ & 0 & 0 & 0 & 0 & 0 & 0 & 0 & 0 & 0 \\
\hline$T$ & 1 & 0.016 & 157 & 0 & 0 & 0 & 1 & 0.016 & 157 \\
\hline I & 0 & 0 & D & 0 & 0 & 0 & 0 & 0 & 0 \\
\hline $\mathrm{Kr}$ & 0 & 0 & 0 & 0 & 0 & 0 & 0 & 0 & 0 \\
\hline $\mathrm{xe}$ & 0 & 0 & 0 & 0 & 0 & 0 & 0 & 0 & 0 \\
\hline Cs & 0.1 & 240 & 8,300 & 0 & 0 & 0 & 0.4 & 240 & 8,300 \\
\hline $\mathbf{S} \mathbf{r}$ & 1 & 690 & 53,000 & 0.9 & 621 & 47,700 & 0.1 & 69 & 5,300 \\
\hline Ru & 0.5 & 1,000 & 188 & 0 & 0 & 0 & 0,5 & 1,000 & 188 \\
\hline Pd & 0.5 & 600 & 0.0465 & 0 & 0 & 0 & 0.5 & 600 & 0.0465 \\
\hline Rh & 0.5 & 190 & 188 & 0 & 0 & 0 & 0.5 & 190 & 188 \\
\hline Tc & 1 & 760 & 13 & 0 & 0 & 0 & 1 & 760 & 13 \\
\hline $\begin{array}{l}\text { HULLS \& } \\
\text { HARDUARE }\end{array}$ & 0 & 0 & 0 & 0 & 0 & 0 & 0 & 0 & 0 \\
\hline
\end{tabular}


TABLE 5.5. contd

\begin{tabular}{|c|c|c|c|c|c|c|}
\hline \multirow[b]{2}{*}{ Elentent } & \multicolumn{3}{|c|}{ stre:m \#13 } & \multicolumn{3}{|c|}{ Strecm_:14 } \\
\hline & Eroction & Grews & Curies & Fraction & frr:as & Curies \\
\hline $\mathbf{U}$ & 0 & 0 & 0 & 0.005 & 4,800 & 0.0315 \\
\hline Pu & 0 & 0 & 0 & 0.005 & 55 & 600 \\
\hline N & 0 & 0 & 0 & 0.005 & 2.75 & 0.09 \\
\hline$c$ & 0 & 0 & 0 & 0 & 0 & 0 \\
\hline $\mathbf{T}$ & D & 0 & 0 & o & 0 & 0 \\
\hline $\mathbf{I}$ & 0 & 0 & 0 & 0 & 0 & 0 \\
\hline $\mathrm{Kr}$ & 0 & 0 & 0 & 0 & 0 & 0 \\
\hline$x e$ & 0 & 0 & 0 & 0 & 0 & 0 \\
\hline Cs & 0 & 0 & 0 & 0.1 & 240 & 8,300 \\
\hline Sr & 0 & 0 & 0 & 0.1 & 69 & 5,300 \\
\hline Ru & 0 & o & 0 & 0.5 & 1,000 & 188 \\
\hline Pd & 0 & 0 & 0 & 0.5 & 600 & 0.0465 \\
\hline $\mathbf{R h}$ & 0 & 0 & 0 & 0.5 & 190 & 188 \\
\hline Tc & 0.99 & 732.4 & 12.87 & 0.01 & 7.6 & 0.13 \\
\hline $\begin{array}{l}\text { HULLS \& } \\
\text { HARDUARE }\end{array}$ & 0 & 0 & 0 & 0 & 0 & o \\
\hline
\end{tabular}

Cesium can be recovered by precipitation from solution with phosphotungstic acid (PTA). Recent laboratory studies on West Valley wastes have obtained cesium decontamination factors ranging from 84 to 132 for hydrogen ion concentrations of 0.3 to $1.5 \mathrm{M}$, respectively (Bray 1984). Recovery of cesium from the original acidic fission product stream is expected to be at least as effective.

The acidic supernate resulting from cesium recovery using PTA contains the strontium and remaining fission products. Strontium can be precipitated by addition of polyantimonic acid to the acidic supernate. The solution is then $\mathrm{pH}$ adjusted, and $\mathrm{Tc}$ is removed by ion exchange. The remaining aqueous solution is then used as the feed stream to a high-level waste solidification process such as a liquid-fed ceramic melter.

Chemical processing for recovery of krypton, xenon, noble metals, cesium, and strontium utilizes demonstrated recovery processes and is therefore expected to be straightforward. 


\subsection{COBALT SOURCES}

Cobalt-60 makes a good irradiation source material because it has desirable physical properties (metal, ductile, strong, durable), can be generated by activation of ${ }^{59} \mathrm{Co}$, has high specific activity, and has a relatively long half-life.

The U.S. Atomic Energy Commission, in developing its Atoms for Peace program and its isotope development program, used its facilities at Hanford and Savannah River for the production of ${ }^{60} \mathrm{Co}$. These facilities produced megacurie quantities of ${ }^{60} \mathrm{Co}_{0}$ in the late 1960s. The current U.S. production is 7 imited to about $1 \mathrm{MCi} / \mathrm{yr}$, which is produced in the Advanced Test Reactor near Idaho Falls, Idaho.

General Electric Nuclear Energy Division in Pleasanton, California, used the General Electric Test Reactor to produce ${ }^{60} \mathrm{Co}$ until that reactor was shut down in the Tate 1970s. Neutron Products, in conjunction with the Big Rock Point reactor, began ${ }^{60} \mathrm{Co}$ production in 1966 that continued for 17 years.

Currentiy the principal source of supply is Nordion International, Inc. (formally Atomic Energy of Canada, Ltd.). They market cobalt produced in Canadian CANDU reactors when natural ${ }^{59} \mathrm{Co}$ is used as a secondary reactor control material producing ${ }^{60} \mathrm{Co}$ during power reactor operations. Only about 1 year of irradiation is required to produce the desired levels of ${ }^{60} \mathrm{Co}$ activity in the ${ }^{59} \mathrm{Co}$ in the heavy water moderated reactors. Activities of about $100 \mathrm{Ci} / \mathrm{g}$ are commonly produced, but higher levels can be produced with appropriate irradiation conditions. The current Canadian production capability is about $28 \mathrm{MCi} / \mathrm{yr}$, less than half of which comes to the United States. They appear to have a strong desire to maintain their status as the major world supplier, and are increasing their production capacity with the potential to produce $100 \mathrm{MCi} / \mathrm{yr}$ by 1995 (Fraser 1985), but their ability to meet that goal is not established. They are currently supplying ${ }^{60} \mathrm{Co}$ at a cost of about $\$ 1.36 / \mathrm{Ci}$ for a $0.5 \mathrm{MCi}$ order with a 15-year source warranty, and prices are expected to continue following the Canadian inflation rate which has recently been 3 to $5 \%$ per year. It was reported that the French and Soviets are also potential suppliers, but details of their production capacities are not available. 
There are several potential sources of ${ }^{60} \mathrm{Co}$ production within the United States. The potential production of ${ }^{60} \mathrm{Co}_{0}$ in the Fast Flux Test Facility (FFTF), an experimental reactor at Hanford, was evaluated. It was determined that about $3 \mathrm{MCi} / \mathrm{yr}$ could be produced; however, routine production would require significant modifications in facilities and reactor operations. A study by Toffer (1987) of the potential of ${ }^{60} \mathrm{Co}$ production in $\mathrm{N}$-Reactor, a defense production reactor at Hanford that has been shut down since early 1988, showed that it is possible to produce up to $8 \mathrm{MCi} / \mathrm{yr}$ with small impacts on the operations of the reactor. At less than a $2 \mathrm{MCi} / \mathrm{yr}$ production leve1, it would not be necessary to add enrichment to the fue 1 . Production of cobalt could be beneficial in lengthening reactor lifetime by flattening the flux levels in the reactor. Irradiation tests with cobalt in $\mathrm{N}$-Reactor have established that the cobalt activity would be about $35 \mathrm{ci} / \mathrm{g}$ after a 1-year irradiation. The cobalt could be removed from the reactor at any time to obtain any desired activity level.

It has been estimated that a commercjal power reactor (1000 MWe) could produce about 10 to $30 \mathrm{MCi} / \mathrm{yr}$ of cobalt (Sande and Libby 1976). However, production of $100 \mathrm{Ci} / \mathrm{g}$ cobalt may take up to 5 years in the light water reactors (LWRs) and may impact the operating license of the facility. Cobalt production by a commercial reactor may become more likely as the need for cobalt increases, as the economics of production become more attractive, and as licensing questions are addressed.

\subsection{SPENT FUEL}

Commercial spent fuel is a candidate for irradiation source applications because it contains the desired gama emitters and is available in large supply at little cost. However, it also contains neutron-emitting isotopes. To prevent the formation of neutron-activated material during irradiation, it is necessary to filter out the neutrons. Neutrons may be filtered by thermalizing or first slowing down the neutrons with a moderator, such as paraffin, and then capturing the thermal neutrons in an absorber, such as cadmium. The gamma flux is only slightly affected by these materials and the majority of gamma emitters will be useful for irradiation applications. The major emitters in spent fuel are ${ }^{137} \mathrm{Cs},{ }^{134} \mathrm{Cs}$, and ${ }^{60} \mathrm{Co}$. Other isotopes such as ${ }^{106} \mathrm{Ru}$, 
${ }^{125} \mathrm{Sb},{ }^{154} \mathrm{Eu}$, and ${ }^{155} \mathrm{Eu}$ are also significant gamma emitters. The strength of the gamma radiation is a strong function of the time from discharge of the spent fuel from the reactor. The inventory of cesium in spent fuel at the end of 1983 and projected for 2020 is shown in previous Table 5.2. It can be noted that the $703 \mathrm{MCi}$ of cesium in the spent fuel inventory at the end of 1983 is about ten times that in the ${ }^{137}$ Cs capsules at Hanford.

The use of spent fuel will incur several additional considerations, including: 1) safeguards issues, because it contains plutonium; 2) the lower specific activity of the spent fuel compared to the cesium and cobalt sources; and 3) increased public concern because of the fear associated with nuclear wastes. The safeguards issue could be of major economic impact on the irradiators if security had to be significantly increased because of the presence of the spent fuel. Another consideration is public perception about using food irradiated with spent fuel. This issue is addressed in Section 4.0 .

The relative activities of spent fuel, cobalt, and cesium were shown in Table 5.1. The specific activity of the cesium and cobalt in the spent fuel is about 500 times lower than the specific activity of the commercially produced cesium and cobalt. The use of spent fuel will therefore require much larger irradiators and may require higher facility capital costs. More data on this will be needed to quantify the difference in capital and operating costs between facilities that use spent fuel or those that use cesium or cobalt sources.

The basic characteristics of fuel assemblies for typical pressurized water reactors (PWRs) and boiling water reactors (BWRs) are shown in Table 5.6. The characteristics of spent fuel assemblies vary from reactor to reactor and may change with time and operational experience for a specific reactor. The spent fuel is contained in numerous rods of about $1 \mathrm{~cm}$ diameter and about $4 \mathrm{~m}$ in length. A PWR assembly 10 years out of reactor would contain about 40,000 $\mathrm{C} i$ of cesium and a BWR assembly about $15,000 \mathrm{Ci}$.

Without reprocessing or separation of the cesium, spent fuel would be one of the major alternative sources of gamma radiation and should be further evaluated particularly if the need for irradiation sources exceeds the available supply of cesium and cobalt. 
TABLE 5.6. Physical Characteristics of Typical Light Water Reactor Fuel Assemblies (a)

\begin{tabular}{|c|c|c|}
\hline Characteristics & $\begin{array}{c}\text { Pressurized } \\
\text { Water } \\
\text { Reactor } \\
\end{array}$ & $\begin{array}{l}\text { Boiling Water } \\
\text { Reactor }\end{array}$ \\
\hline Fuel element array & $17 \times 17$ & $8 \times 8$ \\
\hline Assembly total wt., $\mathrm{kg}$ & 657.9 & 319.9 \\
\hline Uranium/assembly, kg & 461.4 & 183.3 \\
\hline $\mathrm{UO}_{2} /$ assembly, $\mathrm{kg}$ & 523.4 & 208.0 \\
\hline Zircaloy/assembly, kg & $108.4(b)$ & $103.3(\mathrm{c})$ \\
\hline Hardware/assembly, kg & $26.1^{(d)}$ & $8.6(\mathrm{e})$ \\
\hline Total meta]/assembly, $\mathbf{k g}$ & 134.5 & 111.9 \\
\hline Fue 1 element $0 \mathrm{D}, \mathrm{cm}$ & 0.950 & 1.252 \\
\hline Fuel elements/assembTy & 264 & 63 \\
\hline Nominal volume/assembly, $\mathrm{m}^{3}$ & $0.186(f)$ & $0.0864(f)$ \\
\hline Active fuel length, m & 3.658 & 3.759 \\
\hline Fue] element length, m & 3.851 & 4.064 \\
\hline Fuel assembly length, m & 4.059 & 4.470 \\
\hline Cross section, $\mathrm{cm}$ & $21.4 \times 21.4$ & $13.9 \times 13.9$ \\
\hline
\end{tabular}

(a) Source: DOE/RW-0006 Rev 2 (1986), p. 36.

(b) Includes Zircaloy control-rod guide thimbles.

(c) Includes Zircaloy fuel-element spacers and fuel channel.

(d) Includes stainless steel nozzles and Inconel-718 grids.

(e) Includes stainless steel tie-plates, Inconel springs and plenum springs.

(f) Based on overa 71 outside dimensions.

\subsection{RADIATION-GENERATING EQUIPMENT}

The basic radiation-generating machine is simply an electron accelerator or beta ray generator. The major concerns with radiation-generating machines have been the efficiency of the machines, their reliability, the penetration depth of the radiation, and heat generation during the irradiation.

The efficiency of the machines (electrical energy to electron beam energy) increases with the accelerating voltage. For example, at $5 \mathrm{MeV}$ the efficiency is about $6 \%$, but at $10 \mathrm{MeV}$ it increases to about $18 \%$ and is more 
attractive. However, as the voltage increases so does the potential of inducing radioactivity in the product that is being treated. Currently, the voltage limit is $5 \mathrm{MeV}$ for $\mathrm{x}$-rays and $10 \mathrm{MeV}$ for electrons (U.S. Department of Health and Human Services 1986).

Because the radiation is generated by a machine, and machines can and do fail and need repair, the availability of machine-generated radiation is less reliable than that of gamma source materials. Availability is a significant concern in production facilities. Machine designs are being improved, and operating efficiency is also improving.

Electrons have limited penetrating capability compared with the gamma rays from cesium or cobalt. However, with two-sided irradiations and 12-MeV electrons (above current 1 imits), a product that is up to $10-\mathrm{cm}$ thick with the density of water can be treated. Since many commercial products have densities from 0.3 to 0.5 times that of water, products up to $40 \mathrm{~cm}$ thick can potentially be irradiated. The penetration ability of the electron beam is directly proportional to the accelerating voltage. With current limits for treatment of food products, the penetration depths would be limited to lower values of about $10 \mathrm{~cm}$.

Electron beam irradiators are very suitable for grain or other bulk products that can be moved past the beam in a thin stream. For example, this type of system has been used in Odessa, Russia for grain disinfestation since $1980\left(\mathrm{CH}_{2} \mathrm{M}-\mathrm{Hill} 1988\right)$, and in South Africa to treat dried sewage sludge and chicken litter (Scott 1986). Nine electron accelerators of the 460 machines in worldwide use are being used for food processing, and about ten companies are potential machine suppliers $\left(\mathrm{CH}_{2} \mathrm{M}-\mathrm{Hi} 11\right.$ 1988).

A final concern for some materials with electron irradiators is the heat buildup within the product during the irradiation. For example, a product subjected to a dose of $2.5 \mathrm{Mrad}$ will typically rise in temperature 6 to $20^{\circ} \mathrm{C}$, depending on the specific heat of the material. Since the dose with electron beams is received in a short period, there is not enough time for the heat to be conducted away from the material as is the case with gamma irradiators.

The major advantages of machine-generated radiation are: 1) machines can be built as needed without the dependence on ganma source materials, 
2) the radiation source stops when the machine is turned off, and 3 ) there is increased flexibility in the application of the radiation dose.

Machines can be built without the lead times necessary to prepare cobalt for irradiation or separate cesium from the spent fue?. There is also no limit to the number of machines that can be built. The independence from gamma source materiais eliminates the necessity to transport or handie radioactive materials and the associated problems with pubiic acceptance.

The ability to turn off the radiation when the system requires maintenance or when the radiation is not needed is a significant advantage. Machines can provide a very high dose rate, which shortens the irradiation time. Since the radiation is generated by a machine, its penetration power can also be adjusted and directed to a greater extent. These capabilities are the major reasons that machine-generated radiation is now the most common method used for radiation treatment of cancer.

Machine irradiators tend to be more capital intensive than gamma irradiators for research, demonstration and small industrial-scale facilities. Large $(150 \mathrm{~kW})$ units, which can be compared to a $15-\mathrm{MCi}$ isotope facility, have been designed but have not been put into commercial service.

Electron beam accelerators are finding increased use in industrial and medical applications. In industrial applications, the accelerators are a substitute for thermal energy. The following are estimated ratios of energy required (thermal/electrical power for electron beam) to accomplish the desired effect: curing of coatings on metal (85/1), polymerizing impregnated wood $(20$ to $50 / 1)$, cross-linking of polyethylene (2/1), bulk cure of polyesters (5/1), and sterilization of medical products (as high as $40 / 1$ ). With these potential efficiencies and the costs for energy, it seems likely that machine-generated radiation will continue to find increased use and development (Ramler 1982). 


\subsection{APPLICATIONS FOR BYPRODUCTS OTHER THAN GAMMA EMITTERS}

This section of the report discusses potential beneficial uses of byproducts other than cesium that would be available if spent fuel were processed. Applications of the major products uranium and plutonium are not considered. Additional details on the applications for byproducts are in Appendix $\mathrm{C}$.

Nearly 500 isotopes are produced in nuclear fuel by fission and neutron activation. Numerous other isotopes can be produced by neutron activation of special target materials. However, discussion of those isotopes is beyond the scope of this report. The major current candidate isotopes can be grouped into four major categories shown below: 1) those which produce heat and power, 2) those which have unique or special value, 3) those useful as targets for production of other elements, and 4) those which are useful for luminescence applications. Discussion of specific isotopes follows.

\begin{tabular}{|c|c|c|c|}
\hline $\begin{array}{c}\text { Radioisotopes } \\
\text { for Heat } \\
\text { and Power }\end{array}$ & $\begin{array}{l}\text { Special Value } \\
\text { and Unique } \\
\text { Elements } \\
\end{array}$ & $\begin{array}{l}\text { Target for } \\
\text { Production of } \\
\text { other Elements }\end{array}$ & $\begin{array}{l}\text { Luminescence } \\
\text { Applications }\end{array}$ \\
\hline $\begin{array}{l}\text { strontium-90 } \\
\text { krypton- } 85 \\
\text { promethium- } 147 \\
\text { pluton ium-238 } \\
\text { curium- } 244\end{array}$ & $\begin{array}{l}\text { americium-241 } \\
\text { technet ium-99 } \\
\text { ruthenium } \\
\text { rhodium } \\
\text { palladium } \\
\text { krypton } \\
\text { xenon }\end{array}$ & $\begin{array}{l}\text { neptuni um-237 } \\
\text { americium-241 }\end{array}$ & $\begin{array}{l}\text { krypton- } 85 \\
\text { promethium- } 147 \\
\text { tritium }\end{array}$ \\
\hline
\end{tabular}

\subsection{STRONTIUM}

Strontium-90 has a half- 1 ife of 28.8 years and decays by beta emission to $90 \mathrm{Y}$, which has a half-1ife of only 64 hours. Yttrium-90 also decays by beta emission to stable $90 \mathrm{Zr}$. Both decays are accompanied by significant $x$-ray from bremsstrahlung conversion, which requires shielding. The decay sequence yields 0.93 watts of energy per gram of ${ }^{90} \mathrm{Sr}$. Thus ${ }^{90} \mathrm{Sr}$, with a relatively long half-life, makes an excellent energy source. Typical fission product strontium is a mixture of ${ }^{88} \mathrm{Sr}$ and ${ }^{90} \mathrm{Sr}$. The ${ }^{88} \mathrm{Sr}$ is stable and dilutes the ${ }^{90} \mathrm{Sr}$ activity by a factor of about two. The thermal energy can be converted to electrical energy by several methods for different applications. 
Strontium-90 sources have been used to provide electrical power for remote weather stations, military equipment and control systems, remote surveillance stations, navigational aids, and remote emergency power. Strontium-90 sources can also be used for heat sources. In the Arctic, heat is needed to keep water and sewage (utilities) from freezing. Strontium sources could provide a stable long-term minimum maintenance source of heat for these applications. Strontium could also be used for heaters that keep the oil in petroleum tanks warm and pumpable (fluid). Strontium sources have also been proposed for use in secondary oil recovery. In this application, the sources would provide underground heat to reduce $0 i 1$ viscosity and stimulate oil recovery. The relatively long half-life is very useful for this application. Additional uses of ${ }^{90} \mathrm{Sr}$ have also been considered, some of which are discussed in Appendix $C$.

\subsection{KRYPTON}

Krypton- 85 has a half-life of 10.7 years and decays to stable ${ }^{85} \mathrm{Rb}$ by beta emission and some low yield gammas. The heat produced is $0.62 \mathrm{~W} / \mathrm{g}$, which makes $85_{\mathrm{Kr}}$ a useful heat source. Its beta energy can be used to produce 1 ight.

Krypton sources have been under investigation for many years. Tritium lights have been developed and are being tested for runway 1 ights, marine navigational aids, and roadway and safety lighting, but $85 \mathrm{Kr}$ could potentially be used in place of tritium if some additional shielding were provided for the gamna emission. Krypton sources can al so be used as an energy source for small isotopic batteries. Krypton uses could be similar to some of those identified for ${ }^{90} \mathrm{Sr}$ sources and may also include power supplies for use by biologists for tracking whales, sharks, seals and other large animals. Krypton power supplies may power telephone repeaters and other communications equipment. There are some military applications with needs for the 5 to 10 year lifetime of krypton power supplies. Because of krypton's inert nature, it may also have applications in nondestructive testing and has been used in leak detection, crack detection, and gauging applications. 


\subsection{NOBLE METALS}

Over $94 \%$ of the noble metals (ruthenium, rhodium, and palladium) used in the U.S. are imported. All are relied upon as catalysts for many strategic products. Fission product metals could be used for many of these applications in direct replacement. Some radioactivity is associated with the fission product metals and either isotopic purification or long-term aging would be needed for unrestricted use of the metals. Some successful tests have been made with fission product rhodium alloyed with platinum as a catalyst for manufacture of nitric acid. No detectable carry-over of activity was noted in the product stream.

\subsection{OTHER ISOTOPES}

As can be noted in Table 6.1, there are other isotopes that have potentially useful applications. Isotopes and potential applications are discussed in greater detail in Appendix $C$ and sumarized below.

The only known source of technetium is from spent fuel. Technetium has shown promise as a catalyst and an alternative to platinum for several applications. It has also shown superior performance as a corrosion inhibitor.

Plutonium-238 can be obtained from neutron irradiation of ${ }^{237} \mathrm{~Np}$ and neutron irradiation of $241_{A m}$, which decays with short half-life $\beta$ and $\alpha$ emissions to ${ }^{238} \mathrm{Pu}$. Plutonium-238 has found use as a heat and power source. Plutonium-238 is an alpha emitter and can be easily shielded. It has been used as a power supply for pacemakers and for space nuclear power systems.

Americium-241 is used in small quantities in smoke detectors.

Xenon is a high-yield fission product that decays rapidly to nonradioactive xenon, which is scarce as a natural element. Xenon was tested very successfully as an anesthetic over 30 years ago. It also serves as a filler gas in $x$-ray tubes and produces a spectrum that is used in laser applications. 
TABLE 6.1. Current and Potential Usage of Byproducts from Spent Fuel Application Current

Potential 1995

Remote power

Tracers for research and diagnostics

18,000 watts $(a)$

TBD (b)

70,000 watts

TBD

Self powered lights (tritium or ${ }^{85} \mathrm{Kr}$ )

- Runways

- Marine navigational aids

- Roadways and safety lighting

Nondestructive testing $\left({ }^{85} \mathrm{Kr}\right)$

Xenon for anesthesia and other uses

Arctic utility maintenance and sewage treatment $\left({ }^{90} \mathrm{Sr}\right)$

Enhanced oil recovery ( ${ }^{90} \mathrm{Sr}$ )

$180,000 \mathrm{Ci}$

0

$100,000 \mathrm{Ci}$

$20,000,000 \mathrm{Ci}$

$1,000,000 \mathrm{Ci}$

$1,000,000 \mathrm{Ci}$

$8,600 \mathrm{Ci}$

$500,000 \mathrm{Ci}$

Total produced

could be used

Catalysts and noble metal applications

Corrosion inhibitor (TC)

0

0

0 could be used

0
$7,500,000 \mathrm{Ci}$

$3,700,000 \mathrm{Ci}$

Tota1 produced

TBD

(a) 18,000 watts of electrical power would require $52 \mathrm{MCi}$ of $90 \mathrm{sr}$ with $20 \%$ thermal efficiency.

(b) $\mathrm{TBD}=\mathrm{To}$ Be Determined based on further data and research.

It is expected that many new and unique applications for isotopes and elements from spent fuel would be identified if they were available in commercial-scale quantities at reasonable prices. Currently, development of applications is limited by the availability of materials.

\subsection{ESTIMATED USE OF BYPRODUCTS}

A summary of current use of products and potential use by 1995 is contained in Table 6.1. This table includes most of the uses identified in the preceding sections $(6.1-6.4)$. 


\subsection{COST ANALYSIS AND ASSESSMENT OF ALTERNATIVES}

In this section, the capacities of the four alternatives identified in Section 5.0 are compared to the projected need discussed in Section 3.0. The relative values for cesium sources are compared to costs for cobalt sources, costs for waste management and byproduct recovery are reviewed, and other major cost issues are discussed. Several sources will likely need to be developed to provide the long-term supply of gamma sources. Reprocessing of spent fuel could become an economically viable option if potential fuel recycle component/byproduct values are realized.

\subsection{PROJECTION OF GAMMA SOURCES AND OEMANDS}

In this section, the projected sources and demands for gamma materials are compared to identify those options that will be useful in meeting future demands. It was noted in Section 3.0 that the need for gamma source materials during the next 3 years is expected to be about $67 \mathrm{MCi}$ of ${ }^{60} \mathrm{Co}$ equivalent, based on a survey of the current users of gamma source materials. This usage would result in an inventory in 1990 of $110 \mathrm{MCi}$ of ${ }^{60} \mathrm{Co}(550 \mathrm{MCi}$ of ${ }^{137}$ Cs equivalent). This projection yields a compound growth rate of $13 \%$ when considering the decay in the current and future sources. Much higher growth rates ( $30 \%$ annually) have been projected for the irradiation industry (Gidwani 1986).

Beyond 1990, two different scenarios for the growth of needs for gamma materials are used. The first, the minimum use alternative, considers future growth beyond 1990 to be 1 imited to the growth in the use of medical supplies, which is currently about $5 \%$ annually. This alternative assumes no increased penetration of the market.

The second scenario uses the assumptions of continued growth of the medical supply industry at the $5 \%$ annual rate and an additional growth of $5 \%$ annually in treatment of additional quantities of medical products until $90 \%$ of the total medical product are treated by irradiation in 1996. This alternative further assumes that the treatment of food will reach its potential of $75 \mathrm{MCi}\left({ }^{60} \mathrm{Co}\right)$ (estimated in Section 3.0) in 1996 also. A high initial growth $(60 \%$ annual1y) is projected, followed by step decreases in the rate of growth 
every 2 or 3 years. This projection results in $75 \mathrm{MCi}$ need in 1996. Beyond 1996, the growth rates for both medical products and food treatment decrease to $5 \%$ annualiy.

The range of potential needs for gamma materials based on the two scenarios is shown in Figure 7.1. Additional details of the calculations are contained in Appendix D.

Three production scenarios are also included in Figure 7.1. The first scenario assumes that there is little change in current U.S. production capacity and that additional cobalt from Canada is limited to $20 \mathrm{MCi} / \mathrm{yr}$. It can be noted that this does not provide sufficient gamma source materials for even the minimum growth scenario.

The second production scenario assumes that all alternatives are used for production of gamma source materials: 1) U.S. ${ }^{60}$ Co production is increased to $5 \mathrm{MCi} / \mathrm{yr}$ by use of a DOE reactor or a commercial reactor; 2) Cobalt imports are $50 \%$ of AECL production capacity (Fraser 1985) up to a limit of $50 \mathrm{MCi}$; and 3) Cesium is produced from Hanford defense wastes and

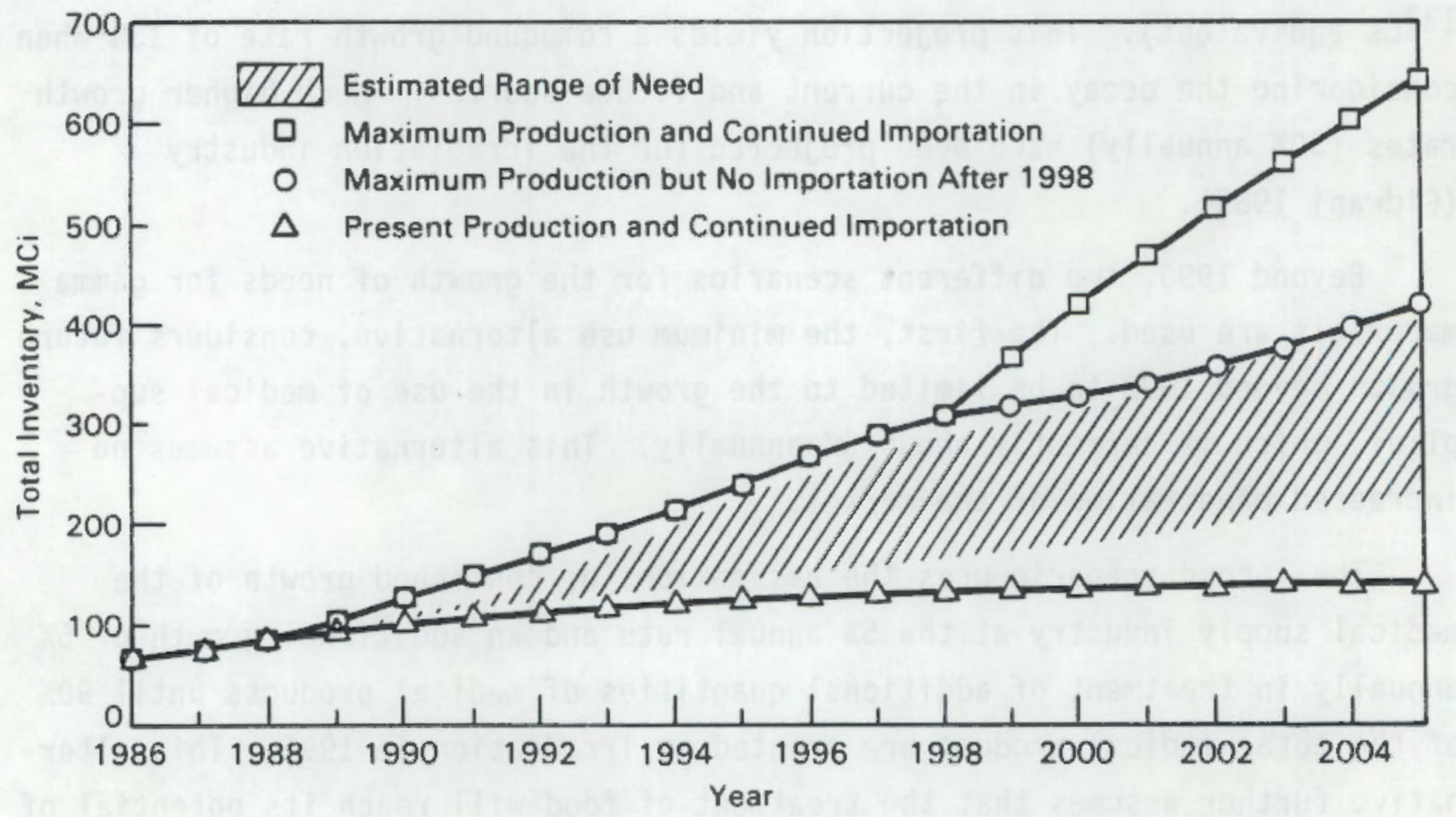

FIGURE 7.1. Comparison of Gamma Source Supply and Demand (Values shown as ${ }^{60}$ Co plus ${ }^{60}$ Co equivalent) 
from a $2500 \mathrm{MTU} / \mathrm{yr}$ reprocessing plant for commercial spent fuel. The combination of all of these sources will provide adequate material for the maximum growth industry noted previously. Beyond 1998, when the commercial reprocessing plant is in full operation, the availability of gamna source material increases far above the maximum projected requirement.

The third scenario calls for the elimination of imports of cobalt after 1998. Production is provided by all other sources described in the second scenario. The third scenario provides sufficient source material for the maximum growth alternative and indicates one means of reducing U.S. dependence on imports.

A fourth scenario was calculated with the maximum need supplied solely by imports from Canada. To meet the maximum need, imports would have to increase to $75 \mathrm{MCi}$ annually by 2005 . In 2005, cobalt decay would be about $55 \mathrm{MCi}$, which indicates that use is 1 imited primarily to replacement of ${ }^{60} \mathrm{Co}$ in service.

The above analysis does not include the direct use of spent fuel in irradiators or machine-generated irradiation. These sources should be considered, especially if reprocessing cannot be implemented within the next few years and food irradiation begins to realize some of its potential.

\subsection{VALUE OF CESIUM FROM SPENT FUEL}

The value of cesium as a replacement for cobalt has been recently studied (Bloomster 1985). The value of cesium was compared to that of cobalt in a series of irradiators for different products. It was found that cesium was worth about $40 \%$ of the price of cobalt. For example, with cobalt costs at $\$ 1.20$ per curie, cesium would be worth about $\$ 0.48$ per curie.

\subsection{ECONOMIC COMPARISON OF BYPRODUCT SOURCES}

The estimated costs of four different spent fuel disposal options are compared in this section. All options are based on an annual processing rate of $2500 \mathrm{MTU}$, with a total of 70,000 MTU. This is a preliminary evaluation based on limited cost information and is intended merely to provide a perspective on the desirability of further, more comprehensive analysis. The 
reference option for the comparison is government packaging of the spent fuel at the monitored retrievable storage facility (MRS) in a standard canister and then disposing of the consolidated spent fuel in a basalt repository. The second option is to process the spent fuel by thermal outgassing and to recover the volatile materials before encapsulating and disposing of the fuel (Section 5.1.1.1). For the therma] outgassing option, low-return financing (10\% annual charges on capita1) is assumed. The third and fourth options are a full reprocessing scheme at a centra] facility with two different financing options. The third option is low-return financing (10\% annual charges on capital, for example government sponsored), and the fourth option (highreturn financing -- comercial) is based on an annual charge of $32 \%$ of capitaT (INFCE 1980). Both reprocessing options assume recovery of the uranium, plutonium, cesium, and other fission products before solidifying and disposing of the waste products (Section 5.1.1.2). Improved waste treatment for the facilities is considered. The cost estimates are all based on 1986 dollars and are very preliminary.

Table 7.1 shows a comparison of the estimated costs and recovery value for each of the four spent fuel disposal options. Low-return financing of reprocessing is shown to be potentially economically viable, but the other by-product separation options all show significant net losses. Reprocessing is economically superior to thermal outgassing.

The cost estimates for the four alternatives are broken down in Table 7.2. The basic costs for the reprocessing alternatives were taken from the Internationa] Fuel Cycle Evaluations (INFCE 1980) and adjusted for the 2500 MTU capacity and the current costs of construction. The method is considered conservative because $40 \%$ is added to capital costs for owners charges during construction and charges on direct capital during construction. Also, an $80 \%$ capacity factor is used in calculating throughput. Both the low-cost and high-cost financing alternatives were considered and were escalated to 1986 dollars. The $10 \%$ or $32 \%$ fixed charges provide for the payment of interest and repayment of the principal for financed capital costs and are representative of government and private financing. Additional capital and operating costs were added for the additional facilities for the separation of the byproducts and for waste treatment, transportation, and disposal. The 
IABLE 7.1. Cost Comparison of Spent Fuel Outgassing or Reprocessing Versus Spent Fuel Disposal in the United States(a)

\begin{tabular}{|c|c|c|c|c|c|c|c|}
\hline \multirow[b]{2}{*}{ Facility } & \multirow{2}{*}{$\begin{array}{l}\text { Total } \\
\text { System } \\
\text { Cost, } \\
\mathbf{s} / \mathrm{kg} \\
\end{array}$} & \multicolumn{2}{|c|}{$\begin{array}{c}\text { Recovery Vaiue } \\
\text { of Byproducts, } \\
\$ / \mathrm{kg}\end{array}$} & \multicolumn{2}{|c|}{$\begin{array}{l}\text { Net System } \\
\text { Cost, } \$ / k g \\
\text { (total system } \\
\text { cost minus } \\
\text { recovery value) }\end{array}$} & \multicolumn{2}{|c|}{$\begin{array}{c}\text { Potential } \\
\text { Net Saving } \\
\text { <loss Compared } \\
\text { to Spent } \\
\text { Fuel Disposal, } \\
\text { \$/kg } \\
\end{array}$} \\
\hline & & Minimum & Maximum & Minimum & Maximum & Minimum & Maxinum \\
\hline Spent Fuel Disposal & 260 & 0 & 0 & 260 & 260 & - & - \\
\hline Thermal outgassing & 405 & 45 & 50 & 360 & 355 & $(100)$ & (95) \\
\hline $\begin{array}{l}\text { Reprocessing with } \\
10 \% \text { annual charges }\end{array}$ & 455 & 125 & 510 & 330 & (55) & $(70)$ & 315 \\
\hline $\begin{array}{l}\text { Reprocessing with } \\
32 \% \text { annual charges }\end{array}$ & 960 & 125 & 510 & B35 & 450 & $(575)$ & (190) \\
\hline
\end{tabular}

(a) Values rounded to nearest $\$ 5 / \mathrm{kg}$ of uranium processed.

waste treatment costs were taken from recent studies for optimized waste treatment facilities (Ross et al. 1985). The transportation costs were estimated based on the number of shipments and typical costs for casks, maintenance, and shipping of both the HLW and transuranic waste (TRUW) to a repository. The potential savings from the reduced heat and volume of the vitrified wastes compared with the spent fuel wastes is about $25 \%$ of the spent fuel disposal costs. The costs for the ultimate disposal of the byproducts have not been included in this analysis. If the byproducts are used for at least one and possibly several half-lives, disposal costs would not significantly impact overall costs on a discounted cost basis.

A thermal outgassing plant has not been designed, therefore the cost estimates are order-of-magnitude estimates based on costs of the reprocessing plant and the spent fuel handling facility. The cost basis is the same as reprocessing with $40 \%$ capital charge for owner charges during construction and charges on capital during construction. An $80 \%$ capacity factory is al 50 applied. The transportation and disposal costs are higher than the spent fuel costs because of the increased volume that results from shearing the assemblies and immobilizing them randomly into a matrix. It was assumed that 


\section{IABLE 7.2. Costs for Byproduct Extraction}

\begin{tabular}{|c|c|c|c|c|c|c|c|c|c|c|c|}
\hline \multicolumn{3}{|c|}{$\begin{array}{c}\text { 10\% Annual Charges } \\
\text { Reprocessing Plant } \\
2500 \text { HIU/yr }\end{array}$} & \multicolumn{3}{|c|}{$\begin{array}{l}\text { 32\% Annual Charges } \\
\text { Reprocessing PIant } \\
2500 \mathrm{MIU} / \mathrm{Yr}\end{array}$} & \multicolumn{3}{|c|}{$\begin{array}{c}\text { Lox Annual Charges Thermal } \\
\text { Outgassing Piant } \\
2500 \mathrm{MIU}\end{array}$} & \multicolumn{3}{|c|}{$\begin{array}{c}\text { 10\% Anrilal Charqes Spent } \\
\text { Fuel Packaging MRS - } \\
2500 \text { MTU/rr }\end{array}$} \\
\hline $\begin{array}{c}\text { Capital } \\
\text { Cost, } \\
\text { Millions. S } \\
\end{array}$ & $\begin{array}{l}\text { Cost, } \\
\text { Millions } \\
S / \text { Year }\end{array}$ & $\begin{array}{l}\text { Unit } \\
\text { Cost } \\
\text { S/kg U }\end{array}$ & $\begin{array}{l}\text { Capital } \\
\text { Cost, } \\
\text { Millions, }\end{array}$ & $\begin{array}{l}\text { Cost, } \\
\text { Millions } \\
\text { S/year }\end{array}$ & $\begin{array}{l}\text { Unit } \\
\text { Cost. } \\
\text { S/kg } 4\end{array}$ & $\begin{array}{l}\text { Capital } \\
\text { Cost, } \\
\text { atilions, }\end{array}$ & $\begin{array}{l}\text { Cost, } \\
\text { Millions } \\
\text { S/year }\end{array}$ & $\begin{array}{l}\text { Unit } \\
\text { Cost. } \\
\text { I/kg U }\end{array}$ & $\begin{array}{l}\text { Capital } \\
\text { Cost, } \\
\text { Millons, }\end{array}$ & $\begin{array}{l}\text { Cost } \\
\text { Millions } \\
\text { s/year }\end{array}$ & $\begin{array}{l}\text { Unit } \\
\text { Cost } \\
\text { S/kg U } \\
\end{array}$ \\
\hline 2,183 & 125 & 215 & 2,183 & 125 & 551 & 1,700 & 100 & 169 & 1,000 & 73 & 85 \\
\hline
\end{tabular}

construction and operations

CS Recovery from offgas

Koble Metal

Recovery

Pu Solidification

CS and St Recovery

TRU and HA

Waste Treatment

HLW Solidification

HLW Iransportation

HLW Oisposal

TOTAL

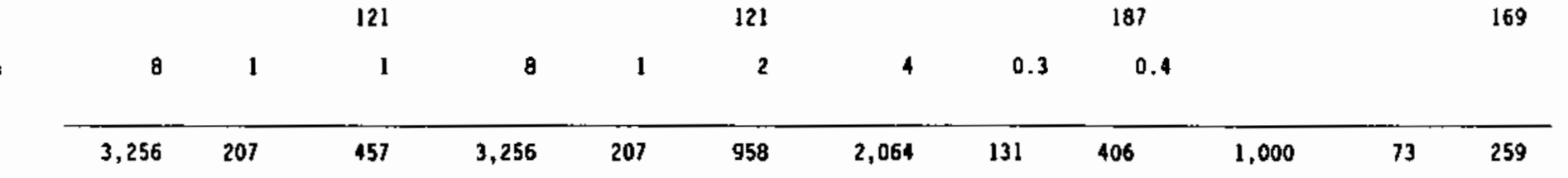


the volumes would be about twice that of the unsheared spent fuel. Heat loadings, however, are lower than the spent fuel heat loadings because of the removal of the cesium.

The costs for a monitored retrievable storage (MRS) facility for the direct disposal of the spent fuel are taken from Conner and Wilmont (1986). A $40 \%$ capital charge is also made. However, no capacity factor has been applied because the original design of the MRS was at -3600 MTU/yr assumptions allow all of the alternatives to have a central treatment facility and common shipping distances. The MRS provides for the receipt of the spent fuel from the reactors and its consolidation into a more dense configuration. Transportation costs for all the alternatives are for transportation from the central facility to the basalt repository only.

The values of the materials recovered from the thermal outgassing and reprocessing are shown in Table 7.3. The quantity of materials recovered is based on Tables 5.4 and 5.5, respectively. The values of the noble metals ruthenium, rhodium, and palladium were based on the market prices as of January 1987. (a) The market prices of the noble metals were assumed to be one-half of the commercial prices because of the slight amount of radioactivity in the metals. The values of xenon and strontium are based on current selling prices. The price for uranium accounts for the extra $235_{U}$ and $236_{U}$ (a uranium penalty) in the recovered uranium, with $\mathrm{U}_{3} \mathrm{O}_{8}$ prices as of December 1986. The lower values are the current spot market price, whereas the higher value is the long-term U.S. government price. The maximum plutonium value is based on its value as a substitute for uranium in the LWR fuel cycle (OCED 1985), whereas the minimum value assumes that interim storage costs (the costs of storage until it is recycled) will equal recycle value. The value for cesium is from Section 7.2 and is for processed and encapsulated material. The cesium value per MT of spent fuel is about $1 / 4$ to $1 / 2$ that of the uranium value, indicating a significant economic value. Comparison of byproduct value (Table 7.3 ) and costs (Table 7.2 ) shows that cesium is cost

(a) It should be noted that if the noble metals are left in the HLW, their concentrations would far exceed those found in nature. This might represent an attractive mine source at some time in the future when noble metal supplies become scarce. 
IABLE 7.3. Value of Uranium, Plutonium, and Fission Products in Spent Fuel(a)

\begin{tabular}{|c|c|c|c|c|c|c|c|}
\hline \multirow[b]{2}{*}{ Material } & \multirow{2}{*}{$\begin{array}{l}\text { Quantity of } \\
\text { Byproduct, } \\
\text { Unit/kg of } \\
\text { Spent Fuel }\end{array}$} & \multicolumn{2}{|c|}{$\begin{array}{c}\text { Value Per Unit, } \\
\text { (Gram or Curie), } \\
\$\end{array}$} & \multicolumn{2}{|c|}{$\begin{array}{l}\text { Chemical } \\
\text { Processing } \\
\text { Value, } \$ / \mathrm{kg}\end{array}$} & \multicolumn{2}{|c|}{$\begin{array}{l}\text { Thermal } \\
\text { Processing } \\
\text { Value, } \$ / \mathrm{kg}\end{array}$} \\
\hline & & Low & High & Low & High & Low & High \\
\hline U & $960 \mathrm{~g}$ & 0.07 & 0.17 & 70 & 160 & & \\
\hline Pu & $11 \mathrm{~g}$ & 0.00 & 15.00 & 0 & 165 & & \\
\hline $\mathrm{Kr}$ & $4.4 \mathrm{Ci}$ & 0.50 & 1.50 & 2 & 7 & 2 & 7 \\
\hline$X e$ & $4.6 \mathrm{~g}$ & 0.70 & 0.70 & 3 & 3 & 3 & 3 \\
\hline Cs & $83 \mathrm{Ci}$ & 0.48 & 0.48 & 36 & 36 & 38 & 38 \\
\hline $\mathrm{Sr}$ & $53 \mathrm{Ci}$ & 0.10 & 2.00 & 5 & 96 & & \\
\hline Ru & $2 \mathrm{~g}$ & 1.44 & 1.44 & 1 & 1 & & \\
\hline Pd & $1.2 \mathrm{~g}$ & 2.11 & 2.11 & 1 & 1 & & \\
\hline $\mathrm{Rh}$ & $0.38 \mathrm{~g}$ & 19.60 & 19.60 & 4 & 4 & & \\
\hline Tc & $0.8 \mathrm{~g}$ & 2.00 & 50.00 & 1.5 & 39 & & \\
\hline Totals & & & & 124 & 512 & 43 & 48 \\
\hline
\end{tabular}

(a) No values are shown for $\mathrm{Pr}, \mathrm{Cm}, \mathrm{Np}$, or Am because current applications are limited and values are not well defined.

effective to separate once reprocessing is viable. The current DOE selling price for ${ }^{85} \mathrm{Kr}$ is $\$ 71$ per curie; however, the price assumed in Table 7.3 is representative of a market that has an adequate supply and is based on equivalent value of krypton and tritium as power sources for light applications (Section 6.2). The high current price of ${ }^{85} \mathrm{Kr}$, if used, would increase the recovered value of byproducts by $\$ 340 / \mathrm{kg}$ of spent fuel for both reprocessing and thermal outgassing, which would dramatically affect the overall economics of reprocessing or thermal outgassing, but was considered unrealistic with a major source of supply.

This table shows that byproducts can have a major impact on the economics of reprocessing. A major factor that needs further evaluation is the value placed on plutonium. The higher estimated value shown is typical of plutonium if it is recycled into a light water reactor; its actual value could be as high as five times the highest estimate if it is used in a fully developed breeder reactor fuel cycle. This utilization of plutonium could 
result in very favorable economics; however, the determination of its value for this purpose is beyond the scope of this effort. The estimated values of the other byproducts are believed to be realistic, but additional study is needed to define their values and markets more reliably. Potential markets were estimated in Table 6.1 and are of potential size to utilize most of the byproducts identified in Table 7.3. It should be noted that all of the isotopes made available may not be used or sold immediately; however, markets can only be developed as the materials are available.

\subsection{COMPARISON OF THE MAJOR ALTERNATIVES}

The major alternative options for providing gamma irradiation were identified and discussed in Chapter 5.0. They include the following:

- thermal outgassing of spent fuel

- chemical processing of spent fuel

- direct use of spent fuel

- cobalt irradiation

- machine-generated radiation.

The first three options use cesium in spent fuel as the primary gamma source but obtain it in different ways or use it directly from the spent fuel. The last two options provide gamma radiation from alternative sources.

The most important factors for comparing these options are:

- cost of providing the gamma radiation and cost of irradiation facilities (overall system economics)

- capacity of the method to produce the gamma source

- positive or negative impacts on waste management

- government involvement in estabijshing and operating the process facilities

- acceptance of the method by the public (i.e., possible problems with acceptance because of association with other nuclear activities)

- the ability to provide other byproducts in addition to gamma sources. 
A brief description of each of these considerations for each of the methods is contained in Table 7.4, which shows that no single method has advantages in all the areas considered.

Thermal outgassing does not appear to have any area of major advantage. This option would have a lower capital cost than chemical processing, but it would not make as many byproducts available and would likely have a higher unit cost.

Chemical processing provides the lowest potential price for cesium as a gamma source if a significant value is accepted for uranium and piutonium. Chemical processing also has the advantages of providing the widest variety of byproducts and reducing waste management concerns. Assuming a reasonable growth in nuclear power, either the thermal or chemical process would make available a large inventory of cesium and would thus be a major source for meeting irradiation requirements. Since chemical separation of the byproducts would increase plutonium availability, there may be a fraction of the public which could be expected to oppose the introduction and use of chemical separation methods.

Direct use of spent fuel as an irradiation source has the advantage that no special treatment of the spent fuel is required before the gamma source is available. It should be remembered that spent fuel is a dilute source compared with cesium or cobalt capsules, and the use of spent fuel will increase capital costs of facilities. The aging of the fuel as an irradiation source would simplify the interim storage and final disposal of the spent fuel. If processing is desired at a future time, the reprocessing of the aged fue 1 would also be simplified because of its lower activity and elimination of short half-life isotopes. However, public acceptance of this method could be the most difficult because of the perception of the hazards of material irradiated with commercial fuel and the need for safeguards for plutonium in the spent fuel. This could further delay the application of radiation processing. 
TABLE 7.4. Assessment of Alternatives for Providing Gamma Irradiation

\begin{tabular}{|c|c|c|c|c|c|c|}
\hline Alternative & _ costs & Production Copacity & $\begin{array}{l}\text { Kaste Managenent } \\
\text { Inoacts }\end{array}$ & $\begin{array}{l}\text { Governent } \\
\text { Involvenent }\end{array}$ & $\begin{array}{l}\text { Publ ic Acceptance } \\
\text { Issues }\end{array}$ & $\begin{array}{l}\text { Other Byproduct } \\
\text { Avail abbility }\end{array}$ \\
\hline $\begin{array}{l}\text { Thernat outgassing of spert } \\
\text { fuel }\end{array}$ & $\begin{array}{l}\text { Highest cost because capital } \\
\text { costs and waste volumes are } \\
\text { high and only limited } \\
\text { byproducts are obtained to } \\
\text { cover the costs. }\end{array}$ & $\begin{array}{l}\text { Cormercial spent fuel will } \\
\text { contain sufficient cesium for } \\
\text { most projected uses of gama } \\
\text { irradiation. }\end{array}$ & 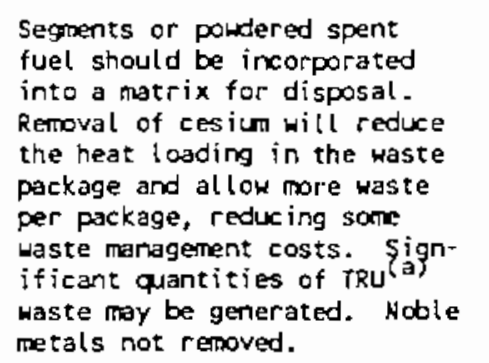 & $\begin{array}{l}\text { With current agreenents, the } \\
\text { govermert may own the spent } \\
\text { fuel and process it. The } \\
\text { goverment would retake title } \\
\text { to the wastes, uranium, and } \\
\text { plutonium. Goverment would } \\
\text { also be involved through } \\
\text { regulations and I icensing. }\end{array}$ & $\begin{array}{l}\text { The high risk perceived by } \\
\text { the, ghblic for management of } \\
\text { HLW } \text { could be transferred } \\
\text { to the gamma irradiation } \\
\text { facility and product. How- } \\
\text { ever, this could also make } \\
\text { HLW managenent more accept. } \\
\text { able then the wastes are } \\
\text { shown to have same value and } \\
\text { become more manageable by use } \\
\text { of the byproducts. }\end{array}$ & $\begin{array}{l}\text { Hould only provide the vola- } \\
\text { tile fission products. }\end{array}$ \\
\hline $\begin{array}{l}\text { Chemical processing of spent } \\
\text { tuel }\end{array}$ & $\begin{array}{l}\text { Highest operational and capi- } \\
\text { tal costs for separation and } \\
\text { waste treatment. Greatest } \\
\text { benefit fram recovery of by- } \\
\text { products and lower disposal } \\
\text { costs fram the reduced heat } \\
\text { loading and lower wotume of } \\
\text { yastes. Possible lowest by- } \\
\text { product costs and greatest } \\
\text { savings from spent fuel } \\
\text { treatment. }\end{array}$ & Same as above. & $\begin{array}{l}\text { Greatest benefit to waste man- } \\
\text { agment operations; altious re- } \\
\text { moval of the major heat pro- } \\
\text { ducers in waste and allows- } \\
\text { much higher waste content in } \\
\text { each package. Hajor quant i- } \\
\text { ties of TRU waste generated. }\end{array}$ & Same as above. & $\begin{array}{l}\text { Same as above, plus concerns } \\
\text { about the increased availa- } \\
\text { bility of plutonium for weap- } \\
\text { ons and the increased need } \\
\text { for safegurds. }\end{array}$ & $\begin{array}{l}\text { Greatest opportunity for } \\
\text { making the fission products } \\
\text { available for byproduct } \\
\text { applications. }\end{array}$ \\
\hline Direct use of spent fuel & $\begin{array}{l}\text { Increased design and fabrica- } \\
\text { tion costs for irradiators. } \\
\text { (The lower concentration of } \\
\text { gamma enitters and the need to } \\
\text { provide neutron shielding } \\
\text { would increase the size and } \\
\text { complexity of the gamma irra- } \\
\text { diat ion focilitity.) }\end{array}$ & Same as above. & $\begin{array}{l}\text { Positive benefits for waste } \\
\text { maragement. Interim storage } \\
\text { in the irradiators there } \\
\text { hastes would decay to lower } \\
\text { thernal power, therebty re- } \\
\text { ducing disposal costs. }\end{array}$ & 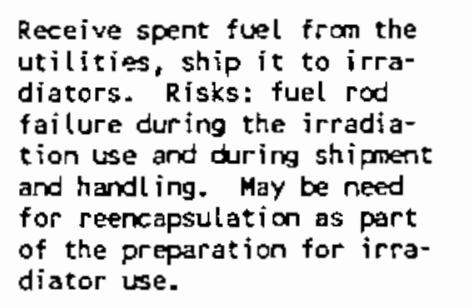 & $\begin{array}{l}\text { Hould tie irradiation di- } \\
\text { rectly to haste management } \\
\text { which some public interest } \\
\text { groups oppose. }\end{array}$ & $\begin{array}{l}\text { Spent fuel would be availa- } \\
\text { ble for future chemical } \\
\text { processing. }\end{array}$ \\
\hline $\begin{array}{l}\text { Cobalt irradiation in FFTF or } \\
\text { N reactor }\end{array}$ & $\begin{array}{l}\text { Wi thout neutron charges, costs } \\
\text { are very low. With neutron } \\
\text { charges, the cost may be } \\
\text { higher than the current } \\
\text { market. }\end{array}$ & $\begin{array}{l}\text { Without changing the mission } \\
\text { of the reactors, the produc } \\
\text { tion capacity may not be suf- } \\
\text { ficient to meet current or } \\
\text { projected U.S. needs. }\end{array}$ & 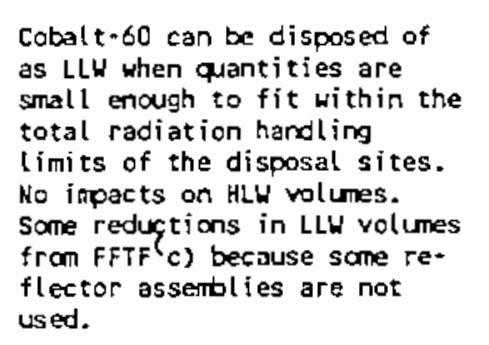 & $\begin{array}{l}\text { Low risk to goverment. Pri- } \\
\text { vate industry responsible for } \\
\text { preparation of irradiation } \\
\text { material and its distribution } \\
\text { following irradiation. }\end{array}$ & $\begin{array}{l}\text { No tie with waste managenent } \\
\text { and therefore no concern with } \\
\text { waste managenent perceptions. } \\
\text { Public acceptance yould be } \\
\text { total ly dependent on the spe- } \\
\text { cific product or appl ication. }\end{array}$ & $\begin{array}{l}\text { Hould not increase the } \\
\text { availabitity of byproducts } \\
\text { from spent fuel. }\end{array}$ \\
\hline Machine-generated radiation & $\begin{array}{l}\text { Cost effect ive for appropriate } \\
\text { products. }\end{array}$ & $\begin{array}{l}\text { Not dependent on garma source } \\
\text { materials. sources can be } \\
\text { provided wi thout l imit and } \\
\text { without long lead time. }\end{array}$ & $\begin{array}{l}\text { Ko direct inpact on waste } \\
\text { managenent. }\end{array}$ & $\begin{array}{l}\text { No goverment involvement } \\
\text { except for li censing of } \\
\text { facilitities. }\end{array}$ & $\begin{array}{l}\text { Similar to radiation used in } \\
\text { the medical field; better ac- } \\
\text { ceptance than cesilum source } \\
\text { materials. Can be turned on } \\
\text { or off fir mo control of the } \\
\text { radiation. }\end{array}$ & Same as above. \\
\hline
\end{tabular}

(a) $T R U=$ transuranic.

(b) $\mathrm{HLH}=$ high level waste.
(c) FFTF = fast flux Test Facility. 

Cobalt irradiation in FFTF or $\mathrm{N}$-Reactor at Hanford could provide an economical source of ${ }^{60} \mathrm{Co}$, provided that neutron charges are not excessive. This option would provide a U.S. supply of cobalt, but that supply would not meet a significant fraction of the current U.S. requirements without major impacts on reactor operations and increased costs. It would have the advantage of minimizing government involvement (only the irradiation is accomplished in government facilities) and the need for major capital investment. The use of other government reactors for this option needs further evaluation. Utilities would probably not be agreeable to modifying their operations to provide ${ }^{60} \mathrm{Co}$ if significant licensing changes were involved. The economic incentives to produce ${ }^{60} \mathrm{Co}$ in power reactors are limited because ${ }^{60} \mathrm{Co}$ value would be a few percent of the power generation value at current price levels. Interest will likely grow with increases in the price of ${ }^{60} \mathrm{Co}$.

Machine-generated radiation has the potential advantages of greater public acceptance because of its separation from waste management; the radiation can be turned off when not in use; the lack of need for radiation control during shipments and periods of nonuse; and public familiarity with medical $x$-ray type units. Radiation-generating machines also have the advantage of freedom from isotope supply. The major limits are the penetration capability of the beams, the lower reliability of the beams compared to the sources, the problem of heating of some materiais during processing, and capital costs of equipment and facilities. 



\section{REFERENCES}

AECL. 1986a. World List of Contract Gamma Processing Facilities. Atomic Energy Canada, Limited, Industrial Irradiation Division, Kanata, Ontario, Canada.

AECL. 1986b. World List of Industrial Gamma Irradiators. Atomic Energy Canada, Limited, Industrial Radiation Division, Kanata, Ontario, Canada.

Bloomster, C. H., et al. 1985. Potential Value of Cs-137 Capsules. PNL-5380, Pacific Northwest Laboratory, Rich] and, Washington.

Brand Group. 1986. Irradiated Seafood Products: A Position Paper for the Seafood Industry. Brand Group, Inc., Chicago, Illinois.

Bray, L. A., L. L. Burger, L. G. Morgan, and D. L. Baidwin. 1983. Thermal Release of Volatile Fission Products from Irradiated Nuclear Fuel. PNL-4488, Pacific Northwest Laboratory, Richland, Washington.

CAST 1986. Ionizing Energy in Food Processing and Pest Control: Wholesomeness of Food Treated with Ionizing Energy. ISSN 0194-4088, Council for Agricultural Science and Technology.

$\mathrm{CH}_{2} \mathrm{M}-\mathrm{Hi} 11$, S. Humpries, Jr., and J. P. Farrel1 Consultants. 1988. Options Analysis: Machine Sources for Foor Irradiation, January 1988. U.S. Department of Energy, Albuquerque Operations Office, Alguquerque, New Mexico.

Conner, C. W., and E. L. Wilmont. 1986. "Design, Cost, Schedule, and Licensing Implications of an Integrated Waste Management System." High Level Nuclear Waste Management. H. C. Burkholder (ed.), Battelle Press, Columbus, Ohio.

CRA. 1987. "Blood Irradiators." Committee on Radiation Application, Newsletter, January 1987, Atomic Industrial Forum (now U.S. Council for Energy Awareness, Washington, D.C.).

Cullen, S. C., and E. G. Gross. 1951. "The Anesthetic Properties of Xenon in Animals and Human Beings, with Additional Observations on Krypton." Science, $113: 580-582$.

"Food Irradiation Technology in the United States." Apri1 19-21, 1982. Presented at the DOE/USDA/AIBS Workshop on Low-Dose Irradiation Treatment of Agriculture Commodities, Washington, D.C.

Fraser, F. M. 1985. "Cobalt-60 Availability for Radiation Processing." Presented at the 17th Japan Conference on Radiation and Radioisotopes, September 2-4, 1985, Tokyo.

General Electric. 1977. Table of Isotopes. San Jose, California. 
Gidwani, B. 1986. Irradiation Industry Continues to Grow. Kidder, Peabody \& Co., Inc., New York, New York.

Hungate, F. P., W. F. Remath, L. R. Bunne11, and M. F. Gillis. 1974. "Chronic Blood Irradiation--A New Approach." BNWL-SA-5064, Pacific Northwest Laboratory, Richland, Washington.

INFCE. 1980. "International Nuclear Fuel Cycle and Evaluation--Reprocessing, Plutonium Handling, Recycling." INFCE Working Group 4, International Atomic Energy Agency, Vienna.

Jackson, R. R. 1976. "Hanford Waste Encapsutation: Strontium and Cesium." Nuclear Technology, 32:10-15.

Josephson, E. S., and M. S. Peterson (eds.). 1982. Preservation of Food by Ionizing Radiation. CRC Press, Boca Ranton, Florida.

Kirk-0thmer. 1980. "Hydrogen-lon Activity to Laminated Materials, Glass." Encyclopedia of Chemical Technology, 3rd Edition, Vol. 13, John Wiley \& Sons, New York.

Lederer, C. M. and V. S. Shirley (eds.). 1978. Table of Isotopes. 7th ed. Wiley-lnterscience, New York, New York.

Ministry of Agriculture, Fisheries, and Food. 1986. Report on the Safety and Wholesomeness of Irradiated Foods. Department of Health and Social Services, Northern Ireland.

Molton, P. M. 1987. Irradiation Preservation of Seafood Literature Review. PNL-6311, Pacific Northwest Laboratory, Richland, Washington.

Moy, J. H. (ed.). 1983. Radiation Disinfestation of Food and Agricultural Products. University of Hawait Press, Honolulu, Hawaii.

NUS Corporation. 1981. "A Survey of Large Scale Gamma Irradiators in the United States." Rockville, Maryland.

OCED. 1985. The Economics of the Nuclear Fuel Cycle. Organization for Economic Co-Operation and Development, Nuclear Energy Agency, Paris, France.

0lguin, L. J., G. E. Benedict, and R. G. Wilbourn. 1982. Thermal Outgassing Engineering Study. Prepared for Pacific Northwest Laboratory by General Atomic Company, San Diego, California. Information reported in L. A. Bray, L. L. Burger, L. G. Morgan, and D. L. Baldwin. 1983. Thermal Release of Volatile Fission Products from lrradiated Nuclear Fuel, Appendix B.

PNL-4488, Pacific Northwest Laboratory, Richland, Washington.

Ouwerkerk, T. 1982. An Overview of the Most Promising Industrial Applications of Gamma Processing. Proceedings of the International Symposium on Applications and Technology of lonizing Radiations. College of Science King Saudi University, Riyadh, Saudi Arabia. March 12-17, 1982. 
Overbeek, W. P. March 21-23, 1966. "Production of Radioisotopes in Production Reactors." In: Large Scale Production and Application of Radioisotopes in Proceedings of the ANS National Topical Meeting. Augusta, Georgia, pp. 1066, Vol. 1 .

Packaging Digest. 1986. "Food Irradiation, the Giant Stir." Packaging Digest, June 1986, pp. 40-42.

Ramler, W. J. 1982. "Machine Sources." Preservation of Food by Ionizing Irradiation. Volume 1 , CRC Press.

Rhodes, A. A. (ed.). 1986. Irradiation Disinfestation of Dried Fruits and Nuts, June 1986. Final report from the U.S. Department of Agriculture to the U.S. Department of Energy under Interagency Agreement Number DE-A104-83AL 24327.

Ross, W. A., K. J. Schneider, J. L. Swanson, K. M. Yasutake, and R. P. Allen. 1985. "Preliminary Analysis of Treatment Strategies for Transuranic Wastes from Reprocessing Plants." PNL-5130, Pacific Northwest Laboratory, Richland, Washington.

Sande, W. E. and R. A. Libby. August 1976. Potential Sources for Radiation Treatment of Food. BNwL-2095, Pacjfic Northwest Laboratory, Richiand, Washington.

Sandia Irradiator for Dried Sewage Solids. October 18-19, 1978. Seminar Proceedings and Dedication, Albuquerque, New Mexico. SAND79-0182, Sandia Laboratories, Albuquerque, New Mexico.

Scott, P. 1986. "Waste Recycling the Beta-Way." South African Digest, April 25, 1986, p. 356.

Semling, Harold, V. October 1984. "Government and Industry Interest in Food Irradiation on Shape Rise." Food Processing, pp. 8-10.

Slate, S. C., W. A. Ross, and W. L. Partain. 1981. Reference Commercial High Level Waste Glass and Canister Definition. PNL-3838, Pacific Northwest Laboratory, Richland, Washington.

Toffer, H. and W. R. McSpadden. March 1987. Potential Production of Cobalt in $N$ Reactor. UNI-4335.

U.S. Department of Agriculture. 1989. "Use of Irradiation as a Quarantine Treatment for Fresh Fruits of Papaya from Hawaii." Federal Register. 7CFR Part 318. 387-393 (January 6, 1989).

U.S. Department of Energy. 1983. Department of Energy Plan for Recovery and Utilization of Nuclear Byproducts from Defense Waste, Executive Summary. DOE/DP-0013, August 1983, U.S. Department of Energy Assistant Secretary for Defense Programs Office of Defense Wastes and Byproducts Management. 
U.S. Department of Energy. 1986. "Trichina-Safe Pork by Gamna Irradiation Processing, A Feasibility Study." U.S. Department of Energy Byproducts Utilization Program, Washington, D.C.

U.S. Department of Health and Human Services. "Irradiation of Fresh Pork to Control Trichenella Spiralis." Federal Register. 50 CFR. 29658 (July 22, 1985).

U.S. Department of Health and Human Services. "Irradiation in the Production, Processing, and Handling of Food, Final RuTe." Federal Register. 21 CFR 179. 13376-961 (April 18, 1986).

U.S. Department of Health and Human Services. "Irradiation in the Production, Processing, and Handling of Food; Final Rule; Denial of Request for Hearing and Response to Objection." Federal Register. 21 CFR 179. 53176-209 (December 30, 1988).

Webb, T., T. Lang, and K. Tucker. 1987. Food Irradiation: tho Wants It? Thorsons Publishers, Inc., Rochester, Vermont.

WHO. 1981. "Wholesomeness of Irradiated Food," FAO/IAEA/WHO Expert Committee, WHO Technical Report Series 659, Geneva 1981.

Zurer, P. S. 1986. "Food Irradiation - A Technology at a Turning Point." Chemical and Engineering News, May 5, 1986, pp. 46-56, Washington D.C. 


\section{APPENDIX A}

AGRICULTURAL USES FOR IRRADIATION 
APPENDIX A

\section{AGRICULTURAL USES FOR IRRADIATION}

A number of engineering demonstration projects for irradiation in agricultural uses are underway, and others are at the discussion stage. Many of these efforts involve cooperation between various governmental agencies and industry. Activities and applications for radiation with ${ }^{137} \mathrm{Cs}$ are summarized in this appendix. The summary is by no means exhaustive, and additional scenarios can and should be developed to meet national and international needs. A listing of current food applications is shown in Table A.1. The terms radappertization, radicidation, and radurization all pertain to treatments that lengthen storage times and kill particular organisms, but each has a specific meaning. Radappertization is analogous to thermal sterilization (e.g., canning) and applies mostly to prepared foods. Radicidation is analogous to pasteurization with emphasis on killing nonspore-forming pathogens. Radurization is similar to radicidation except its emphasis is on delay of spoilage.

\section{IRRADIATION OF MUNICIPAL SLUDGE FOR FERTILIZER AND LIVESTOCK FEED}

With more restrictive regulations and expanding populations, the processing and disposal of municipal sewage sludge is an ever-increasing problem for many cities. Irradiation of the sludge to eliminate pathogens would convert a liability to an asset. This method would eliminate potential health risks of sewage sludge before it is applied to agricultural land or marketed to the public for general use. Two principal uses of municipal sewage sludge have been investigated: (Food Irradiation Technology in the U.S. 1982):

1) as a low-analys is fertilizer and soil conditioner and 2) as feed for livestock that would provide nitrogen, minerals, and energy (Scott 1986).

Algae produced as a byproduct of municipal waste-water treatment can be fed to cattle, swine, poultry, or fish as a quality protein supplement ("Sandia Irradiator for Dried Sewage Solids" 1978). The algae are irradiated to eliminate pathogens. In this way, irradiation permits the safe 
IABLE A.1. Selected Products Irradiated with Coba7t-60 Which Have Been Approved for Human Consumption (a)

\begin{tabular}{|c|c|c|c|}
\hline Product & $\begin{array}{c}\text { Purpose } \\
\text { of lrradiation }\end{array}$ & $\begin{array}{c}\text { Maximum } \\
\text { Dosage, krad }\end{array}$ & Countries Product Approved for \\
\hline $\begin{array}{l}\text { Shrimp }(b) \\
\text { Potatoes }\end{array}$ & $\begin{array}{l}\text { Radicidation } \\
\text { Sprout inhibition }\end{array}$ & $\begin{array}{l}600-800 \\
15\end{array}$ & $\begin{array}{l}\text { Austrialia, Netherlands USSR, Uruguay, FAO/ } \\
\text { IAEA/WHO, Netherlands, Philippines, Spain, } \\
\text { Belgium, Bulgaria, Canada, Chile, } \\
\text { Czechoslovakia, France, Hungary, Denmark, } \\
\text { Israel, Italy, Japan, Federal Republic of } \\
\text { Germany, South Africa, United States }\end{array}$ \\
\hline
\end{tabular}

Strawberries(b) Radurization 300

Onions Sprout inhibition

is

$\begin{array}{ll}\text { Garlic (b) } & \text { Sprout inhibition } \\ \text { Africa } & \\ \text { Shallots(b) } & \text { Sprout inhibition } \\ \text { Grain(b) } & \text { Insect disinfestation } \\ \text { Tonatoes } & \text { Radurization } \\ \text { Peaches(b) } & \text { Radurization } \\ \text { Apricots(b) } & \text { Radurization } \\ \text { Cherries (b) } & \text { Radurization } \\ \text { Raspberries(b) } & \text { Radurization } \\ \text { Grapes(b) } & \text { Radurization }\end{array}$

15

15

30

200

200

200

200

200

200
Belgium, Hungary, Netherlands, FAO/IAEA/WHO

Netherlands, Spain, Thialand, Belgium,

Bulgaria, Canada, USSR, Czechoslovakia,

France, Hungary, Isreal, Italy, South Africa, FAO/IAEA/WHO

Belgium, Bulgaria, France, Italy, South

Belgium, France

Butgaria, USSR

Bulgaria

Bulgaria

Bulgaria

Bulgaria

Bulgaria

Bulgaria 
IABLE A.1. (contd)

\begin{tabular}{|c|c|c|c|c|}
\hline Product & $\begin{array}{c}\text { Purpose } \\
\text { of Irradiation }\end{array}$ & $\begin{array}{c}\text { Maximum } \\
\text { Dosage, krad }\end{array}$ & \multicolumn{2}{|l|}{ Countries Product Approved for } \\
\hline $\begin{array}{l}\text { Wheat, wheat } \\
\text { flour }\end{array}$ & Insect disinfestation & 75 & Canada, RAO/IAEA/WHO, United States & \\
\hline $\begin{array}{l}\text { Spices or } \\
\text { mixed spices } \\
\text { (pepper, } \\
\text { paprika, } \\
\text { dried garlic, } \\
\text { cumin) }\end{array}$ & Radicidation & $500-3000$ & Hungary, Netherl ands, U.S.A. & \\
\hline $\begin{array}{l}\text { Pork, Cod, } \\
\text { haddock }\end{array}$ & Radurization & 150 & Canada & \\
\hline Chicken & $\begin{array}{l}\text { Radicidation and } \\
\text { radurization }\end{array}$ & $300-700$ & $\begin{array}{l}\text { Canada, Netherlands, South Africa, } \\
\text { FA0/IAEA/WHO }\end{array}$ & USSR, \\
\hline Mushrooms & Growth inhibition & 200 & Czechoslovakia, Netherlands & \\
\hline Asparagus (b) & Radurization & 200 & Netherlands & \\
\hline Cocoa beans $(b)$ & Insect disinfestation & 700 & Netherlands & \\
\hline Papayas & Radurization & $50-150$ & South Africa & \\
\hline Mangos & Radurization & $50-150$ & South Africa & \\
\hline Avacados (b) & Delayed ripening & 10 & South Africa & \\
\hline
\end{tabular}

(a) Source: $\mathrm{CH}_{2} \mathrm{M} \mathrm{Hill,} \mathrm{April} \mathrm{19-21,} 1982$ and (U.S. Department of Health and Human Services 1986).

(b) Experimental batches. Others for test marketing or unconditional acceptance by WHO. Radappertization is a high dosage (greater than 1 Mrad) for sterilization. Radurization and radicidation are medium dosages (100 Krad to $1 \mathrm{Mrad}$ ) for reaction of microbial load or extension of shelf life. 
introduction of a quality product, grown on human waste, into the human foodchain. This food conservation cycle is shown in Figure A.1. There has been interest in the effort, but implementation will depend on regulatory requirements and other institutional factors.

\section{CONTROL OF TRICHINA IN PORK}

The "trichinosis stigma" costs the U.S. pork industry substantial losses in domestic and world markets. Current research results, illustrated in Table A.2, show that irradiation at doses as low as 10 to 30 krad disinfests pork of the parasitic nematode trichinella spiralis, which is responsible for trichinosis in humans (U.S. DOE 1986; $\mathrm{CH}_{2} \mathrm{M} \mathrm{Hill} \mathrm{1982).} \mathrm{As} \mathrm{shown,} \mathrm{reproduc-}$ tion of larvae is stopped by doses as low as $10 \mathrm{krad}$. In an ongoing cooperative effort, the USDA, DOE and the pork industry are evaluating the impact of

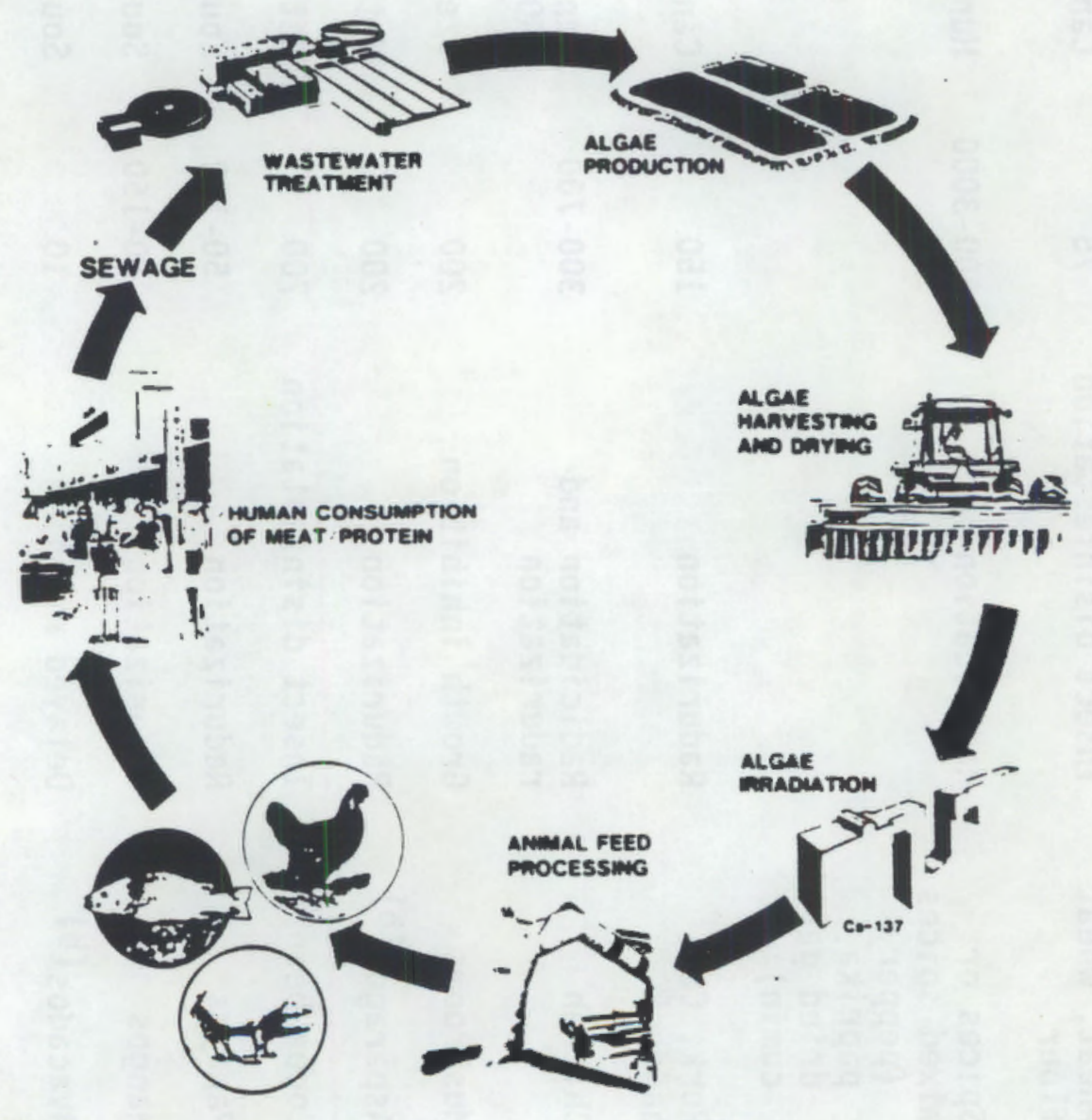

FIGURE A.1. Algae for Feedstuff Production 
TABLE A.2. Trichina Survival Data at Varying Radiation Dosage(a)

\begin{tabular}{ccr}
$\begin{array}{c}\text { Radiation } \\
\text { Dose, krad }\end{array}$ & $\begin{array}{c}\text { 5-day Adult } \\
\text { Worms, Per Rat }\end{array}$ & $\begin{array}{r}\text { Muscle Larvae, } \\
\text { Per Rat }\end{array}$ \\
\cline { 2 - 3 } & 1,800 & 325,000 \\
5 & 1,800 & 84,000 \\
10 & 900 & $<1$ \\
20 & $<1$ & 0 \\
30 & 0 & 0 \\
50 & 0 & 0
\end{tabular}

(a) Data obtained from the USDA Agricultural Research Service, Beltsville, MD.

trichinosis in the U.S. and the potential benefit to the pork program from using ${ }^{137} \mathrm{Cs}$. Existing technology is being used to demonstrate the feasibility of producing pork that is certified trichina-safe by gamma irradiation of split hog carcasses. A major step toward commercial-scale use will be the construction and testing of a demonstration-scale irradiator by the University of Iowa to establish the feasibility of the process and to obtain information required for full-scale commercial implementation. A current estimate of treatment costs are shown in Table A.3 for a 10,000 hog per day plant.

\section{DISINFESTATION OF CITRUS FRUITS}

Until recently, citrus was fumigated with ethylene dibromide (EDB) for insect disinfestation. The EPA has banned EDB from further use as of September 1, 1984. Irradiation, a viable alternative, is being investigated. Recent research on irradiation of Florida-grown grapefruit infested with Caribbean fruit fly larvae indicate that disinfestation occurs at a dose of $25 \mathrm{krad}$.

\section{CONTROL OF CODLING MOTH AND CHERRY FRUIT FLY}

Codling moths and fruit flies infest numerous agricultural crops of significant economic value. Host commodities include apples, pears, crab 
apples, quince, cherries, walnuts, and many others. High-cost pest-control measures greatly reduce the damage but cannot eliminate these pests.

Apple production in the U.S., particularly in the Pacific Northwest, is projected to increase by 40 to $60 \%$ by 1988 . Potential major markets for Northwest apples include Japan and Korea, where the codling moth does not exist. Also, cherries are marketed in these countries today, but quality is lowered by the chemicals used for disinfestation of the cherry fruit fly. Irradiation would not only improve disinfestation but would also improve the quality of the cherries because they are not degraded in the pracess.

To prevent codling moth introduction, or to prevent fruit contaminated with fruit fly from being imported, importing countries impose embargoes on host commodities such as apples and cherries. Therefore, satisfactory disinfestation procedures must be developed before these markets can be realized or expanded. Gamma irradiation with ${ }^{137} \mathrm{Cs}$ is effective as a quarantine treatment (U.S. DOE 1983). Irradiation of codling moth larvae, at dosages less than $16 \mathrm{krad}$, has been shown to prevent emergence of $99 \%$ of adult moths, and adsorbed doses of $40 \mathrm{krad}$ sterilize adult moths. Most varieties of apples tolerate doses as high as $100 \mathrm{krad}$ which permits flexibility in irradiator design. Research results for cherry fruit fly show that adult emergence can be prevented at less than $15 \mathrm{krad}$ and major pupae destruction can be obtained at below $30 \mathrm{krad}$.

\section{OTHER FRUITS AND FIELD CROPS}

Further research to verify efficacy and to quantify optimum treatment protocols and doses is needed to develop the full potential of the irradiation treatment process. An expanded research program is now under consideration. For fruits and many field crops, the dose required and any secondary effects on product quality such as texture and taste can only be tested effectively near the harvest site. Thus, a transportable irradiator has been designed and built. The design incorporates transportation of the irradiation chamber and Cs source with applications depicted in Figure A.2. 


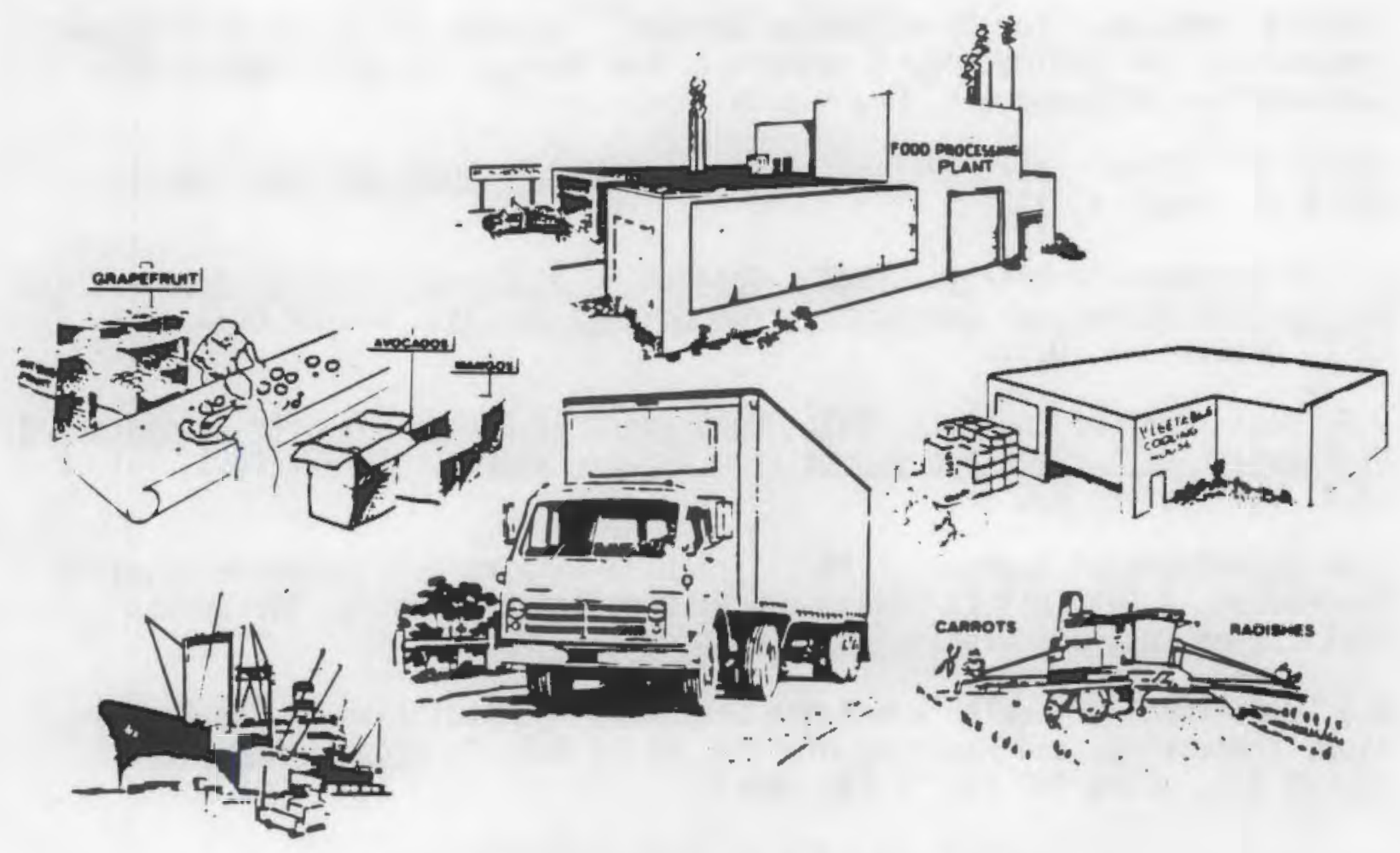

FIGURE A.2. Transportable Irradiator

\section{DISINFESTATION OF DRIED FRUITS AND TREE NUTS}

Some fumigants used in disinfestation of nuts and dried fruits leave fumigant residues that can limit the marketability of these commodities. Treatment by irradiation may aid in solving the infestation and residue problems. Pests such as the navel orange worm, codling moth, Indian meal moth, red flour beetle, and sawtoothed grain beetle are all susceptible to gamma irradiation. Fifty krads will control even the most resistant beetle species and immature stages of moths. Even lower doses $(20 \mathrm{krad})$ are expected to control reproduction and growth of young larvae. A joint industry/USDA/DOE research program is underway to examine the potential of irradiation as a treatment for raisins, prunes, walnuts, almonds and pistachios.

\section{REFERENCES}

"Food Irradiation Technology in the United States." April 19-21, 1982. Presented at the DOE/USDA/AIBS Workshop on Low-Dose Irradiation Treatment of Agricultural Commodities, Washington, D.C. 
"Sandia Irradiator for Dried Sewage Solids." October 18-19, 1978. Seminar Proceedings and Dedication, Albuquerque, New Mexico. SAND79-0182, Sandia Laboratories, Albuquerque, New Mexico.

Scott, P. 1986. "Waste Recycling the Beta-Way." South African Digest, April 25, 1986, p. 356.

U.S. Department of Energy. 1983. Department of Energy Plan for Recovery and Utilization of Nuclear Byproducts from Defense Wastes. D0E/DP-0013, Vol. 1 of 2 , Washington, D.C.

U.S. Department of Energy. 1983. Department of Energy PIan for Recovery and Utilization of Nuclear Byproducts from Defense Wastes. DOE/DP-0013, Vol. 2 of 2, Washington, D.C.

U.S. Department of Energy. 1986. "Trichina-Safe Pork by Gamma Irradiation Processing, A Feasibility Study." U.S. Department of Energy Byproducts Utilization Program, Washington, D.C.

U.S. Department of Health and Human Services. "Irradiation in the Production, Processing, and Handling of Food, Final Rule." Federal Register, 21 CFR 179, 13376-961 (April 18, 1986). 


\section{APPENDIX B}

DEMONSTRATED APPLICATIONS OF RECOVERED SPENT FUEL ISOTOPES OTHER THAN CESIUM 


\section{APPENDIX B}

\section{DEMONSTRATED APPLICATIONS OF RECOVERED SPENT FUEL ISOTOPES OTHER THAN CESIUM}

This appendix covers in greater detail than Section 6.0 the significant applications for selected isotopes recoverable from spent fuel.

Nearly 500 isotopes (or elements) are produced in nuclear reactors by fission and irradiation processes. Several of these can be considered recoverable at the present time using the following guidelines, and others may be recoverable as future conditions warrant.

The recovery of isotopes (or elements) by spent fuel treatment and their beneficial use depend on one or more of the following guidelines:

1. The isotope (or element) has a unique property that matches the requirements of a specific application.

2. The isotope (or element) is present in sufficient quantities in spent fuel.

3. Recovered isotope (or element) is marketable at an economic advantage acceptable to the producer.

4. Recovered isotope (or element) is marketable at an economic advantage acceptable to the user.

5. High value is assigned to a isotope or recovered element because the material meets a critical military or national strategic need.

6. Removal of selected isotopes or elements reduces the cost for managing the residual waste.

In Table B.1 a summary is presented of how well certain isotopes match the criteria for recovery. Americium-241 and curium-244 are not addressed in the discussion that follows because they are not recovered by the processes described in Section 5.0. 
IABLE B.1. Recovery Criteria as Applied to Recoverable Isotopes or Elements

Recover able 1sotope or Element

$\begin{aligned} & \text { Recovery Criteria } \\ & \begin{array}{l}\text { Has unique properties that } \\ \text { match specific application }\end{array}\end{aligned}$
$\begin{aligned} & \text { Sufficient quantity } \\ & \text { produced in spent fuet to } \\ & \text { justify recovery }\end{aligned}$




\section{KRYPTON: XENON, AND TRITIUM PROPERTIES ANO APPLICATIONS}

\section{Background}

Krypton-85, produced in nuclear reactors, is diluted with inert fissionproduct krypton. Krypton-85 has a haif-1ife of 10.72 years and decays to stable ${ }^{85} \mathrm{Rb}$ by emission of betas having a maximum energy of $0.687 \mathrm{MeV}$ accompanied by a low yield (0.41\%) gamma having an energy of $0.514 \mathrm{MeV}$. The heat produced by ${ }^{85} \mathrm{Kr}$ decay is $0.623 \mathrm{H}$ (watts thermal) per gram, and the specific activity is 392 curies per gram (Chart of the Nuclides 1977; Rohrmann 1968; and Rohrmann 1971). Thus $85 \mathrm{Kr}$ is a useful heat source, its beta energy can be used to produce light, and the gamma activity can be used in nondestructive testing applications (International Study of Terrestrial Applications of Radioisotopic Power Sources 1966-1967; Eggers and Gaurthrop 1975; and Rohrmann 1974).

Fission-product krypton has a yield of 27 grams of ${ }^{85} \mathrm{Kr}$ per tonne of fuel when discharged from the reactor and consists of about $7 \%{ }^{85} \mathrm{Kr}$ (Table B.2) (Rohrmann 1974; Chart of the Nuclides 1977; Rohrmann 1968). Existing fuel recovery methods reduce this concentration further because of dilution from air in leakage or air sparging during the fuel dissolution

TABLE B.2. Comparison of the lsotopic Concentration of FissionProduct and Atmospheric Krypton

\begin{tabular}{|c|c|c|c|}
\hline \multirow[b]{2}{*}{ Isotope } & \multicolumn{2}{|c|}{ Atomic \% } & \multirow{2}{*}{$\begin{array}{c}\text { Fission Product } \\
\text { Half-Life }\end{array}$} \\
\hline & Atmospheric & Fission Product (a) & \\
\hline 78 & 0.4 & - & stable \\
\hline 80 & 2.3 & -- & stable \\
\hline 81 & -- & $6.0 \times 10-6$ & $2.1 \times 105 \mathrm{yr}$ \\
\hline 82 & 11.6 & 0.3 & stable \\
\hline 83 & 11.5 & 11.2 & stable \\
\hline 84 & 56.9 & 30.8 & stable \\
\hline 85 & - & 6.1 & $10.72 \mathrm{yr}$ \\
\hline 86 & 17.3 & 51.6 & stable \\
\hline
\end{tabular}

(a) Taken from an ORIGEN code (1 yr after reactor discharge). 
step, where the krypton is released. Natural decay reduces the concentration still further. Because both the nonradioactive krypton and the $85 \mathrm{Kr}$ can be used in unique and mutually exclusive applications, it would be desirable to recover reactor produced krypton in as concentrated a form as possible and separate the isotopes as cleanly as possible by advanced isotope separation processes in the future. All the krypton produced in nuclear reactors could possibiy be used if a good recovery scheme and isotope separation of the radioactive ${ }^{85} \mathrm{Kr}$ could be achieved. Existing and proposed uses of fissionproduct krypton are discussed in the following paragraphs.

Xenon is the most abundant of all elements recoverable from spent fuel, and because all of its radioactive isotopes have very short half-lives, recovered xenon will be essentially stable one year after discharge of the spent fuel (see Table B.3).

Xenon's similarity to krypton makes it very likely that if the release of ${ }^{85} \mathrm{Kr}$ to the atmosphere is prohibited, both xenon and krypton will be recovered in the same stream. Then, because of the far greater volume of xenon, it would be separated from krypton to minimize the total volume of krypton that may have to be stored securely. Thus xenon would be obtainable

TABLE B.3. Isotopic Comparison of Fission-Product and Atmospheric Xenon

Atomic \%

\begin{tabular}{ccc} 
Isotope & Atmospheric & Fission Product (a) \\
\hline 124 & 0.096 &.- \\
126 & 0.090 & -- \\
128 & 1.92 & 0.06 \\
129 & 24.44 & 0.31 \\
130 & 4.08 & 0.23 \\
131 & 21.18 & 8.22 \\
132 & 26.89 & 20.47 \\
134 & 10.44 & 27.51 \\
136 & 8.80 & 43.19
\end{tabular}

Fission Product Half-Life

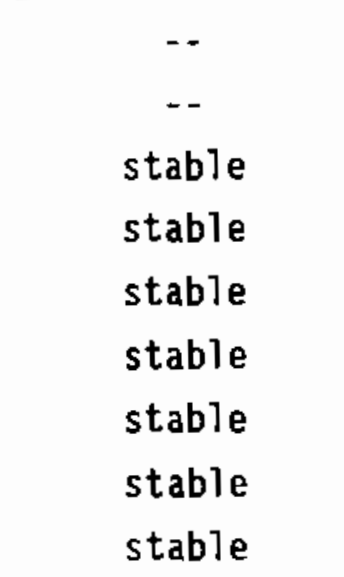

(a) Taken from an ORIGEN code (1 yr after reactor discharge). 
under very favorable economics since up to this point all processing would be required in any event just to prevent release of $85 \mathrm{Kr}$ to the environment. The only additional cost applicable to xenon would be that of refining it to an acceptably low residual ${ }^{85} \mathrm{Kr}$ content. The cryogenic processing technology to ensure such quality is available and is similar to that used in recovering xenon from air.

\section{Power Source Applications}

Krypton-85 has been proposed as an energy source for small isotopic batteries, e.g., radioisotopic thermoelectric and thermochemical generators (RTGs and RTMGs) (Tingey 1983). The Pacific Northwest Laboratory has developed a sputtering process for encapsulating fission-product krypton into a metal matrix for storage and disposal. Capsules produced by this process may be useful for making heat sources for small 1- to 2-watt RTGs for a variety of purposes if highly enriched $85 \mathrm{Kr}$ is made available. Such units would be environmentally acceptable, could be easily shielded, and would be about the size of a softball. Should the power supply be destroyed, the ${ }^{85} \mathrm{Kr}$ would dissipate to the environment with minimal hazard because krypton is not retained by biological forms. Many of the uses are similar to those described in Chapter 6 for ${ }^{90} \mathrm{Sr}$. Additional uses for $\mathrm{Kr}-85$ power units include: power supplies for biologists for tracking marine manmals, sharks, seals and large Arctic terrestrial animals; environmentally acceptable RTGs for powering remote or Arctic telephones; repeater and other civilian communications equipment; military Command, Control, Communication, and Intelligence uses and a multitude of other small 5- to 10-yr-lifetime power battery uses.

\section{Radioluminescence Applications}

The fact that radiation produced from radioisotopes can be used to excite phosphors that, in turn, emit visible light has been known for many years (Rohrmann 1974; Case and Remini 1980; Haff et al. 1981; Jensen et al. 1984a; Jensen and Leonard 1984). Beta particles (electrons) are produced by the selected isotope during its decay to form another element. These electrons strike a phosphorescent material, such as zinc sulfide, that contains a small quantity of impurity, such as copper, silver, or cadmium. The electrons are absorbed by the phosphor, and light is produced when the energy 
from this absorption is released. If an isotope is to have a practical value as an energy source for self-powered lights, it should have the following characteristics:

- a relatively long half-life

- no emission of alpha particles, neutrons, or gamina rays; or else the ability to be easily shielded

- production of a stable daughter; for example, a nonradioactive isotope

- low chemical and radiological toxicity

- modest or low cost.

Isotopes that could meet these requirements are listed in Table B.4. Krypton-85 and promethium-147 have only been used in special applications and in test situations. However, ${ }^{85} \mathrm{Kr}$ could be used if shielding requirements

IABLE B.4. Possible Isotopes for Self-Powered Illuminators and Their Relevant Properties(a)

\begin{tabular}{|c|c|c|c|c|c|}
\hline Isotope & $\begin{array}{l}\text { Half- } \\
\text { Life } \\
\text { (yr) }\end{array}$ & $\begin{array}{l}\text { Maximum } \\
\text { Beta } \\
\text { Energy } \\
\text { (MeV) } \\
\end{array}$ & $\begin{array}{l}\text { Shielding } \\
\text { Required } \\
\end{array}$ & $\begin{array}{l}\text { Radiological } \\
\text { Toxicity }\end{array}$ & Remarks \\
\hline Tritium & 12.4 & 0.018 & ni] & very low & $\begin{array}{l}\text { Low energy. Low cost. } \\
\text { Easy to handle. No } \\
\text { shielding beyond contain- } \\
\text { ment required. }\end{array}$ \\
\hline $\begin{array}{l}\text { Promethium- } \\
147\end{array}$ & 2.6 & 0.23 & 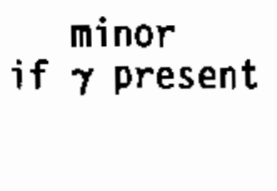 & medium & $\begin{array}{l}\text { Expensiye Short halff- } \\
\text { life. }{ }^{4} \mathrm{P}_{\mathrm{Pm}} \text { and } 148 \mathrm{Pm}_{\mathrm{m}}, \\
\text { which emit gamma rays, } \\
\text { may be present. }\end{array}$ \\
\hline Krypton-85 & 10.7 & 0.67 & moderate & low & $\begin{array}{l}\text { Inert gas. Some shield- } \\
\text { ing required. More } \\
\text { expensive than tritium or } \\
\text { promethium. Encapsula- } \\
\text { tion can discolor because } \\
\text { of radiation. }\end{array}$ \\
\hline
\end{tabular}

(a) Reference: Jensen et al. 1984a. 
were met, supplies were adequate and the prices were right. The energy contained in the beta particle emitted from $85 \mathrm{Kr}$ decay may be an advantage in producing a more intense light.

Application and engineering development needs for lights powered by $85 \mathrm{Kr}$ require satisfying a supply-demand situation, improving the phosphors, design and testing for specific applications, and meeting the institutional and societal requirements such as licensing.

Tritium meets all of the above requirements and is, therefore, used in a variety of commercially available products in various applications. Tritium gas can be encapsulated in a glass tube or container coated on the inside with a zinc sulfide phosphor. Uses for this type of light source include exit and other self-powered warning signs for buildings, aircraft, and light standards in the photographic industry. For example, lights containing from 4 to 30 curies of tritium have been used on commercial aircraft and in public buildings in emergency exit signs since the mid-1960s (Wilson and Hughes 1960; Neimeyer 1970). The primary advantages of radioluminescent (RL) lighting are:

- It requires no external source of power, thus it is not subject to power failure or interruption.

- It does not burn out or require wiring, thus the units are selfcontained and maintenance is minimal.

- Where temporary or emergency lighting is required, supply problems from the need to replace components with short shelf lives, such as batteries, are reduced.

- RL lighting can function under many severe environmental conditions such as temperatures below $-70^{\circ} \mathrm{F}$.

The applications for these lights discussed in the following section are not exhaustive, but they do identify the wide range of possible uses for this technology.

\section{Runway Lighting and Marking}

Self-powered radioluminescent lights have been manufactured and demonstrated for runway, taxiway, heliports, threshold, visual approach slope indicator 1 anding and marking purposes for both fixed-wing and rotary-wing aircraft. For military purposes the lights can be designed to be 
transportable, rugged, and easily installed. They would be employed to locate drop zones and for remote or temporary runway lighting to meet rapid runway repair or other tactical uses. In the civilian sector the need and application is characterized by observing that there are over 700 airfields in Alaska. Most are for fixed-wing, land-based aircraft; however, some are used for rotorcraft and seaplanes. Only 10\% of these runways have lighting. The Civil Aeronautics Board has classified 410 U.S. airfields as Essential Air Service fields. Over half of these are in Alaska and only 27 of these are lighted. The Alaska State Department of Transportation and Pubiic Facilities is chartered to identify means to reduce the number of unlighted airports to meet safety, emergency, and other remote A]askan needs (Jensen et al. 1984a). Lighting of the remaining airfields will be costly by conventional means; self-powered lights can offer a lower capital cost alternative and are being evaluated for this purpose. They also have the advantage that they do not significantly affect night vision during landing or other nighttime operations, will lose only half their intensity in 10 to 12 years, and should have a low maintenance and operation cost.

\section{Marine Navigational Aids}

Self-powered lights also can be used as channel markers, for navigational aids and buoy lighting, underwater marking, and other marine purposes. Currentiy, electrically (battery or generators) powered lights are used, but batteries must be replaced regularly, generators must be fueled and in many situations this is dangerous and expensive. In addition, some needed navigational lighting is not in place because the means for conveniently supplying power or servicing the site are not available. Self-powered lights using either tritium and ${ }^{85} \mathrm{Kr}$ could meet the needs of these applications if the installations are properly designed. Since the intensity will approximate the half-life of the isotope used, i.e., 10 to 12 years for ${ }^{85} \mathrm{Kr}$ or tritium, the only cost will be for the lights and the scheduled replacement to maintain the needed visibility criteria. This application should increase the safe use of our waterways.

Roadway Lighting. Safety Lighting and Other Uses

Tritium lights have been used many years for safety lighting, exit signs in aircraft and buildings, and aircraft and other instrument lighting. For 
example, tritium-illuminated phosphors are used in exit signs in aircraft to indicate location of doors and in watch faces or instruments to allow night visibility. These sorts of uses could be expanded with a larger supply of tritium or an available supply of $85 \mathrm{kr}$. Another use of the lights would be for remote highway lighting and marking, e.g., curve warning and bridges. In these applications, ${ }^{85} \mathrm{Kr}$ could be used if the installation is properly designed. The reduction in costs for this purpose could be significant and would add to the safety of highway travel. Military applications are numerous and include flashlights, route markers, escape illumination, runway sighting markers and many other uses.

\section{Nondestructive Testing}

Nondestructive testing applications of ${ }^{85} \mathrm{Kr}$ are primarily for flaw detection in metals and electronic components, gauging, leak detection, sensing and position indicating (Eggers and Gaurthrop 1975; NTIAC 1978). Some of these are reasonably well developed, e.g., flaw detection, leak detection and gauging, while others are not as well developed. Kryptonation, the process normally used for flaw detection, involves impregnating a material or component with $85 \mathrm{Kr}$. Krypton-85 can be forced into a material by pressurization. Surface condition (wear patterns and flaws such as microcracks) can be identified with good sensitivity. Radiographic techniques are used to locate the effects and measure their severity. This method has been used for detection of cracks in gas turbine and aircraft turbine blades.

Krypton-85 has also found 7 imited use as a leak detector to guarantee the integrity of hermetically sealed containers. Sensitivity and economy are the major advantages of these tests. Components are soaked in ${ }^{85} \mathrm{Kr}$ gas at approximately seven atmospheres for 2 to 16 hours. Leaky components will partially fill with ${ }^{85} \mathrm{Kr}$ gas during the soak. The krypton gas in the chamber is then recovered, and the exterior of the component is cleaned by partial vacuum. The ${ }^{85} \mathrm{Kr}$ in leaking components can then be measured by scintillation counting.

Gauging applications are straightforward and use the beta energy for measuring thickness and weight. Krypton-85 sources are self-contained and are unaffected by temperature and humidity. Both backscatter- and transmission-type systems are used to measure thickness or weight of material 
passing the detector. Transmission gauges are used in the paper, plastics and rubber industries, employing sources containing from $500 \mathrm{mCi}$ to a few curies of ${ }^{85} \mathrm{Kr}$ per source.

Nonradioactive Fission-Product Krypton and Xenon

Krypton and xenon gas are used for filling fluorescent and incandescent lights, where its thermal and chemical properties are superior to the alternatives, nitrogen or argon (Shreve and Aust in 1984). This is a major use for natural krypton. Krypton and xenon gas are al so used in instrumentation and for research applications. Since natural krypton and xenon are usually scarce, the nonradioactive fraction of both fission-product gases could be used for existing applications if they could be separated at high purity from the radioactive $85 \mathrm{Kr}$.

\section{Xenon in Medicine}

Xenon-oxygen mixtures were demonstrated as an anesthetic (Cullen and Gross 1951) over 30 years ago. Several experiments were completed on human subjects to identify pain thresholds using xenon-oxygen and nitrous oxideoxygen mixtures. The results were favorable, especially the rapid recovery from anesthesia (patients were orjented within 5 minutes). Thus xenon, if available in quantity, could be a widely used anesthetic for many surgical procedures. In particular, it might be valuable as a battlefieid anesthetic, where extremely rapid recovery without residual effects is desirable.

\section{Other Applications of Xenon}

When the electronic structure of xenon is exited by a high voltage, it produces a spectrum that is used in laser applications. It also serves as a filler gas in the $x$-ray tube, where its thermal properties help extend the life of the device (Shreve and Austin 1984). Xenon is employed in instrumentation and research applications. Xenon also forms compounds with other elements. For example, the use of xenon fluoride compounds as fluorinating agents in pharmaceutical manufacturing has been proposed (Kirk-0thmer 1980).

\section{Projected Xenon and Krypton Prices}

The prices of the rare gases krypton and xenon as commercially obtained from liquid air processes are about $\$ 0.65$ per liter (STP) for krypton and 
about $\$ 4.00$ per liter for xenon, each for orders of one thousand liters or more. An Exxon study (Rohrmann 1968) indicated that, if obtained from spent fuel, the selling price for krypton (including al1 the ${ }^{85} \mathrm{Kr}$ ) would be about $\$ 31.00$ per liter but only about $\$ 0.42$ per liter for xenon. The reason for this great difference relates to the fact that krypton removal during fuel processing is required to isolate the radioactive ${ }^{85} \mathrm{Kr}$ and that essentially all the costs are thus borne by the need for the krypton processing. Xenon costs therefore relate to hardly more than the load-out costs. It appears then that fission product xenon could be available at a price near, if not less than, the current price of krypton obtainable from atmospheric resources (Rohrmann 1983). Furthermore, the quantities of fission product xenon that could be made available from reprocessing would be equivalent to that for krypton from current commercial atmospheric resources. World-wide, the availability of xenon is in the range of a few hundred thousand liters annually and for krypton it is in the range of a few million liters.

\section{STRONTIUM-90 APPLICATIONS}

Strontium-90 is about 55\% of strontium produced by nuclear fission and about $1-2 \%$ of the fission products produced. It has a half-life of 28.8 years and decays by beta emission to yttrium-90, which has a half-life of only 64 hours. Yttrium-90 decays by beta emission to stable ${ }^{90} \mathrm{Zr}$. Both decays are accompanied by significant gamma from bremsstrahlung conversion. The ${ }^{90} \mathrm{Sr}$ maximum energy is a modest $0.55 \mathrm{MeV}$, but the ${ }^{90} \mathrm{Y}$ maximum energy is $2.27 \mathrm{MeV}$ and requires heavy shielding. The decay sequence yields $0.93 \mathrm{~W}_{\mathrm{t}}$ (watts thermal) per gram of ${ }^{90} \mathrm{Sr}$ (Chart of the Nuclides 1977; "Characteristics of Radioisotopic Heat Sources 1973 ) $17 \%$ of which is from the ${ }^{90} \mathrm{Sr}$ decay and $83 \%$ from the $90 \mathrm{Y}$ decay (International Study of Terrestrial Applications of Radioisotopic Power Sources" 1966-1967; and Rohrmann 1968). Thus ${ }^{90} \mathrm{Sr}$ with its short half- life daughter is an excellent energy source. Technology for its recovery and conversion to useful chemical forms is well established.

When discharged from a nuclear reactor, the ratio of the ${ }^{90} \mathrm{Sr}$ to strontium is in the range of 0.55 to 0.62 (gram per gram). Nonradioactive strontium fission-product isotopes and any natural strontium introduced during chemical processing steps dilute the desired isotope and thus reduce the heat 
output per gram of the product strontium. The ${ }^{90} \mathrm{Sr}$ content is further reduced by the natural decay process; thus, in time the product can become so dilute that too little heat is produced to be usable in most applications. Existing designs for power-generation equipment require a minimum $90 \mathrm{Sr} / \mathrm{Sr}$ ratio of 0.4 or greater at the start of life, but some thermal applications may use material with a ratio of 0.3 under special conditions (International Study 1966-67; Rohrmann 1968, 1971; "Characteristics of Radioisotopic Heat Sources" 1973).

\section{Power Source Applications}

Strontium-90 has been used as the energy source for over 60 RTGs used in terrestrial applications. Strontium-90 has been investigated as the energy source for Rankine, Brayton and Stirling cycle engines, and for thermionic converters (Advanced Energy Programs 1977). Past activities in developing applications have concentrated on exploiting the high reliability of thermoelectric generators. New developments in long-life, high-performance Stirling engines (Cook-Yarborough 1982; Sternlicht 1983) indicate that advantage can be taken of their much higher conversion efficiency (25 to $40 \%$ compared with 5 to $8 \%$ for RTGs) in many of these same applications.

Early RTGs used $\mathrm{SrTiO}_{3}$ or $\mathrm{Sr}_{2} \mathrm{TiO}_{4}$ as the fue? form, but more recent designs have used $\mathrm{SrF}_{2}$. Failures are rare and manufacturers report over 5,000,000 $\mathrm{h}$ of successful operation, according to Teledyne Energy Systems, Inc. These devices require no maintenance, are not affected by climatic conditions or electromagnetic shock, and can be designed to resist natural or man-directed destructive forces. Discussion of specific applications of this technology using ${ }^{90} \mathrm{Sr}$ follows.

\section{Remote Weather Stations}

Strontium-90-powered RTGs were used during the 1960s to power remote weather stations at Axe] Heiberg Island in the Canadian Arctic and at other locations (International Study of Terrestrial Applications of Radioisotopic Power Sources 1966-1967; Perrigo 1976; U.S. Congress, House 1981). The packages used consisted of the RTG and a data telemetry package in various configurations suited to the particular applications. 
The weather station at Axel Heiberg operated from August 1961 through August 1963 (International Study of Terrestrial Applications of Radioisotopic Power Sources 1966-1967). The strontium-powered RTG operated reliably throughout the life of the station, but failures in the electronics and meteorological sensors occurred. RTG's were also used to power weather station equipment at the McMurdo Sound, Antarctica, and for Navy Oceanographic and Meteorological Automatic Devices (NOMAD) barge-type weather stations. Many of these units are still in use in similar power applications.

Command, Control, Communications and Intelligence $\left(C^{3} I\right)$

As most $C^{3} I$ equipment systems powered by RTGs are classified, details concerning their use are unavailabie. Power requirements have ranged from 1 to $100 \mathrm{We}$, and these RTGs have operated reliably for as long as 15 years in these applications. No failures of the power systems have been reported. RTGs in $C^{3} I$ applications have the advantages that they are not affected by the electromagnetic pulse from a nuclear explosion and they can be hardened to withstand blast effects.

As mentioned, single units having $100-W_{e}$ electrical power capacities have been built. The extension of existing technology to $500-W_{e}$ units and the use of multiple units to provide higher power outputs is expected to be achievable. Features of this type of power system include: demonstrated Arctic compatibility, minimal developmental cost, heat for thermal conditioning, continuous infrared signature, nondestructible in fire, beneficial use of reactor byproduct, and highest reliability at lowest maintenance.

Remote Surveillance Station

RTGs have been used to power surveillance equipment at remote locations. The most notable of these is the installation at Fairway Rock, Alaska, where the Navy has powered surveillance equipment from August 1966 through May 1981 (Hickock et al. 1981) using a single Sentinel 25A RTG. The unit was then replaced with two Sentinel $25 \mathrm{~s}$ to provide increased power because the power output of the former unit was near the minimum needed to operate the electronic equipment. The original RTG required no maintenance or fuel during 
its entire usable life and was retained on Faimay Rock as a spare. Total operating time on this unit approached $130,000 \mathrm{~h}$ of continuous, re1iable operation without failure.

\section{Navigational Aids}

Many marine navigational aids require power levels in the range of 10 to $100 \mathrm{We}$ (International Study of Terrestrial Applications of Radioisotopic Power Sources 1966-1967). RTGs have been demonstrated for 1ighting systems in Chesapeake Bay, in Sweden, and the United Kingdom. Proposed and demonstrated uses include underwater navigation beacons, surface channel markers, buoys and other navigational aids for inaccessible locations. The SNAP-25 series RTG manufactured by Teledyne Energy Systems was in fact designed for deep-sea (up to 8000 psi) operations.

RTGs have also been proposed for powering both civilian and military aircraft navigational aids. Many of these applications require remote, very reliable, low-maintenance power for their operation, and isotopic power sources can effectively meet these needs.

\section{Remote Emergency Power}

In most remote locations of human habitation, conventional diesel electric or gas turbine power generating equipment is used to supply power for lighting, communications, and other life-support uses. A failure of the main power source can be disastrous for a population if the unit cannot be repaired and communications are lost unjess another source of power is available. This power source does not have to be large, just sufficient to operate a radio, perhaps power a few lights, and supply enough power to keep essential life-support control systems in operation and some heat to keep people from freezing. A properly designed RTG system, if available, could meet many of these requirements.

\section{Heat Source Applications}

Properly encapsulated and shielded, ${ }^{90}$ Sr could be used for heat sources for Arctic, petroleum and military applications (Perrigo 1976; U.S. Congress, House 1981). Heater sizes would be comparable to those needed as energy sources for RTG applications. Thus, power sources recovered from used RTGs or ${ }^{90} \mathrm{Sr}$ that is unacceptable as an RTG fuel might be used for heater 
applications. Specific criteria for these uses will be application-dependent, but most will relate to thermal need, reliability, and life-cycle requirements. In the following sections, several of these possibilities are discussed. Further refinement, applications engineering, and adaptation will be required to use "isotope" heat in these applications.

\section{Arctic Sewage Treatment Heaters}

In the Arctic, sewage is usually collected by "honeybuckets" and/or sewage tank trucks and carried to a central location for disposal. Normally the disposal site is a pond, tank, or other holding area that is exposed to the environment and remains frozen during the long Arctic winter. Digestion and further treatment occurs only during the short summer or by use of expensive, energy-intensive sewage treatment facilities when and where available. Because the digestion process is dormant when sewage is frozen, large volumes of sewage are poorly treated and the potential for disease and pollution is high. The problem could be alleviated by using ${ }^{90}$ Sr heaters in specially designed digesters to keep the sewage from freezing and permit continuous digestion year-round. Fluid circulation in the digester could be produced by designing the heater blocks as thermosyphons to perform the required pumping. The result would be a self-powered unit operating for 10 to 15 years without refueling--a substantial savings in fuel oil.

\section{Arctic Utilidore, Water Distribution System or Sewage Collection System} Heaters

Utilidores are insulated and heated conduits that contain utility piping (sewage, potable water, power cables), and connect these services between Arctic housing and a central sewage, water treatment or power facility. Existing systems use electric heaters wound around the piping for heating, and thermal differences within the utilidore can vary as much as $35^{\circ} \mathrm{F}$.

Where utilidores are not used, potable water is delivered by truck, and sewage is collected in honeybucket trucks. A few locations have small potable water distribution systems or sewage collection systems, but freezing is a chronic problem and reliable heaters are needed to ensure that the system works. Fire control systems are nonexistent because of the problem of freezing. 
Use of isotopic heat produced by ${ }^{90} \mathrm{Sr}$ heat sources would be a reliable and low-maintenance alternative to existing methods for keeping water distribution and sewage collection systems from freezing. The sources would be placed at appropriate intervals in utilidores or piping systems to provide the needed heat lost to the environment. Proper design of the piping and its insulation could minimize the number of sources and still meet the heat loads required.

\section{Heaters for Petroleum Tanks and Collection Systems}

Heaters for petroleum tanks and collection systems are similar to those described in the previous section for Arctic water and sewage system heaters. In addition, ${ }^{90} \mathrm{Sr}$ heaters installed in tanks in cold locations would keep the oil warm and pumpable using thermosyphon principles.

\section{Downhole Heaters for Enhanced 0il Recovery}

Currently $48 \%$ of the oil produced in the U.S. is recovered by primary methods; $48 \%$ is recovered by a secondary method, water injection; and the remainder by other enhancement recovery methods (DOE Report Examines Enhanced 017 Recovery Constraints" 1980). Thermal stimulation using steam and electrical heat, an alternative method, has limited value because of technical limitations and cost. Conventional bottom-hole heaters produce about $70,000 \mathrm{Btu}$, or $20.5 \mathrm{kWt}$, and are technically and economically usable only at depths less than $5000 \mathrm{ft}$.

Encapsulated ${ }^{90} \mathrm{Sr}$ could be placed at the bottom of the hole and the decay heat used to stimulate production (Perrigo 1976). If the well failed prior to the decay of the ${ }^{90} \mathrm{Sr}$ source reaching nonproductive levels, the source could be moved to another well and continued to be used. Because heat sources used for this purpose could be used for at least two half-lives, well stimulation is a viable option provided capsule integrity is sufficient. Use of the method is independent of well depth, and retrieval is possible with current well drilling and operating technology. At present, a limited amount of proprietary work has been done on these concepts. 


\section{NOBLE METALS APPLICATIONS}

The following sections discuss applications for ruthenium, rhodium, palladium, and technetium.

\section{Ruthenium}

Ruthenium is one of the rarest of the natural platinum group metals (Jensen et al. 1984b). It is also potentially the most useful. Concentrations contained in spent nuclear fuel are 300 to 500 times higher than those found in natural deposits. Ruthenium metal is extremely refractory and hard and is an excellent catalyst. Increased uses could be reasonably anticipated as the availability of ruthenium is increased by recovery from nuclear waste (Jensen et al. 1984b).

Fission-product ruthenium contains several stable isotopes plus the radioactive isotopes $\mathrm{Ru}-103\left(\mathrm{t}_{1 / 2}=39\right.$ days) and $\mathrm{Ru}-106\left(\mathrm{~T}_{1 / 2}=367\right.$ days $)$. Both radioisotopes are present in freshly discharged fuel in very high activity levels, but ${ }^{103} \mathrm{Ru}$ decays to undetectable levels in about three years. Because of the longer half-life, at least 30 years are required before the ${ }^{106} \mathrm{Ru}$ decays to concentrations that permit unrestricted use.

Ruthenium-106 controls the beneficial use of inert fission-product ruthenium and, through possible cross-contamination, al so affects the beneficial use of fission-product rhodium and palladium as well. Ru-106 decays by beta emission to Rh-106 $\left(t_{1 / 2}=30 \mathrm{~s}\right)$, which decays by beta emission to stable ${ }^{106}$ Pd. This decay chain mandates complete separation of ruthenium from rhodium and palladium to avoid compromising their radiochemical properties.

The specific power of ${ }^{106} \mathrm{Ru}$ is 33.1 watts per gram; thus if it were separated by isotope separation processes, it might be used as a power or heat source in metallic form in applications that were described earlier for ${ }^{85} \mathrm{Kr}$ and ${ }^{90} \mathrm{Sr}$. When the heat source reaches its end of life, the pure stable palladium would be recovered and any ${ }^{106} \mathrm{Ru}$ would be recycled.

Rhodium

Fission-product rhodium is almost entirely stable ${ }^{103} \mathrm{Rh}$, with only trace amounts of the radioisotopes $102 m_{R h}\left(t_{1 / 2}=206\right.$ days $)$ and ${ }^{102} R h\left(t_{1 / 2}=\right.$ 
2.9 years). Two other radioisotopes, $103 \mathrm{~m}_{\mathrm{Rh}}$ and $106 \mathrm{Rh}$, are present from the decay of fission-product ruthenium but decay to undetectable levels in the rhodium in a few days after separation from ruthenium (Rohrmann 1971).

Rhodium-102 and $102 \mathrm{~m}_{\mathrm{Rh}}$ are present in freshly discharged fuel in low concentrations: up to about 2600 and $400 \mu \mathrm{Ci}$ per gram of rhodium, respectively (Jensen et a1. 1984b). Because of its longer half-life and gamma decay activity, ${ }^{102} \mathrm{Rh}$ has the major effect on beneficial use of fission-product rhodium that has been adequately separated from ruthenium. A decay time of 35 years would reduce the activity to approximately $0.6 \mu \mathrm{Ci} / \mathrm{g}$ of rhodium.

Fission-product rhodium has been alloyed with platinum for use as the catalyst for manufacture of nitric acid. Tests in an Engelhard Industries pilot $\mathrm{plant}$ were completed with no detectable carry-over of catalyst activity into the product stream and good conversion characteristics.

\section{Palladium}

Fission-product palladium consists of several stable isotopes and the radioisotope ${ }^{107} \mathrm{Pd}$. Palladium-107 is a very low-energy beta emitter with a half-life of $6.5 \times 10^{6}$ years. Depending on reactor conditions, fissionproduct palladium will contain 80 to $100 \mathrm{\mu Ci}$ of this isotope per gram and the activity is essentially constant because of the long half-life. The surface dose rate of highly purified fission-product palladium was measured and found to be $0.8 \mathrm{r} / \mathrm{h}$ (Roberts 1972). Human skin will totally absorb it. Fortunately, the range of the beta is only $4 \mathrm{mg} / \mathrm{cm}^{2}$ and is easily shielded. Almost any kind of gloves will shield workers from external radiation from fissionproduct palladium. Internal deposition characteristics must be identified for fission-product palladium.

\section{Technetium}

The only available supply of technetium is as a fission product in spent nuclear reactor fuel, where it occurs in quantities approaching 800 grams per tonne of heavy metal in spent power reactor fuel (Jensen et al. 1984b). Fission-product technetium is essentially all ${ }^{99} \mathrm{Tc}$, a long-lived $(2.1 \times$ $10^{5}$ year) weak beta emitter $(0.292 \mathrm{MeV})$. The beta activity is quite high, about $0.02 \mathrm{Ci} / \mathrm{g}$, and is essentially constant because of the long half-life. This activity must be considered in a11 technetium applications. 
Information available on the properties and use of technetium is limited, making verification and further developments necessary if its unique properties are to be utilized. It has shown promise as a catalyst in reforming gasoline and in other chemical reactions, where it could replace platinum, palladium or rhodium, and as a corrosion inhibitor or an antifouling agent for surfaces exposed in marine environments. It could aiso replace the rare and costly rhenium in some alloys and catalytic applications (Jensen 1984b). Brief discussions on these uses follow.

\section{Iechnetium Catalysts}

Technetium was evaluated as a catalyst for organic reactions in the early 1970s in laboratory- and bench-scale experiments (Blackham and Palmer 1970; Palmer 1974). Catalysts were prepared by impregnating alumina with ammonium pertechnetate solutions and then reducing the pertechnetate with hydrogen. The catalysts proved effective for converting $n$-heptane to toluene at $500^{\circ} \mathrm{C}$ and were thus effective in dehydrogenation and ring formation reactions similar to those that are used in producing gasoline. A significant factor was the tolerance of the catalyst to sulfur. This property could be useful in the development of catalysts for fuel cells where sulfur tolerance has been a severe limitation. Mercaptan or other organic sulfur had only minimal effect on the catalyst activity. The catalyst was easily regenerated.

Because it could possibly be an alternative for platinum as a catalyst in many organic reactions, technetium should be evaluated further for possible classification as a strategic material (FEMA 1980; Jensen et al. 1984b).

\section{Iechnetium as a Corrosion Inhibitor}

The superior effectiveness of the pertechnetate ion as a corrosion inhibitor was identified in early 1952. Subsequent work throughout the intervening period has given rise to many theoretical studies concerning the mechanisms displayed by inorganic inhibitors in preventing corrosion (Cartledge 1966a; 1966b; 197I; 1973; Burns and Leitz 1953). In a11 these studies the superior effectiveness of the pertechnetate ion as a corrosion inhibitor in aqueous solutions was identified. Pertechnetate concentrations 
ranged from 1 to $10 \mathrm{ppm}$ in these studies, and corrosion inhibition was believed to be related to passivation of the metal surface by a thin layer of pertechnetate ion.

A 20-yr corrosion inhibition experiment was performed when a carbon steel coupon was placed in an aqueous solution containing $10 \mathrm{ppm}$ chloride and $5 \times 10^{-4}$ molar $\mathrm{KTCO}_{4}$. A control coupon was placed in distilled water. After 13 years the coupon in the pertechnetate solution had no weight loss, the solution was clear, and the metal looked new. The control was badly corroded and the solution was murky. Similar short-term tests at ambient and higher temperatures have given comparable results.

Unfortunately, the work to date, although promising, is not definitive. More work is necessary to identify and take advantage of the corrosionprevention properties of this unique metal. For example, in addition to its use as an additive as described above, it might be alloyed in metals to give superior corrosion resistance and strength.

\section{Technetium as a Coating to Prevent Biofouling}

Buildup of biota is often a major contributor to the malfunction of equipment exposed in marine environments, and its prevention is paramount to successful use of optical systems, heat transfer surfaces, rack and pinion controls, and other operating equipment. Several patents exist that indicate technetium prevents organisms from attaching to these surfaces. However, there is little technical literature on the use of technetiun for this purpose. A definitive study is needed. The use of technetium in coatings or alloys needs to be explored and tested, particularly for naval and other military applications.

\section{PLUTONIUM-238 AND NEPTUNIUM-237 APPLICATIONS}

These two isotopes are discussed together because ${ }^{237} \mathrm{~Np}$ is the precursor of ${ }^{238} \mathrm{Pu}$, which is useful as a source of heat and power (Figure B.I). Neptunium-237 has been routinely recovered, exposed to neutrons and converted to 238pu. Plutonium-238 is an alpha emitter, having a half-life of 87.7 years. It produces $0.56 w_{t}$ per gram and requires minimum shielding. 


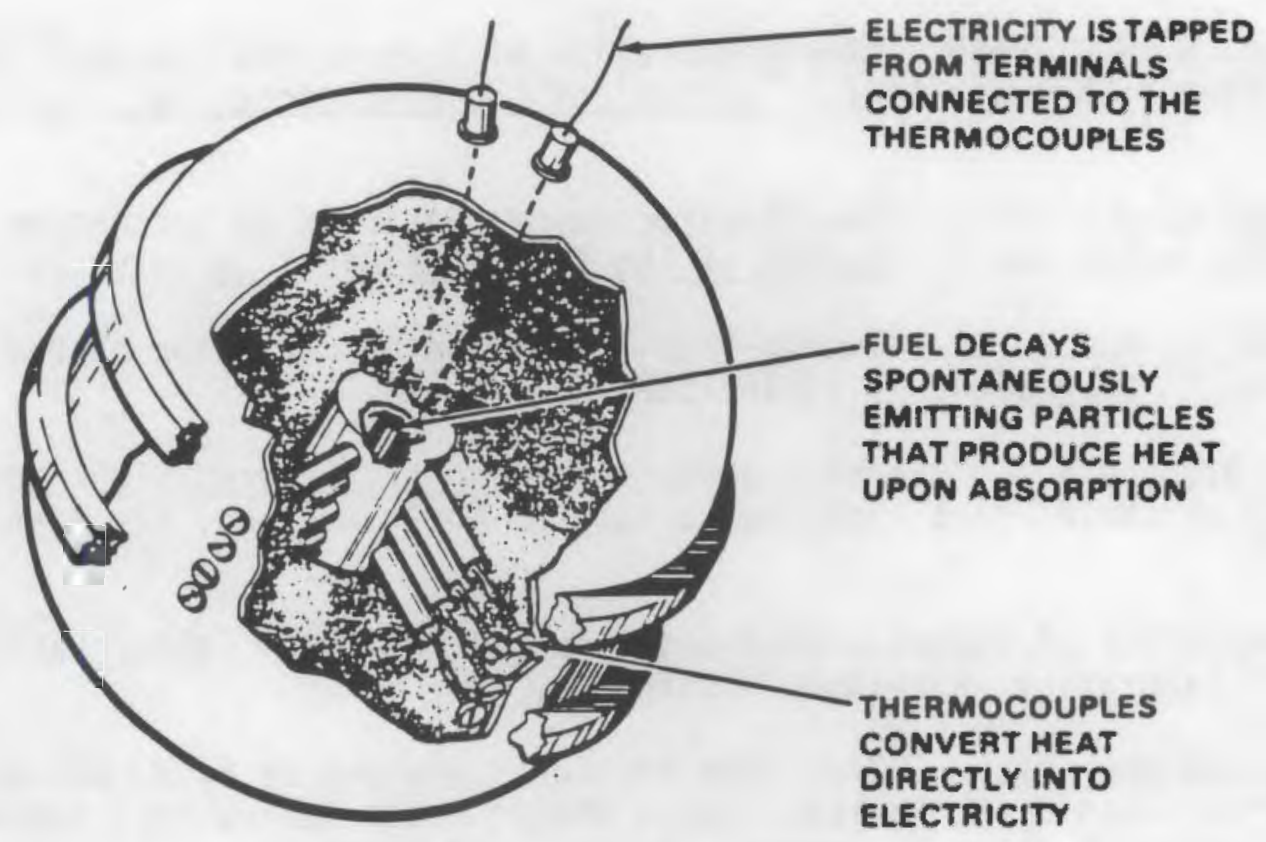

FIGURE B.1. Plutonium-Powered RTG

Space nuclear power systems, using plutonium, have been highly reliable, providing up to 500 watts of continuous, stable direct current to spacecraft used in NASA and DOD space missions. Missions to the planets would have been impossible without such heat and power sources.

Plutonium-238 has also been used in miniature RTGs for heart pacemakers and could be used as a power source for heart pumps and prosthetic devices if such devices become feasible. Additional possibilities exist and are similar to those described earlier under strontium.

\section{REFERENCES}

Advanced Energy Programs. 1977. Final Report $-2 \mathrm{~kW}(e)$ Unattended Power System Study. 77SES-4230, Space Division, General Electric Company.

Bl ackham, A. U., and J. L. Palmer. 1970. Technetium as a Catalyst in Organic Reactions, Final Report. RLO-2017-3, Brigham Young University, Provo, Utah.

Burns, R. E., and F. J. Leitz. 1953. Iechnetium as a Corrosion Inhibitor. HW-28727, Hanford Works Report.

Cartledge, G. H. 1966a. "The Mechanism of the Action of Inorganic Inhibitors." British Corrosion Journal, 1:294-302. 
Cartledge, G. H. 1966b. "The Passivation of Iron in the Presence of Pertechnetate and Chromate Ions." Journal of the Electrochemical Society, $\underline{113}(4)$.

Cartledge, G. H. 1971. "The Electrochemical Behavior of Technetium and Iron Containing Technetium." Journal of the Electrochemical Society, 118(11).

Cartledge, G. H. 1973. "Twenty-Year Inhibition of Corrosion by the Pertechnetate Ion." Corrosion, 29(1):361-362.

Case, F. N., and W. C. Remini. 1980. Radioisotope-Powered Light Sources.

Presented at the Airport Lighting Society of North America, Key West,

Florida.

"Characteristics of Radioisotopic Heat Sources." 1973. Table, Pacific Northwest Laboratory, Richland, Washington.

Chart of the Nuclides. 1977. 12th Edition. Revised by F. W. Walker, G. J. Kirouac and F. M. Rourke, Knolls Atomic Power Laboratory, Schenectady, New York, General Electric Company, San Jose, California.

Cook-Yarborough, E. H. March 25-26, 1982. "Diaphragm Stirling Engines: Achievements and Future Potential." Stirling Engines - Progress Towards Reality, University of Reading I Mech. E. 1982-2, pp. 49-56.

Cullen, S. C., and E. G. Gross. 1951. "The Anesthetic Properties of Xenon in Animals and Human Beings, with Additional Observations on Krypton." Science, $\underline{113}: 580-582$.

"DOE Report Examines Enhanced 0il Recovery Constraints." 1980. 0i1 and GaS Journal, p. 106.

Eggers, P. E., and W. E. Gaurthrop. 1975. An Assessment of the Potentially Beneficial Uses of Krypton-85. BMI-X-660, Battelle Memorial Institute, Columbus, Ohio.

FEMA. 1980. Stockpile Report to the Congress, October 1980-March 1980. Federal Emergency Management Agency, P\&P-1, pp. 23-24.

Haff, K. W., F. J. Schultz, F. N. Case and J. A. Tompkins, 1981. Testing of Tritium-Powered Runway Distance and Taxiway Markers. ESL-TR-81-45, Engineering and Services Laboratory, Air Force Engineering and Services Center, Tyndall Air Force Base, Florida.

Hickock, G., G. Weller, T. N. Davis, V. Alexander and R. Elsner. 1981. United States Arctic Science Policy. Alaska Division, American Association for the Advancement of Science, P. 33.

"International Study of Terrestrial Applications of Radioisotopic Power Sources." 1966-1967. Isotopes and Radiation Technology, 4 (2):172-182. 
Jensen, G. A., L. D. Perrigo, L. E. Leonard, and L. Hegdal . 1984a. Examination of the Feasibility for Demonstration and Use of Radioluminescent Lights for Alaskan Remote Runway Lighting. PNL-5183 (AK-RD-84-16), Pacific Northwest Laboratory, Richland, Washington.

Jensen, G. A., et a1. 1984b. "Recovery of Noble Metals from Fission Products." Nuclear Technology, 65:305-324.

Jensen, G. A. and L. E. Leonard. November 1984. Radioluminescent Lighting for Rural Alaskan Runway Lighting and Marking. PNL-SA-12723, Pacific Northwest Laboratory, Richland, Washington.

Kirk-0thmer. 1980. "Hydrogen-Ion Activity to Laminated Materials, G1ass." Encyclopedia of Chemical Technology, 3rd Edition, Vol. 13, John WiTey \& Sons, New York.

Niemeyer, R. A. 1970. "Tritium Loss from Tritium Self-Luminous Aircraft Exit Signs," Isotopes and Radiation Technology, I(3):349-352.

NTIAC. 1978. "Krypton Exposure Technique." NTIAC Newsletter, Nondestructive Testing Information Analys is Center, Department of Defense.

Palmer, J. L. 1974. Part 1. Catalytic Hydrocarbon Reforming by Technetium Catalysts. Part II. Acetone Azine and 3,5,5-Trimethy 7-2-pyrazol ine Adducts of Palladium Chloride. Dissertation, Department of Chemistry, Brigham Young University, Provo, Utah.

Perrigo, L. D. 1976. Cold Regions Isotope Applications. BNWL-1935, Pacific Northwest Laboratory, Richland, Washington.

Roberts, F. P. 1972. The Radiation Characteristics of Reactor Produced Rhodium, Palladium, Ruthenium and Technetium. BNWL-1693, Pacific Northwest Laboratory, Richland, Washington.

Rohrmann, C. A. 1968. "Values in Spent Fuel from Power Reactors." In Isotopes and Radiation Technology, 6(1):19-4l, Oak Ridge National Laboratory, Oak Ridge, Tennessee.

Rohrmann, C. A. 1971. "The Availability and Applications of Radioactive and Stable By-Products from the Chemical Processing of Spent Nuclear Power

Fuels." In Proceedings of the 10th Conference on Radioisotopes, Japan Atomic Industrial Forum, Inc., pp. 57-68.

Rohrmann, C. A. 1974. "Fission-Product Xenon and Krypton--An Opportunity for Large Scale Utilization." Isotopes and Radiation Technology, $\underline{8}(3): 253$.

Rohrmann, C. A. 1983. "The Potential for Large Scale Uses for Fission Product Xenon." Waste Management, Vol. II, p. 81 .

Shreve, R., and G. T. Austin. 1984. Chemical Process Industries. McGrawHill Book Company. 
Sternlicht, B. 1983. "Rebirth of the Stirling Engineer." Chemtech, pp. 28-36, New York.

Tingey, G. L. 1983. "The Potential for Beneficial Use of Krypton-85." Waste Management, Vol. II, p. 89.

U.S. Congress, House. 1981. Beneficial Uses of Defense Nuclear Materials Byproducts. Heating before the Procurement and Military Nuclear Systems Subcomittee of the Committee of Armed Services, House of Representatives, Ninety-Seventh Congress, First Session, March 5, 1981, pp. 154, 205-208, U.S. Government Printing Office, Washington, D.C.

Wilson, E. J., J. D. H. Hughes. 1960. "Light Sources Using Radioisotopes." Contemporary Phys, 1(1):62-69. 
APPENDIX C

CALCULATIONS OF THE POTENTIAL AND ACCUMULATED INVENTORY OF GAMMA SOURCES 
APPENDIX C

\section{CALCULATIONS OF THE POTENTIAL AND ACCUMULATED INVENTORY OF GAMMA SOURCES}

This appendix provides additional details on the calculation of potential needs for gamma source materials and the alternatives for supplying those needs. The results are shown in Tables C.l through C.4. In Table C.1, which projects the minimum availability of gamma source material, the assumption is that minimum growth will occur in the supply of gamma source materials. In the table, cobalt production is the annual production. In the minimum case the cobalt production is from the Advanced Test Reactor (ATR) near Idaho Falls, which has a nominal capacity of $1 \mathrm{MCi} /$ year. Cobalt imports are the annual anticipated imports from Canada and, as noted in the footnote, are limited to $50 \%$ of the Canadian production capacity or to 20 MCi. Cobalt decay is calculated as $15 \%$ of the previous year's inventory to account for residual curries in material removed from the irradiation facilities. Cobalt inventory is the total inventory for that year. The total inventory results from the previous year's inventory minus decay plus imports and production. No cesium production is anticipated in the minimum case. Cesium is decayed at a rate of $2.5 \%$ of the previous year's inventory, which is al so higher than the actual decay rate to account for some removal at the end of the capsule iife. Cesium inventory is the total cesium present for that year and results from the previous year's inventory plus production minus decay. The total inventory is the sum of the cobalt inventory and $1 / 7$ of the cesium inventory to account for WESF capsules and the difference in effectiveness of the two isotopes and their capsules.

Table C.2 is intended to provide an upper estimate of the production possible from several al ternatives and is constructed in a similar manner to Table C.I except that 4 MCi of additional cobalt production is included for U.S. reactors and could include ATR, FFTF, N-Reactor, and commercial power reactors. Importing of cobalt is limited to $50 \mathrm{MCi}$, which is about $50 \%$ of the potential Canadian production in 1996. Further increases were not included. With the higher production and imports, the total cobalt inventory 
TABLE_.1. Predicted Gamma Source Inventory with Minimum Production

\begin{tabular}{|c|c|c|c|c|c|c|c|c|}
\hline Yeer & $\begin{array}{l}\text { Cobalt } \\
\text { Production, } \\
\text { nei }\end{array}$ & $\begin{array}{l}\text { Cobatt } \\
\text { Imports, } \\
\text { NCi } \\
\end{array}$ & $\begin{array}{l}\text { Cobait } \\
\text { Decay, } \\
\text { Mci } \\
\end{array}$ & $\begin{array}{c}\text { Cobalt } \\
\text { Inventory, } \\
\text { mei } \\
\end{array}$ & $\begin{array}{l}\text { Cesium } \\
\text { Production, } \\
\text { mci } \\
\end{array}$ & $\begin{array}{l}\text { Cesium } \\
\text { Decey, } \\
\text { Mci } \\
\end{array}$ & $\begin{array}{c}\text { Ces ivm } \\
\text { Inventory, } \\
\text { mci }\end{array}$ & $\begin{array}{c}\text { Total } \\
\text { Imventory } \\
\text { As } \\
\text { MCI } \\
\end{array}$ \\
\hline $\begin{array}{l}1986 \\
1987 \\
1988 \\
1989 \\
1990 \\
1991 \\
1992 \\
1993 \\
1994 \\
1995 \\
1996 \\
1997 \\
1998 \\
1999 \\
2000 \\
2001 \\
2002 \\
2003 \\
2004 \\
2005\end{array}$ & 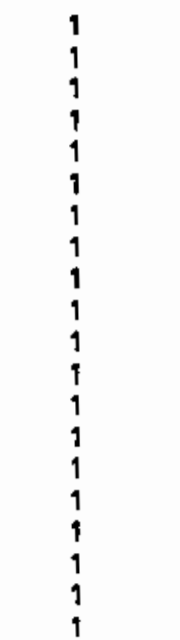 & $\begin{array}{l}14 \\
16 \\
19 \\
20 \\
20 \\
20 \\
20 \\
20 \\
20 \\
20 \\
20 \\
20 \\
20 \\
20 \\
20 \\
20 \\
20 \\
20 \\
20 \\
20\end{array}$ & $\begin{array}{r}0 \\
9 \\
10 \\
12 \\
13 \\
14 \\
15 \\
16 \\
17 \\
18 \\
18 \\
19 \\
19 \\
19 \\
19 \\
20 \\
20 \\
20 \\
20 \\
20\end{array}$ & $\begin{array}{c}62 \\
70 \\
79 \\
88 \\
96 \\
103 \\
108 \\
113 \\
117 \\
121 \\
123 \\
126 \\
128 \\
130 \\
131 \\
133 \\
134 \\
135 \\
135 \\
136\end{array}$ & $\begin{array}{l}0 \\
0 \\
0 \\
0 \\
0 \\
0 \\
0 \\
0 \\
0 \\
0 \\
0 \\
0 \\
0 \\
0 \\
0 \\
0 \\
0 \\
0 \\
0 \\
0 \\
0 \\
0\end{array}$ & $\begin{array}{l}0 \\
1 \\
1 \\
1 \\
1 \\
1 \\
1 \\
1 \\
1 \\
1 \\
1 \\
1 \\
1 \\
1 \\
1 \\
1 \\
1 \\
1 \\
1\end{array}$ & $\begin{array}{l}34 \\
33 \\
32 \\
32 \\
31 \\
30 \\
29 \\
28 \\
28 \\
27 \\
26 \\
26 \\
25 \\
24 \\
24 \\
23 \\
23 \\
22 \\
22 \\
21\end{array}$ & $\begin{array}{c}67 \\
74 \\
84 \\
94 \\
109 \\
108 \\
114 \\
118 \\
123 \\
126 \\
129 \\
131 \\
133 \\
135 \\
136 \\
137 \\
138 \\
139 \\
140 \\
140\end{array}$ \\
\hline
\end{tabular}

Assumptions:

- Cobalt imports are 50\% of AECL praduction capacity or $20 \mathrm{MCi}$, whichever is less.

- No additional cobalt is produced in FFTF.

- Mo cesium is processed from defense wastes.

- Current cesium curies are valued at $1 / 7$ of cobalt curies. 


\section{IABLE C.2. Predicted Gamma Source Inventory in the United States with}

Maximum Production

\begin{tabular}{|c|c|c|c|c|c|c|c|c|}
\hline Year & $\begin{array}{l}\text { Cobalt } \\
\text { Production, } \\
\text { Mci }\end{array}$ & $\begin{array}{l}\text { Cobalt } \\
\text { Imports, } \\
\text { MCi } \\
\end{array}$ & $\begin{array}{l}\text { Cobelt } \\
\text { Decay, } \\
\text { MCi } \\
\end{array}$ & $\begin{array}{c}\text { Cobolt } \\
\text { Inventory, } \\
\text { Mij } \\
\end{array}$ & $\begin{array}{c}\text { Cesium } \\
\text { Proctuction, } \\
\text { MCi } \\
\end{array}$ & $\begin{array}{l}\text { Cesiun } \\
\text { Decoy, } \\
\mathrm{MCi} \\
\end{array}$ & $\begin{array}{c}\text { Cesium } \\
\text { Imvertory. } \\
\text { MCi }\end{array}$ & $\begin{array}{c}\text { Totel } \\
\text { Inventory } \\
\text { As } \\
\text { MCi } \\
\end{array}$ \\
\hline $\begin{array}{l}1986 \\
1987 \\
1988 \\
1989 \\
1990 \\
1991 \\
1992 \\
1993 \\
1994 \\
1995 \\
1996 \\
1997 \\
1998 \\
1999 \\
2000 \\
2001 \\
2002 \\
2003 \\
2004 \\
2005\end{array}$ & $\begin{array}{l}1 \\
1 \\
1 \\
5 \\
5 \\
5 \\
5 \\
5 \\
5 \\
5 \\
5 \\
5 \\
5 \\
5 \\
5 \\
5 \\
5 \\
5 \\
5 \\
5\end{array}$ & $\begin{array}{l}14 \\
16 \\
19 \\
24 \\
29 \\
31 \\
32 \\
35 \\
39 \\
46 \\
50 \\
50 \\
50 \\
50 \\
50 \\
50 \\
50 \\
50 \\
50 \\
50\end{array}$ & $\begin{array}{r}0 \\
9 \\
10 \\
12 \\
14 \\
17 \\
20 \\
23 \\
25 \\
28 \\
32 \\
35 \\
38 \\
41 \\
43 \\
45 \\
46 \\
47 \\
49 \\
50\end{array}$ & $\begin{array}{r}62 \\
70 \\
79 \\
96 \\
116 \\
135 \\
151 \\
168 \\
187 \\
210 \\
234 \\
254 \\
271 \\
285 \\
297 \\
308 \\
317 \\
324 \\
330 \\
336\end{array}$ & $\begin{array}{r}0 \\
0 \\
0 \\
20 \\
20 \\
20 \\
20 \\
20 \\
20 \\
20 \\
20 \\
15 \\
15 \\
225 \\
215 \\
210 \\
210 \\
210 \\
210 \\
210\end{array}$ & $\begin{array}{l}0 \\
1 \\
1 \\
1 \\
1 \\
2 \\
2 \\
3 \\
3 \\
4 \\
4 \\
4 \\
5 \\
5 \\
10 \\
15 \\
20 \\
25 \\
30 \\
34\end{array}$ & $\begin{array}{r}34 \\
33 \\
32 \\
52 \\
70 \\
88 \\
106 \\
124 \\
141 \\
157 \\
173 \\
184 \\
194 \\
414 \\
619 \\
813 \\
1003 \\
1188 \\
1368 \\
1544\end{array}$ & $\begin{array}{c}67 \\
74 \\
84 \\
105 \\
128 \\
149 \\
171 \\
191 \\
215 \\
242 \\
268 \\
290 \\
309 \\
368 \\
421 \\
470 \\
517 \\
562 \\
604 \\
645\end{array}$ \\
\hline
\end{tabular}

Assumptions:

- Cobalt imports are 50X of AECL production capacity based on fraiser (1985) but are limited to $50 \mathrm{MCi}$.

- FFTF/M Reactor production of $2 \mathrm{MCi} / \mathrm{Yr}$ starts in 1989 along with $2 \mathrm{MCi} / \mathrm{yr}$ from unidentified sources.

- The $250 \mathrm{mCi}$ of cesium in defense wastes are made available begiming in 1987.

- Current cesium curies are rated at $1 / 7$ of cobalt curies, and future cesium curies are valued at $1 / 5$ of cobalt curies.

- Reprocessing of spent fuel begins in 1999 and provides $210 \mathrm{mci} / \mathrm{Yr}$ thereafter. 
TABLE C.3. Predicted Gamna Source Inventory with Maximum Development of Resources and No Imports After 1999

\begin{tabular}{|c|c|c|c|c|c|c|c|c|}
\hline Year & $\begin{array}{c}\text { Cobalt } \\
\text { Procuction, } \\
\text { MCi }\end{array}$ & $\begin{array}{l}\text { Cobolt } \\
\text { Imports, } \\
\text { Mci } \\
\end{array}$ & $\begin{array}{l}\text { Cobalt } \\
\text { Decay, } \\
\text { HCi } \\
\end{array}$ & $\begin{array}{c}\text { Cobalt } \\
\text { Imventory, } \\
\text { Mci }\end{array}$ & $\begin{array}{c}\text { Cesium } \\
\text { Production, } \\
\text { Mci }\end{array}$ & $\begin{array}{l}\text { Cesium } \\
\text { Decay, } \\
\mathrm{MCi}\end{array}$ & $\begin{array}{c}\text { Cesium } \\
\text { Inventory, } \\
\text { MCi } \\
\end{array}$ & $\begin{array}{c}\text { Total } \\
\text { Inventory } \\
\text { As } \\
\text { MCi } \\
\end{array}$ \\
\hline 1986 & 1 & 14 & 0 & 62 & 0 & 0 & 34 & 67 \\
\hline 1987 & 1 & 16 & 9 & 70 & 0 & $i$ & 33 & 74 \\
\hline 1988 & 1 & 19 & 10 & 79 & 0 & 1 & 32 & 84 \\
\hline 1989 & 5 & 24 & 12 & 96 & 20 & $i$ & 52 & 105 \\
\hline 1990 & 5 & $\mathbf{x}$ & 14 & 116 & 20 & $\uparrow$ & 70 & 128 \\
\hline 1991 & 5 & 31 & 17 & 135 & 20 & 2 & 88 & 148 \\
\hline 1992 & 5 & 32 & 20 & 151 & 20 & 2 & 106 & 171 \\
\hline 1993 & 5 & 35 & 23 & 169 & 20 & 3 & 124 & 199 \\
\hline 1994 & 5 & 39 & 25 & 187 & 20 & 3 & 341 & 215 \\
\hline 1995 & 5 & 46 & 28 & 210 & 20 & 4 & 157 & 242 \\
\hline 1996 & 5 & 50 & 32 & 234 & 20 & 4 & 173 & 268 \\
\hline 1997 & 5 & 50 & 35 & 254 & 15 & 4 & 184 & 290 \\
\hline 1998 & 5 & 50 & 38 & 271 & 15 & 5 & 194 & 309 \\
\hline 9999 & 5 & 0 & 41 & 235 & 225 & 5 & 414 & 318 \\
\hline 2000 & 5 & 0 & 35 & 205 & 215 & 10 & 619 & 329 \\
\hline 2001 & 5 & 0 & 31 & 179 & 210 & 15 & 813 & 342 \\
\hline 2002 & 5 & 0 & 27 & 157 & 230 & 20 & 1003 & 358 \\
\hline 2003 & 5 & 0 & 24 & 139 & 210 & 25 & 1188 & 376 \\
\hline 2004 & 5 & 0 & 21 & 123 & 210 & 30 & 1368 & $3 \%$ \\
\hline 2005 & 5 & 0 & 18 & 109 & 210 & 36 & 1544 & 418 \\
\hline
\end{tabular}

Assumptions:

- Cobalt inparts are 50\% of AECL production cepecity besed on fraiser (1985) but are limited to 50 MCì.

- FFTF production of 2 MCi/yr starts in 1989 along with 2 MCi/yr from unidentified sources.

- The $250 \mathrm{MCi}$ of cesium in defense wastes are made available begiming in 7987.

- Current cesium curies are rated at $1 / 7$ of cobalt curies, and future cesium curies are valued at $1 / 5$ of cobalt curies. 
TABLE C.4. Predicted ${ }^{60} \mathrm{C}_{0}$ Gamma Source Required for Medical and Food Treatment

\begin{tabular}{|c|c|c|c|c|}
\hline Year & $\begin{array}{l}\text { Projected Minimum } \\
\text { Gamma Requirement } \\
\text { (MCi) } \\
\end{array}$ & $\begin{array}{l}\text { Gamma Required } \\
\text { for Medical } \\
\text { Commercial (MCi) }\end{array}$ & $\begin{array}{l}\text { Gamma Required } \\
\text { for Food (MCi) }\end{array}$ & $\begin{array}{l}\text { Projected Maximum } \\
\text { Gamma Requirement } \\
\text { (MC } i) \\
\end{array}$ \\
\hline 1986 & 67 & 65 & 2.0 & 67 \\
\hline 1987 & 75 & 72 & 3.2 & 75 \\
\hline 1988 & 84 & 79 & 5.1 & 84 \\
\hline 1989 & 96 & 88 & 8.2 & 96 \\
\hline 1990 & 110 & 97 & 13.1 & 110 \\
\hline 1991 & 116 & 107 & 19.7 & 127 \\
\hline 1992 & 122 & 118 & 29.5 & 148 \\
\hline 1993 & 128 & 131 & 41.3 & 172 \\
\hline 1994 & 134 & 144 & 57.8 & 202 \\
\hline 1995 & 141 & 160 & 72.3 & 232 \\
\hline 1996 & 148 & 176 & 75.9 & 252 \\
\hline 1997 & 155 & 195 & 79.7 & 275 \\
\hline 1998 & 163 & 205 & 83.6 & 288 \\
\hline 1999 & 171 & 215 & 87.8 & 303 \\
\hline 2000 & 180 & 226 & 92.2 & 318 \\
\hline 2001 & 189 & 237 & 96.8 & 334 \\
\hline 2002 & 198 & 249 & 101.7 & 350 \\
\hline 2003 & 208 & 261 & 106.8 & 368 \\
\hline 2004 & 218 & 274 & 112.1 & 386 \\
\hline 2005 & 230 & 288 & 117.7 & 406 \\
\hline
\end{tabular}


is much higher than in the minimum case. Cesium production is assumed from the Hanford and Savannah River defense wastes. These sources provide $20 \mathrm{MCi}$ of cesium annually through 1996 and then decrease to $15 \mathrm{MCi}$ through 1999. Reprocessing of commercial spent fuel provides $210 \mathrm{MCi} / \mathrm{yr}$ starting in 1999 and continues each year thereafter. With new capsule designs, ${ }^{137} \mathrm{Cs}$ curies are assumed to be one-fifth as effective as ${ }^{60}$ Co curies. Table C.2 indicates that major amounts of both cobalt and cesium may be available in the later years.

Table C.3 is constructed similar to Table C.2, with the major exception of stopping imports of cobalt starting in 1999. With lower amounts of cobalt entering the system, it can be noted that the total cobalt inventory drops rapidly, and the majority of the gamma inventory is present as cesium in 2005.

Table C. 4 provides the estimates of gamma source requirement in MCi of ${ }^{60} \mathrm{co}$ for irradiation treatment. Both the minimum and maximum projections are based on the use of $110 \mathrm{MCi}$ in 1990. For the minimum projection, the growth beyond 1990 is a simple compound growth of $5 \%$ annually. For the maximum growth projection, the increase in medical products is separated from the growth for treatment of food. The estimate of the required gamma inventory for medical products is based on an estimate of $10.5 \%$ annual growth until $90 \%$ of the medical products are treated, which is expected to occur in about 1996, with subsequent growth 7 imited to $5 \%$ annually. The growth in inventory needed to support food irradiation is based on a $2 \mathrm{MCi}$ current inventory, which grows at a $60 \%$ rate for 1987 and 1988, at 50\% in 1989, 1990, and 1991, at $40 \%$ annually from 1992 to 1994 , and at $25 \%$ in 1995 to reach the estimate of $75 \mathrm{MC} i$ inventory for food treatment in 1996. It then continues to grow at $5 \%$ thereafter. The difference in the two estimates can be noted and approaches a factor of two by 2005 . 


\section{DISIRIBUTION}

No.. of

Copies

OFFSITE

10 DOE Technical Information Center

3 DOE Albuquerque Operations Office

P.0. Box 5400

Albuquerque, NM 87185

ATTN: R. L. Holton

P. A. Saxman

C. B. Quinn

3 DOE Office of Defense Waste \& Byproducts

Washington, DC 20545

ATTN: J. E. Lyt Te, DP-12

G. H. DaTy

S. P. J. Mathur

DOE Office of Energy Research Human Health and Assessments

Washington, DC 20545

ATTN: J. N. Maddox

3 DOE Office of Terminal Haste Disposal \& Remedial Action Washington, DC 20545

ATTN: J. E. Baublitz

R. B. Chitwood

J. A. Coleman, NE-24

DOE Savannah River Operations Office

P.0. Box A

Aiken, SC 29801

Attn: G. K. Oertel

2 Environmental Protection Agency

Office of Radiation Programs

401 J Street, S.W.

Washington, DC 20460

ATTN: D. Egan

G. L. Sjoblom
No. of

Copies

3 Oak Ridge National Laboratory

P.0. Box X

Oak Ridge, TN 37830

ATTN: K. W. Haff

F. J. Schultz

J. Setaro

R. D. Jarrett

U.S. Department of Agriculture Room 226, B-001

BARC-WEST

Beltsville, MD 20705

J. Ayer

U.S. Nuclear Regulatory Commission

Mait Stop SS-396

Washington, DC 20555

M. J. Bell

Division of Nuclear Materials Safety \& Safeguards

Mail Station 881-SS

U.S. Nuclear Regulatory Commission

Washington, DC 20555

A. T. Clark

Division of Fuel Material Safety

U.S. Nuclear Regulatory Commission

Washington, DC 20555

J. S. Sivinski

$\mathrm{CH}_{2} \mathrm{M}-\mathrm{Hi} 11$

6121 Indian School Rd NE

A7buquerque, NM 87110

S. B. Ahlstrom

$\mathrm{CH}_{2} \mathrm{M}-\mathrm{Hill}$

5995 S. Syracuse St.

Englewood, co 80111 
No. of

Copies

Technical Library

Battelle Memorial Institute

$505 \mathrm{King}$ Avenue

Columbus, $\mathrm{OH} 43201$

W. R. McDonnell

E. I. du Pont de Nemours Company

Savannah River Laboratory

Aiken, SC 29801

R. G. Post

College of Engineering

University of Arizona

Tucson, AZ 85721

D. J. Sasmor

Sandia National Laboratories

Division 6453

Albuquerque, NM B7185

Martin Stein

Precision Materials Corp.

Replogle Avenue

Mine Hi11, NJ 07081

G. R. Dietz

Isomedix, Inc.

11 Apollo Dr.

Whippany, NJ 07981

John Parker

International Nutronics, Inc. 1000 Elwell Court, Suite 232

Palo Alto, CA 94303

Alan Chin

Radiation Sterilizers

3000 Sand Hill Road

Bldg. 4, Suite 245

Menlow Park, CA 94025

Lawrence Barrett

Applied Radiant Energy Corp.

2432 Lakeside Dr.

Lynchburg, VA 804-525-5252
No. of

Copies

G. F. Linkous

Teledyne Energy Systems

$110 \mathrm{~W}$. Timonium Road

Timonium, MD 21093-3163

Shelly Peterson

3M Company

Surgical Products Division

601-22nd Ave. South

Brookings, SD 47006

Mr. Felix, Romeo

Becton Dickinson

I Becton Dr.

Franklin Lakes, NJ 07417-1880

Kent Robinson, President

IOTECH, Inc.

11080 Irma

Northglenn, CO 80233

Mr. J. Ransohoff

Neutron Products, Inc.

P.0. Box 95

Dickerson, MD 20753

P. Baker

American Pharmaseal

1 Butterfield Trail

El Paso, TX 79906

John Soluion

Cobe Laboratories

1185 Oak St.

Lakewood, CO 80215

Bihar Gidwani CSA

Kidder, Peabody \& Co.

10 Hanover Sq. 16th Floor

New York, NY 10005

Leroy Capper

Travenol Laboratories, Inc.

P.0. Box 490

Round Lake, IL 60073 
No. of

Copies

Don Price

Sherwood Medical

183101 ive St.

St. Louis, MO 63103

Jeff Beck

Johnson and Johnson

Sterilization Sciences Group

Ethicon, Inc.

Somerville, NJ 08876

George Sadek

Radiation Technology, Inc.

108 Lake Denmark Road

Rockaway, NJ 07866

Jack Young

IRT Corp.

P.0. Box 85317

San Diego, CA

Or. D. W. Tedder

School of Chemical Engineering Georgia Institute of Technology Atlanta, GA 30332-0100

G. Subbaraman

Applied Nuclear Research

Rockwell International

6633 Canoga Ave.

Canoga Park, CA 91303

Dixy Lee Ray

Fox Island, WA 98333

Richard Boehling

Virginia Power \& Light

P.0. Box 402

Minera7, VA 23117

G. P. Dix

$X$ Corporation

26619 Haney Avenue

Damascus, MD 20872
No. of

Copies

Stuart L. Iverson

Atomic Energy of Canada Limited Research Company

Pinawa, Manitoba

Canada ROE ILO

\section{FORE IGN}

D. L. Beaulieu

Nordion International Inc.

447 March Road

P.0. Box 13500

Kanata, Ontario

Canada K2K 1X8

A. Jeffs

Ontario Hydro

700 University Avenue, C27E1

Toronto, Ontario

Canada H5G $1 \times 6$

\section{ONSITE}

6 OOE Richland Operations Office

R. B. Goranson

J. R. Hunter

D. K. Jones

G. W. Rosenwald

J. J. Sutey

J. D. White

7 Westinghouse Hanford Company

S. 0. Atkin

H. R. Brager

R. W. Powe11

I. E. Reep

R. E. Schenter

H. Toffer

B. D. Zimmerman 
No. of

Copies

45 Pacific Northwest Laboratory

C. R. Allen

G. H. Bryan

M. D. Brown

H. C. Burkholder

L. L. Clark

D. A. Dingee

T. E. Devine

D. E. Eakin

J. K. Gower

P. E. Hart

R. F. Hazelton

D. K. Hilliard

J. N. Holloway

J. H. Jarrett (5)

G. A. Jensen
No. of

Copies

Pacific Northwest Laboratory (contd)

Y. B. Katayama

D. E. Knowiton

L. G. Morgan

J. L. McElroy

R. W. McKee

A. M. Platt

A. W. Pritchard

H. A. Ross (10)

G. L. Tingey

E. J. Wheelwright

M. K. White

Publishing Coordination

Technical Report Files (5) 